Universidad de Lima

Facultad de Derecho

Carrera de Derecho

\title{
"DE LA CONFEDERACIÓN GERMÁNICA AL II REICH, EL ORIGEN POLÍTICO DEL DERECHO DE INTEGRACIÓN"
}

Tesis para optar por el Título Profesional de Abogado.

Manuel Valega Mires

Código 20071933

Asesor

Josef Zielinski Flores

Lima - Perú

Mayo de 2018 


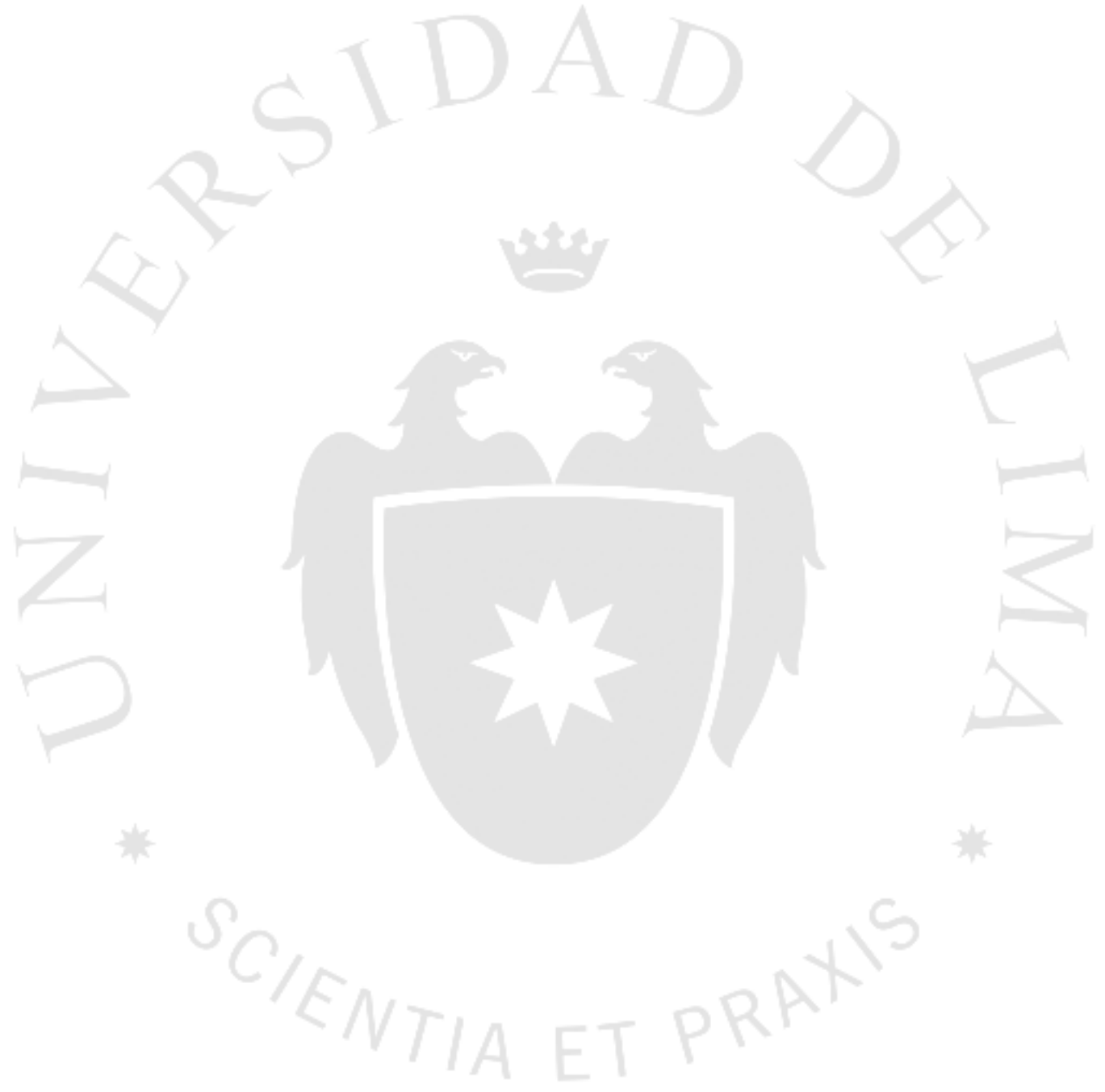




\section{"DE LA CONFEDERACIÓN GERMÁNICA AL II REICH, EL ORIGEN POLÍTICO DEL DERECHO DE INTEGRACIÓN"}


A mi hija Raffaella y a mi abuela, mis dos grandes tesoros.

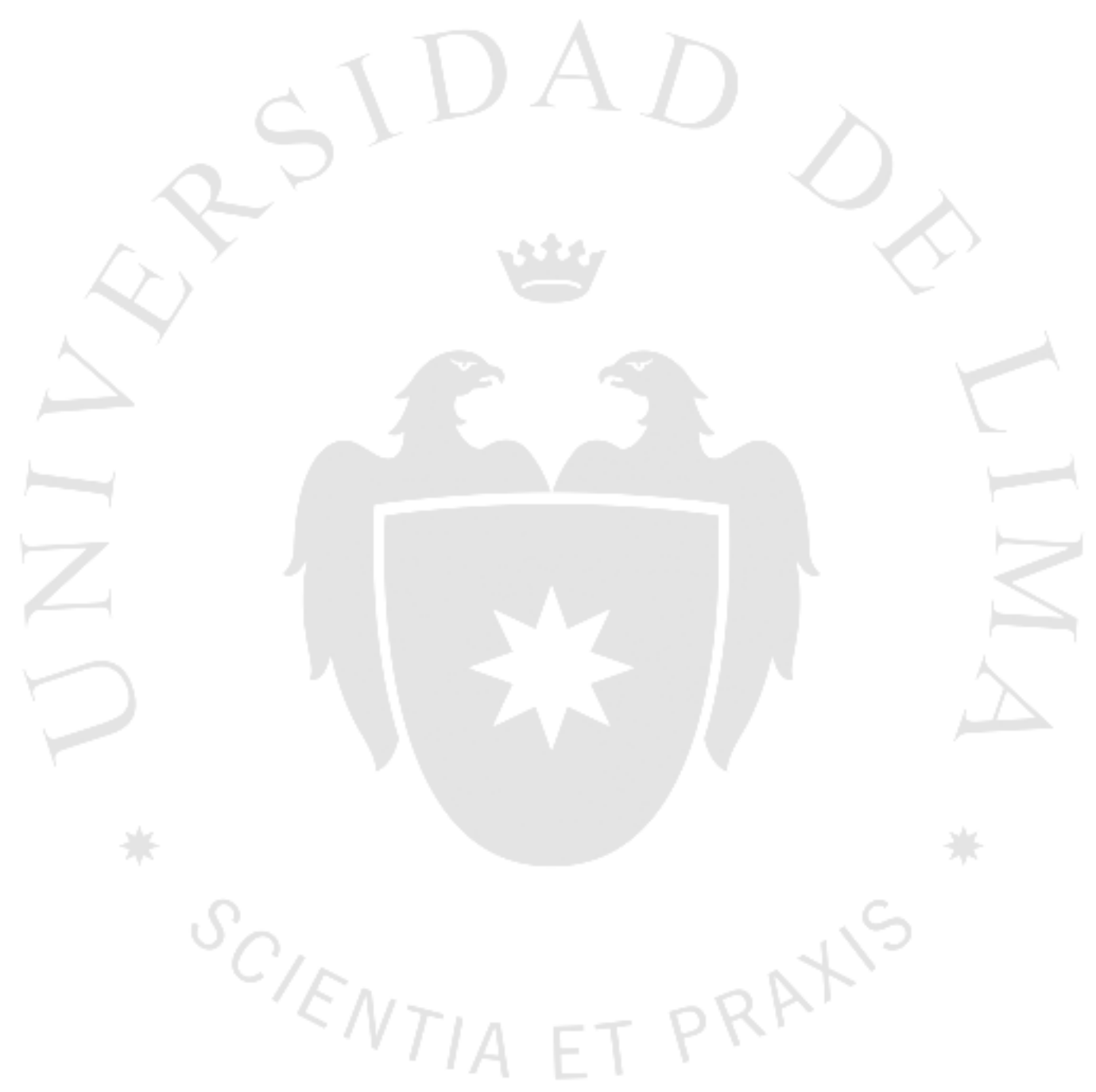




\section{TABLA DE CONTENIDO}

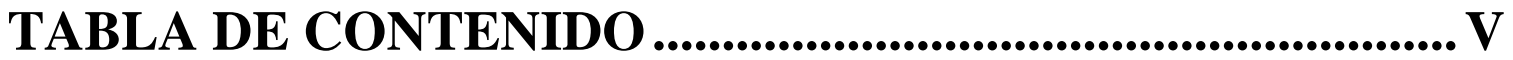

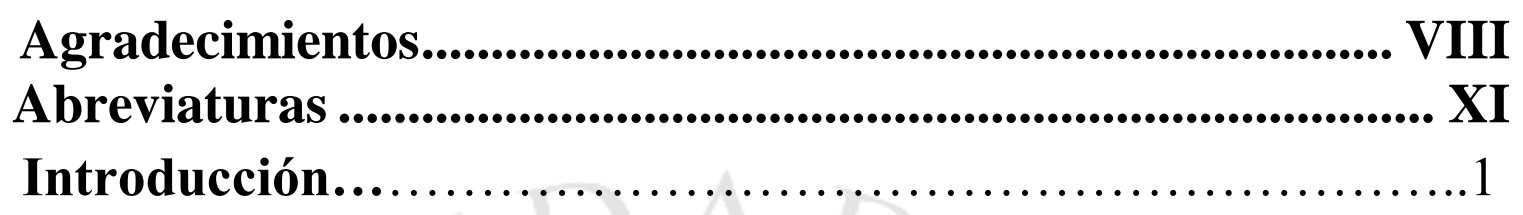

Capítulo 1: Aproximaciones históricas al objeto de estudio. ....7

1.1. Visiones Historiográficas ............................................................. 9

1.1.1. Historiografía Clásica ………………………………………………………. 9

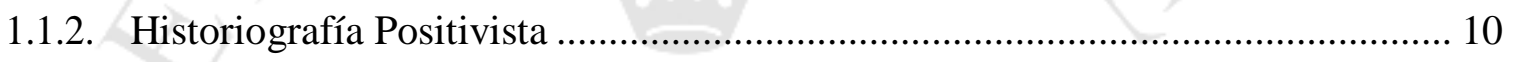

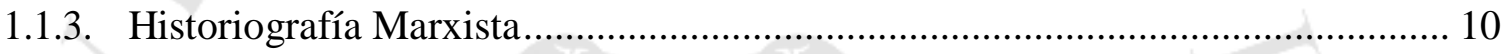

1.1.4. Historiografía de la Escuela de los Annales …………………………………….... 12

1.2. Aproximaciones histórico - jurídicas al objeto de estudio.................... 15

\section{Capítulo 2: Orígenes y Naturaleza del Derecho de Integración}

2.1. El Derecho de Integración como sub categoría del Derecho Internacional Público …………………………………………....... 16

2.1.1. Breve reseña y Características del Derecho Internacional Público ……………... 17

a) El Idealismo en las relaciones internacionales, influencia en el Derecho Internacional Público

2.2. El Derecho de Integración como rama independiente del Derecho ... 27

2.2.1. Características del Derecho de Integración ............................................................ 31

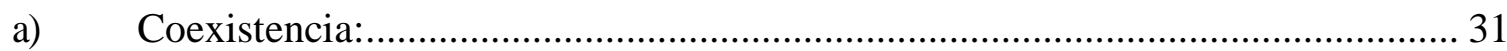

b) Cooperación:............................................................................................. 32

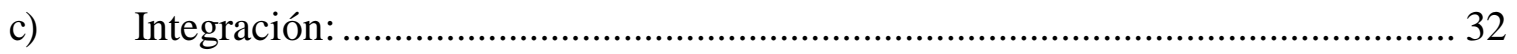

d) La Cesión de Soberanía ................................................................................ 33

2.2.2. El Realismo en las relaciones internacionales, influencia en el Derecho de

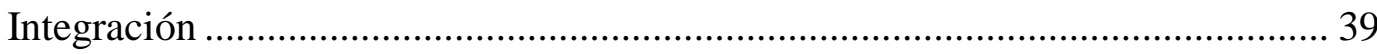




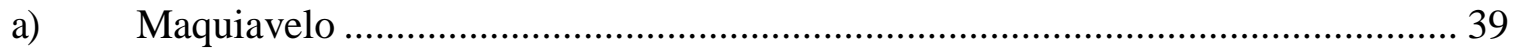

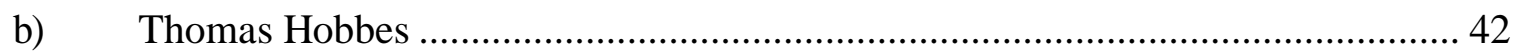

2.3. La Política Internacional como creadora del Derecho de Integración. 47

2.3.1. El Organismo Supranacional como “El Súper Leviatán”, el Tratado Fundacional como "Pacto Social Internacional".

a) Kelsen: Teoría General del Derecho y su visión del Estado................................... 51

b) Smend: La integración como proceso creador del Estado...................................... 53

2.3.2. La relación entre el Derecho de Integración y el Derecho Constitucional. ........... 64

\section{Capítulo 3: La Integración como proceso político y económico.}

3.1. Orígenes históricos de la Integración. ............................................. 74

3.2. Desarrollo del ser humano y pilares sociológicos de la integración .. 75

3.2.1. La supervivencia como primer pilar de integración ............................................. 76

3.2.2. La economía como segundo pilar de integración ................................................. 77

3.2.3. La religión como tercer pilar de integración......................................................... 78

3.2.4. La cultura como cuarto pilar de integración .......................................................... 80

3.3. Fases económicas del proceso de integración................................. 85

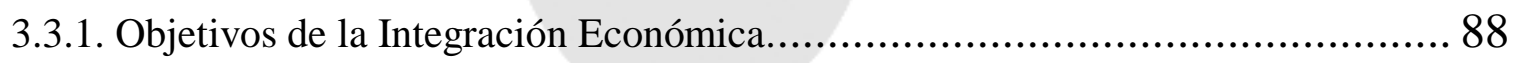

\section{Capítulo 4: La Unificación Alemana como caso emblemático} de integración ................................................................... 89

4.1. El surgimiento de Prusia como actor internacional (s. XVIII-XIX): De la Guerra de Sucesión Española, a Federico II El Grande................. 89

4.2. Las Guerras Napoleónicas y el Congreso de Viena: bases de la unificación alemana. ............................................................... 93

4.2.1. De la Confederación del Rhin a la Confederación Germánica: Teoría de la gravitación política de los Estados ...................................................................... 97

4.2.2. La Zollverein: inicios de la unificación alemana bajo el liderazgo de Prusia....... 98 
4.2.3. El parlamento de Frankfurt, primer intento fallido a la unificación.

105

4.2.4. Consolidación de la Zollverein y pérdida de influencia austriaca dentro de la Confederación Germánica.

4.3. Otto von Bismarck y el proceso de unificación alemana (1862-1871) 113

4.3.1. La Guerra de los Ducados, la derrota de Austria y la hegemonía prusiana en la Confederación (1866)

4.3.2. La Confederación Alemana del Norte.....

4.3.3. La Guerra Franco-Prusiana (1870-1871): La culminación del proceso de integración alemán y el surgimiento del II Reich

\section{Conclusiones}




\section{Agradecimientos}

"Nemo me impune lacessit."

"Nadie me ofende impunemente."

Lema del Reino de Escocia.

El presente trabajo de investigación, no hubiera podido concluir exitosamente sin el apoyo e influencia de las siguientes personas que menciono a continuación,

En primer lugar, agradecer a Dios todopoderoso porque sin Él nada somos, sus planes y designios siempre nos depara mejores resultados que los que originalmente nosotros mismos muchas veces planeamos.

A Galo Garcés Ávalos, incondicional y leal amigo, con quien comparto la pasión por la historia y la política internacional, gracias a él y muchas de nuestras tertulias, logramos armar la idea de este proyecto; esta tesis nunca habría nacido de no ser por ti querido Galo.

A Josef Zielinski Flores, asesor de la presente investigación, quien, en momentos de adversidad, sin conocerme, apostó por mí y este proyecto para poder sacarlo adelante, a él siempre mi eterna gratitud.

Agradecer a mi padre, Pedro Manuel Valega Núñez del Prado, quien siempre con su esfuerzo, consejo, guía y lealtad, acompañó de cerca mi proceso formativo, así como todo reto y desafío profesional en el que me he aventurado, por su amor e incondicional apoyo desde que tengo uso de razón, mi más sincero agradecimiento.

A mi abuela Carmen Gambetta Malatesta, por su cariño, dulzura y amor incondicional, por siempre estar atenta al desarrollo de esta investigación, por su paciencia en la demora de la misma y por haber sido una madre en todo momento para mí. 
A Juan Francisco Rojas Leo, quien siempre me dio todas las herramientas para poder desarrollarme profesionalmente, así como los libros principales para poder realizar la presente investigación, sin su apoyo, esta investigación no hubiera alcanzado el nivel esperado.

A Antonio Mires Gambetta y familia, por darme el espacio y tranquilidad para poder desarrollar mis proyectos de investigación y haber sido siempre para mí una segunda familia, a ellos mi cariño y agradecimiento.

A Raffaella Valega Ceccarelli, por su inocencia, ternura y haberme enseñado el amor más puro e infinito que jamás imaginé sentir, convirtiéndose en el motor de mi vida.

Agradecer a docentes que a lo largo de mi vida contribuyeron en mi formación, los cuales me dieron las herramientas intelectuales y materiales necesarias para desarrollar la presente investigación, entre quienes debo destacar a Amelia Bazán Velásquez, maestra responsable por desarrollar mi pasión por la historia, gran pasión intelectual, así como el pensamiento crítico y analítico, sin los cuales no se hubiera podido desarrollar esta investigación; A Luzmila Zapata, ex catedrática de la Universidad de Lima, quien me enseñó y dio las bases para aprender el Derecho de Integración; a Olga Ramírez Poggi, catedrática de la Universidad de Lima de los cursos de Política Internacional, Derecho de Integración y Derecho Internacional Público, quien siempre brindó su apoyo, asesoría, así como material de consulta para la presente investigación, a ella mi eterno agradecimiento por ser una amiga fiel e incondicional que me permitió descubrir mi vocación, la docencia.

Los amigos son la familia que escogemos para nuestra vida, por ese motivo no quiero dejar de agradecer a todos con los que conversé sobre esta investigación y otros proyectos que se trabajaron con anterioridad, gracias por sus consejos y opiniones. Especial mención a Gonzalo Morales López-Lavalle y familia, amigo que con el tiempo llegó a ser el hermano que nunca tuve, siempre leal e incondicional, más aún en los momentos de apremio, por todo y tanto, mi eterno agradecimiento a ellos.

Cabe agradecer también al personal de la Biblioteca de la Universidad de Lima y su siempre amable disposición y comprensión al momento de pedir los préstamos de libros y la renovación de los mismos, incluso cuando estos ya los plazos se encontraban vencidos. Mi 
mayor agradecimiento a todos.

Y finalmente a Carolina Loayza Tamayo, quien, con sus acciones, me dio la mejor lección para comprender que, con tiempo y paciencia, todos se ordenen en el lugar que les corresponde en la vida.

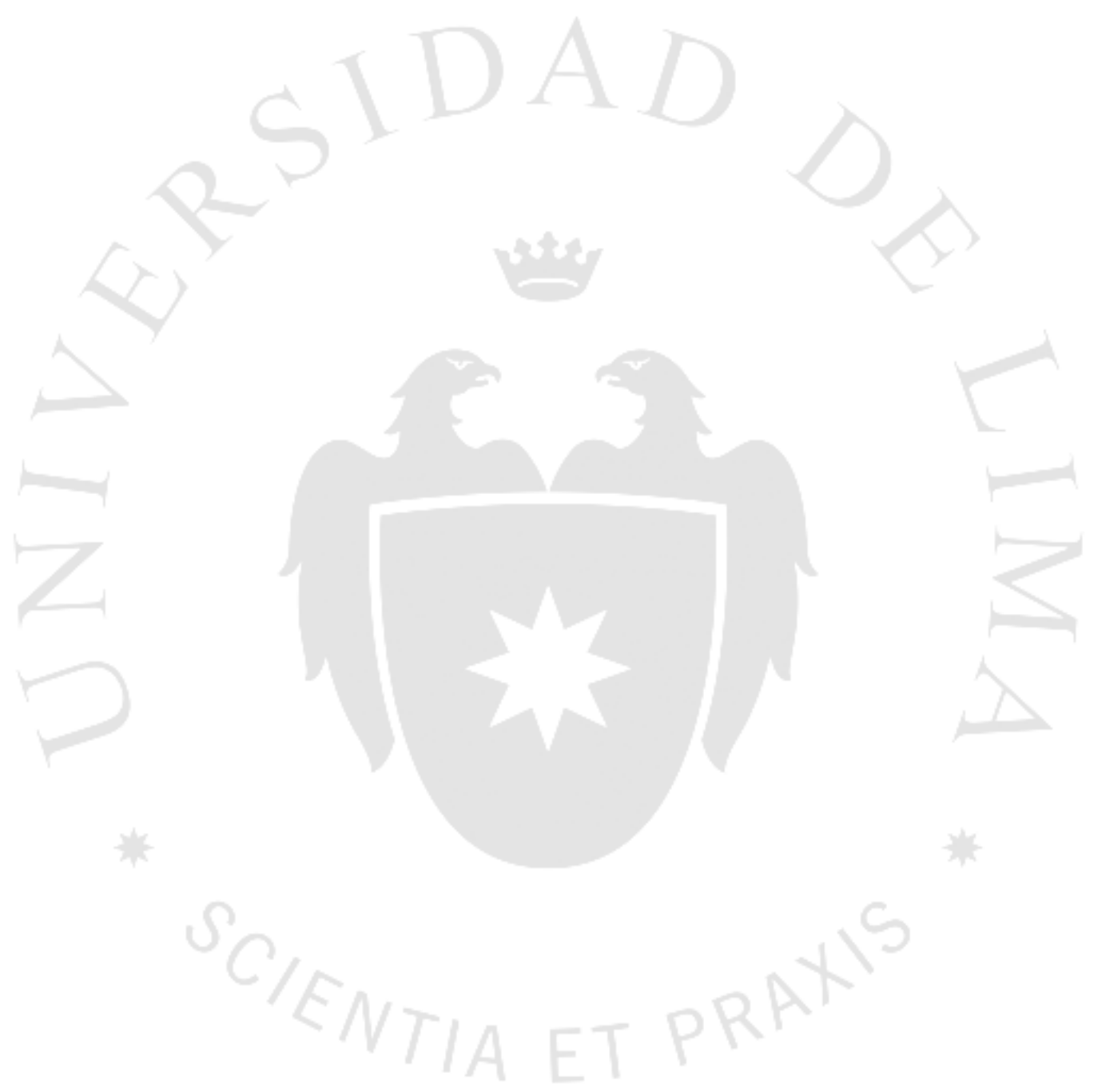




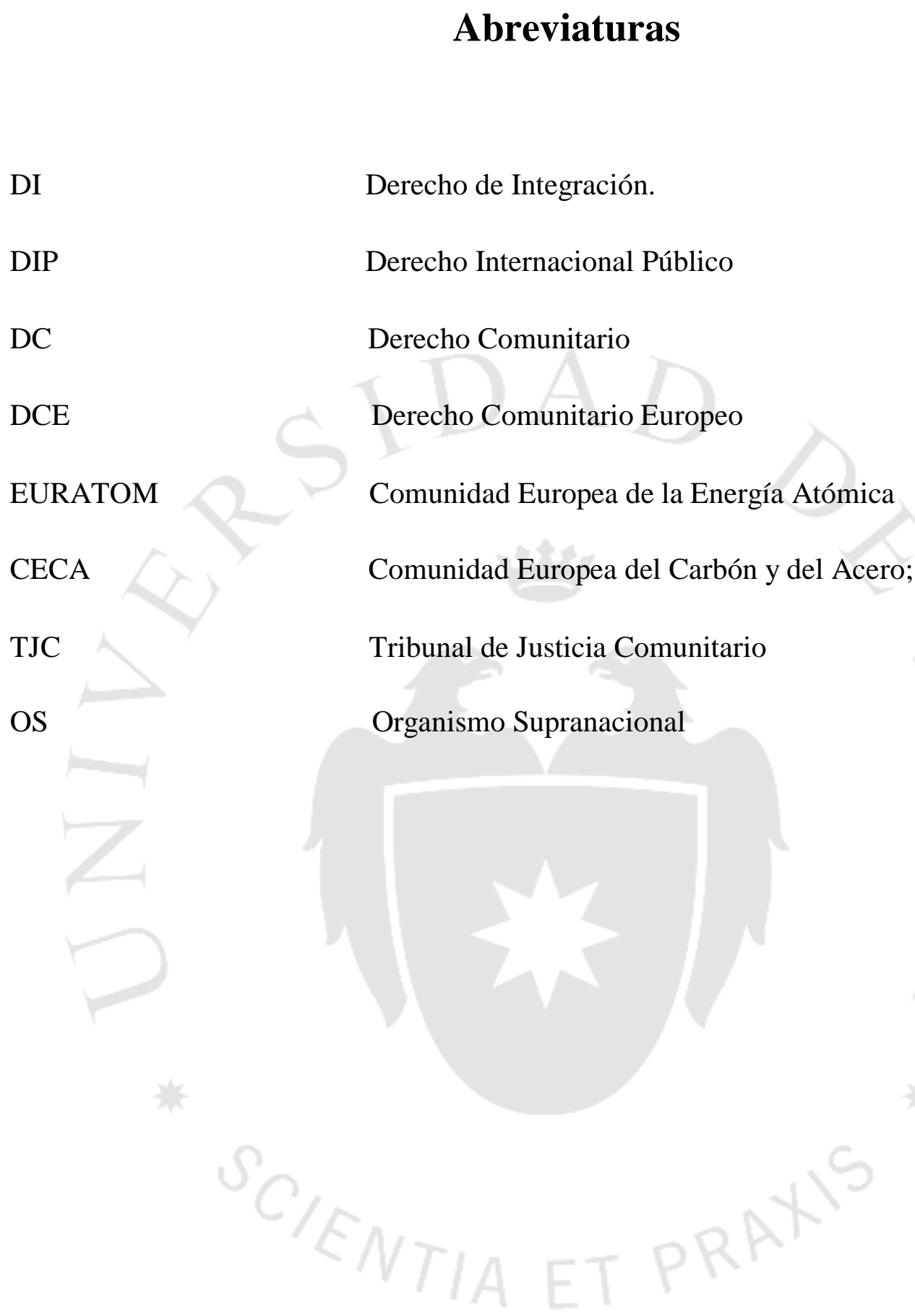




\section{Introducción.}

Las ciencias jurídicas encuentran su objeto de estudio en las normas, las cuales en su conjunto constituyen las diversas ramas del Derecho, tales como el Derecho Civil, Penal, Internacional, de Integración, entre otros.

Cuando se habla de la norma y el estudio de la misma, se puede abordar desde diversas perspectivas, tales como la sociológica -que explica el porqué de la conducta del individuo, la política -que explica las relaciones de poder entre el Estado y los individuos-, la económica -que realiza los diversos costo-beneficios de la norma así como sus implicancias para los sujetos sobre los cuales esta recae-; es decir la norma no solo debe ser estudiada bajo las ciencias jurídicas, sino con un enfoque multidisciplinario, dado que de esta manera es que se logra entender de manera completa el sentido mismo de esta, sus orígenes, implicancias y consecuencias.

Para la presente investigación, se optó por estudiar los orígenes de una rama relativamente “joven” del Derecho, el Derecho de Integración, el cuál por el proceso de globalización y de libre comercio y mercado de nuestra era, viene teniendo cada vez mayor relevancia e importancia.

Pero, ¿por qué centrar el objeto de estudio principal de la presente investigación en los orígenes de esta rama? Porque para entender el sentido, implicancias, características y relevancia, es primordial entender dónde, cuándo y cómo nace. No se puede saber hacia dónde se va, sin saber de dónde se parte.

A lo largo de la carrera universitaria, entre los cursos de Derecho Internacional Público, y Derecho de Integración, siempre hubo el debate sobre el origen de este último: era una subcategoría o una parte que componía al primero, -teoría sostenida por mucho de los catedráticos que imparten la cátedra de DIP-, mientras que los catedráticos especializados en DI, sostenían que este era una rama del Derecho en sí mismo y que por lo tanto no podía considerarse parte del DIP. No obstante, ambas teorías, con razones y argumentos muy validos cada una, no terminaban de dar una respuesta lo suficientemente clara y completa que satisfaga la necesidad de entender y sostener el origen del DI. 
No sería hasta terminar con el último curso electivo vinculado con Ciencia Política que ofrecía la Universidad de Lima, Política Internacional, que encontraría un indicio que llevaría tiempo después a dar con la respuesta y motivar la presente investigación: la política, más específicamente la Ciencia Política, entendiendo a esta ciencia como la encargada del estudio del poder en sus múltiples formas y alcances; dado que la política y el derecho van de la mano, son dos caras de una misma moneda, toda vez que las necesidades sociales propias de las relaciones del poder, encuentran en el derecho la herramienta para ordenar, conducir y buscar alcanzar los objetivos que toda sociedad anhela: seguridad y bienestar.

Años más tarde, tuve la oportunidad de cursar un diplomado en Geopolítica Estratégica que sería de vital importancia para dar forma y desarrollar la presente investigación. Puesto que dio las herramientas intelectuales para terminar de comprender ciertas características del poder que ya previamente se había aprendido los primeros años de estudios en la facultad, las proyecciones o alcances de la política (local e internacional) y como estos se relacionan entre sí.

Cuando hablamos del alcance local de la política, hablamos primigeniamente del Contrato Social, lo que con el desarrollo y evolución de las sociedades daría paso a lo que actualmente conocemos como el Derecho Constitucional, cuyo objeto nuclear es la constitución de la cual se desprenden las demás ramas menores del derecho encargadas de regular aspectos más específicos o técnicos de la vida humana, tales como el Derecho Civil, el Penal, Comercial, entre otros.

Sin embargo, la política también tiene un alcance externo, encargado de ver por las relaciones entre actores internacionales, es decir comunidades de individuos previamente organizadas, que se proyectan dentro de espacio geográfico con otras comunidades. Esta relación muchas veces caótica o agresiva, crea una necesidad, la de buscar relaciones lo más pacíficas y armoniosas posible. Esta necesidad llevaría a que sea a mediados de la Edad Media se cree una rama del Derecho: el Derecho Internacional Público, el cual padece de una gran debilidad, la falta de capacidad coercitiva para hacer cumplir de las obligaciones y lo acordado entre las partes. 
Por muchos siglos -incluso hasta la actualidad- se apostó por esta rama del Derecho como la herramienta capaz de velar y garantizar la paz mundial; no obstante, es por todos conocidos que este fin jamás ha sido alcanzado de manera efectiva y continua a lo largo de la historia de la humanidad, por justamente la falta de coercitividad, de poder obligar a los Estados de acatar o cumplir resoluciones. Con ello no se desmerece la gran utilidad del DIP como una herramienta eficaz y capaz de reordenar el escenario internacional después de periodos de convulsión internacional o guerra, pero sí la gran debilidad para que ese orden y paz se mantenga a lo largo del tiempo.

¿Qué lleva a que justamente el orden alcanzado por el DIP no se mantenga a lo largo del tiempo? Los intereses de los Estados son dinámicos, y estos influyen en la actuación de los primeros en el escenario internacional, motivados principalmente por garantizar dos elementos esenciales: Seguridad y Bienestar. Este dinamismo en los intereses de los Estados se debe, en gran medida a la influencia de factores externos, tales como nuevas tecnologías o descubrimientos que influyen en el escenario internacional y la interacción entre los mismos, creándose nuevas necesidades o intereses que alteran el equilibrio entre Estados y llevan a tensiones que muchas veces desembocan en conflictos que terminan por desordenar el escenario internacional.

Encontramos pues que la necesidad de paz y orden en el escenario internacional no tiene en el DIP la mejor herramienta o medio para satisfacer dicho anhelo de la comunidad internacional, ello en gran parte por un enfoque filosófico errado: el idealismo.

El plantear o proyectar cuestiones ético-morales a entelequias jurídicas carentes de moral o conciencia es el gran error del DIP, ya que parte de premisas incompletas o carentes de un entendimiento más profundo de la naturaleza del ser humano, puesto que considerar que, el hombre por su capacidad de razón puede someter sus instintos e impulsos y basar su conducta sobre la moral y la ética, en el fondo, más que una realidad, es una aspiración o un ideal. En segundo lugar, se observa que los idealistas, en la corriente de las relaciones internacionales, llevan este criterio a los Estados en donde si los Estados se relacionan con ética y moral se podrá alcanzar la paz, esto es otro error porque como ya se hamencionado, los Estados carecen de ética o moral como sí las personas naturales. Y en tercer y último lugar, que para que esa paz sea duradera, deberá existir una organización internacional 
nacida de la voluntad de los Estados de obedecerla -por razones "ético-morales"- para que vele y garantice la misma y no de una cesión de soberanía, cesión que sí encontramos en el Derecho de Integración.

No sería hasta con la Edad Contemporánea que se apostaría por un nuevo mecanismo jurídico para buscar lograr satisfacer las necesidades de la política internacional de buscar relaciones lo más pacíficas y armoniosas posible que garanticen la paz y el bienestar de los Estados, el Derecho de Integración.

Para hablar de D.I. es necesario hablar de las características que lo diferencia del DIP, en primer lugar, la soberanía. En este último el elemento nuclear, sobre el cual se constituyen los procesos de integración, radica en la sesión de soberanía que los Estados interesados por integrarse ceden y depositan en un Organismo Supranacional que será el encargado de regular las relaciones jurídicas en los ámbitos y competencias pactadas en el Tratado Fundacional.

Es decir, el D.I. tiene la característica de crear un nuevo ente con personería jurídica diferente a los Estados, con capacidad de actuación de forma eficaz, pero, sólo en los campos sobre los cuales, de forma libre, voluntaria y soberana, por convenir a sus intereses, deciden pactar los Estados interesados en integrarse.

Esto lleva una segunda característica, la libertad, el deseo autónomo por ceder, por desprenderse de parcelas de soberanía, porque persiguen un fin ulterior, un fin en el que encuentran un mejor medio o camino para alcanzar los objetivos que cada Estado persigue en el escenario internacional.

Otra característica que se aprecia con el D.I. es el paralelismo que existe con el Derecho Constitucional, o específicamente, el símil que existe entre el Tratado Fundacional, con el Pacto Social, dado que es a través de este último que se termina por dar forma y crear al Estado, con el Tratado Fundacional se constituye un nuevo ser, el Organismo Supranacional, responsable de regular en las materias pactadas y las relaciones entre los Estados parte, siendo este último el responsable de velar por el entendimiento, con capacidad de acción y de imponerse, ya que a diferencia del DIP, no parte de un "deber ser", sino de un elemento concreto, soberanía. 
Otro elemento de vital importancia que merece ser mencionado en relación al D.I. y los procesos integradores que se configuran entorno a esta rama del Derecho, es la estrecha relación que hay con el comercio. Muchos procesos integradores nace principalmente de acuerdos de libre comercio, que con el devenir de los años van evolucionando en zonas aduaneras, mercados comunes, entre otros, dando paso que, si bien en un primer momento la integración es comercial o económica, esto sea el primer paso o cimiento sobre el cual se sostengan procesos de integración política o en otro tipo de materias.

Cuando hablamos de D.I., lo primero que viene a la mente es el Derecho Comunitario de la Unión Europea, y es justamente esta última, con quien se asocia a la presente rama del Derecho. Sin embargo, esta, si bien es el caso emblemático o más conocido, no sería el primer caso de éxito a lo largo de la historia, encontrando al proceso de integración germánico, comprendido en el periodo de la Confederación Germánica al II Reich, como el primer caso emblemático de éxito de un proceso integrador constituido por elD.I.

Como se observa, encontramos dos casos de éxito, casos en donde las necesidades propias de la política internacional, seguridad y bienestar, han sido atendidas y mantenidas satisfactoriamente, pero habría que hacer la siguiente interrogante ¿A qué se debe el éxito alcanzado?

Parte de este éxito responde a un enfoque filosófico realista; es decir, el reconocer la naturaleza conflictiva de los individuos, las cuales se termina proyectando en los Estados que componen, frente a esa naturaleza, reconocer que tanto individuos como Estados, actúan en sus respectivos espacios físicos motivados por el deseo de sobrevivir y de alcanzar el bienestar, y que justamente esos deseos o motivaciones, obliga a que en aras de lograrlo, se apuesta por la integración como medio efectivo que lo garantice y conduzca, puesto que en última instancia resulta más beneficio estar integrado con semejantes que en solitario, por ella la frase "Los Estados no tienen amigos, tienen intereses comunes", sintetiza claramente lo que esta corriente plantea para lo que relaciones internacionales respecta.

Por ello, y habiendo dado un breve resumen de lo que la presente investigación aborda, la finalidad de este trabajo es confirmar que el caso práctico, en donde la teoría jurídica del D.I. se plasma en la realidad, se da con el proceso de unificación alemán del siglo XIX. 
Seguidamente, lo que se buscará demostrar es que, si bien el Derecho de Integración es una rama independiente del Derecho, esta al igual que el Derecho Internacional Público, tienen un origen común en la política, específicamente en la política internacional.

Para ello, se demostrará la estrecha relación de la corriente realista de la política internacional en el D.I. dado que los procesos de integración en un primer momento se dieron dentro de individuos y comunidades que se integraron entre sí para garantizar la supervivencia de los mismos, en ese mismo sentido, los Estados, al ser proyecciones de los individuos y comunidades que los componen, apuestan por este mismo proceso llevado a cabo por el DI, motivados por intereses geopolíticos dentro del escenario internacional, siendo el tratado fundacional una especie de "Pacto Social Internacional" que garantiza la convivencia pacífica entre los estados, es decir, es DI es finalmente la herramienta jurídica que ayuda a mantener y garantizar la paz en los espacios geográficos donde este se aplica.

Para que finalmente determinar que el éxito de un proceso de integración se sostiene en cuatro pilares: Supervivencia, Economía-bienestar, Religión y Cultura; puesto que el éxito de dicho proceso se sostiene en la convergencia de similitudes en los pilares antes mencionados: que los Estados por integrarse compartan un deseo por garantizar su supervivencia y/o seguridad en el escenario internacional, que busquen el bienestar y crecimiento económico de manera conjunta y que finalmente compartan valores y cosmovisiones afines entre sí. 


\section{Capítulo 1: Aproximaciones históricas al objeto de estudio.}

Como bien ya se detalló en la introducción, este trabajo responde a una inquietud históricojurídica, ¿el DI nace con el proceso de Integración Europeo, que tiene como punto de partida a la Comunidad Europea del Carbón y del Acero (CECA) en el año 1951 y como consolidación a la Unión Europea de inicios de los años 90’?

Como se estableció en la introducción, el DI es el resultado de una serie de procesos políticos visto a lo largo de la historia de la humanidad, que tuvieron como objetivo integrar a una serie de organizaciones político-administrativas sobre una serie de elementos diversos, con la finalidad de garantizar la supervivencia de éstos en el escenario internacional, dichos procesos político dieron como resultado que con el proceso de integración germánico materializado en la Confederación Germánica (1815 a 1866) y con el nacimiento del II Reich, como culminación y consolidación de dicho proceso integracionista, naciera esta rama del Derecho.

Para poder responder esta interrogante, hay que primero dejar sentado que, si bien la inquietud es primordialmente jurídica, también tiene componentes multidisciplinarios como son, la Historia, la Historia del Derecho, la Geopolítica y las Ciencias Jurídicas, las cuales en su conjunto constituyen a lo que se denomina "Ciencias Sociales"1

Para ello, se comenzará con abordar cada uno de estos puntos para, dejar establecido qué son y cómo nos van a servir dichas ciencias y disciplinas sociales en el desarrollo de la presente investigación.

La historia es "la disciplina que estudia y expone, de acuerdo con determinados principios y métodos, los acontecimientos y hechos que pertenecen al tiempo pasado y que constituyen el desarrollo de la humanidad desde sus orígenes hasta el momento presente." (University of Oxford, 2016). Es también la disciplina que estudia y narra cronológicamente los acontecimientos pasados (Real Academia Española, 2016).

\footnotetext{
${ }^{1}$ Se denomina Ciencias Sociales a todos aquellos campos del saber que estudian y analizan distintos aspectos de la humanidad, sea los individuos o los conjuntos de éstos, enfocándose en sus manifestaciones materiales (arqueología, antropología forense, entre otras) como inmateriales (ciencia política, sicología, entre otras).
} 
Teniendo como definiciones centrales las antes mencionadas, se puede establecer que será historia, todo aquel tema se pueda ser registrado para un estudio posterior. Es pues una gran disciplina con una metodología específica, que se compone por ramas más pequeñas (historia del arte, historia de las ideas políticas, historia del pueblo alemán ${ }^{2}$, entre otros).

Dentro de toda esa pluralidad de ramas históricas, hay dos que serán tomadas como ejes centrales para el desarrollo de la presente investigación: La Historia del Derecho y el Geschichte des deutschen Volkes o historia del pueblo alemán.

Para poder dar paso a la definición de la Historia del Derecho, es imperante primero definir qué se entiende por Derecho, ya que se puede hablar de la historia de éste, sin saber qué es.

Sobre el Derecho existen una gran variedad de definiciones, dependiendo de la corriente filosófica por donde éste sea estudiado, se considera que al definir al Derecho ${ }^{3}$ como "un sistema racional de normas sociales de conducta, declaradas obligatorias por la autoridad, por considerarlas soluciones justas a los problemas surgidos de la realidad histórica" (Toranzo, 1987, p. 127) condensa las visiones de los diversos enfoques jurídico-filosóficos que define al Derecho (positivista, naturalista, entre otras), en un concepto mucho más completo y por consiguiente, exacto.

Teniendo claro el concepto del Derecho sobre el cual se va a desarrollar la presente investigación, se dará paso a definir a la "Historia del Derecho".

La Historia del Derecho es el resultado de combinar dos de los conocimientos más "humanísticos" o exclusivos ${ }^{4}$ de la condición humana, la Historia -ciencia cuyo objeto de

\footnotetext{
2 Es oportuno precisar que tradicionalmente en Alemania la historia no es abordada como "Historia de Alemania", sino como "Historia del Pueblo Alemán" (Geschichte des deutschen Volkes) toda vez que el pueblo alemán, o germánico siempre habitó más territorios que los que actualmente se conocen como Alemania. Así mismo también existieron una diversidad de Estados, distintos entre sí, pero cuya composición nacional estuvo conformada por el pueblo germánico.

${ }^{3}$ Existen diversas escuelas del Derecho que dan una serie de definiciones diferentes una de otras, dependiendo de la escuela filosófica de la cual pertenezca el autor. En el presente caso, se tomó la presente definición por considerarla afín con la visión que se tiene del derecho y para el objetivo de la presente investigación.

${ }^{4}$ Decimos que son exclusivas, porque los seres humanos somos los únicos seres vivos capaces de hacer historia y registrarla; asimismo, de establecer un sistema normativo, Derecho, (escrito, oral o consuetudinario) capaz de permitirnos una organización social compleja y elaborada, materializada en la gran variedad de imperios y civilizaciones a lo largo de la historia de la humanidad.
} 
estudio radica en el estudio del pasado- y el Derecho - arte intelectual y ciencia dialéctica en cuya aplicación se determina el derecho de cada uno en sociedad (Zegarra Mulánovich, 2009, pp. 29-33).

Asimismo, la Historia del Derecho, según la obra de Eloy Suarez, es la rama de la Historia que se encarga del estudio del nacimiento y evolución del Derecho hasta nuestros días, sin que los factores de espacio (territorialidad) y tiempo, afecte en su estudio. ${ }^{5}$ (Suárez, 2004)

\subsection{Visiones Historiográficas}

La historia, como ciencia social, ha tenido un proceso de evolución y desarrollo a lo largo del tiempo, teniendo una serie de escuelas, las cuales dan un enfoque característico al momento de "hacer historia", de registrar los hechos. Por eso motivo, es que se considera fundamental hacer hincapié al mencionar y explicar brevemente cada una de ellas, para luego definir cuál es la escuela historiográfica sobre la cual se construye nuestra investigación.

\subsubsection{Historiografía Clásica}

Es la escuela historiográfica que nace con la escritura y tiene como su mayor y mejor referente la cultura helénica. Esta escuela tiene como característica central la enumeración o narración de los hechos pasado, en los cuales los historiadores de esta escuela, ven la historia como ejemplo moral (caso de Plutarco y sus Vidas Paralelas) o como análisis político (caso de Tucídides y su Historia de la Guerra del Peloponeso) (Garcés Ávalos, 2016, p. 27).

\footnotetext{
${ }^{5}$ Esta sería una definición amplia de la Historia del Derecho; sin embargo, sí pueden existir factores de temporalidad y espacio que afecten esta rama del derecho, por ejemplo "Historia del Derecho Peruano en el siglo XX"
} 


\subsubsection{Historiografía Positivista}

Acorde con lo señalado por la Universidad Nacional Autónoma de México:

El concepto positivismo surgió de los trabajos de Augusto Comte, quien dividió la historia de la humanidad en tres estadios diferentes y el tercero era el positivo, caracterizado por lo certero, real y preciso, de ahí que esta corriente de pensamiento historiográfico esté en la búsqueda permanente del dato cierto, real, útil y preciso.

El positivismo postula la idea de progreso como definición del devenir histórico. Concibe a la historia por etapas que van de la barbarie hacia el desarrollo; donde cada una es mejor que la anterior; y concibe el tiempo unilinealmente y no reconoce retrocesos (Universidad Nacional Autónoma de México, 2016).

Asimismo, sostiene que:

Postuló que el investigador debía estar alejado temporal y anímicamente del objeto de estudio para estudiarlo objetivamente; explica que el historiador no puede ni debe interpretar sino solamente acumular datos para describir objetivamente el suceso. Su intención era encontrar el dato puro y construir leyes históricas.

El positivismo es el responsable de dotar a la historiografía de su primer método para darle carácter científico. Sus principales representantes son Leopold von Ranke, Jules Michelet, Denis Fustel de Coulanges. Su origen se ubica en los inicios del siglo XIX en Francia, aunque fue en la actual Alemania, donde tuvo muy importantes representantes (Universidad Nacional Autónoma de México, 2016).

\subsubsection{Historiografía Marxista}

Dicha escuela, como su propio nombre lo evidencia, está estrictamente ligada a Karl Marx, el comunismo y al proceso de análisis crítico denominado "Concepción materialista de la historia”. Para entender a la escuela Marxista y la concepción que esta tiene sobre la historia, se tiene que recurrir a su vez a las tres ramas que se desprenden de esta según (Moradiellos, 1994; Ramírez Bacca, 2010): 
a) El Marxismo Ortodoxo: Es dentro del marxismo historiográfico la rama más dogmática, construyendo la historia sobre la base de las interpretaciones economicistas lineales. Como uno de sus puntos de mayor debilidad, es que sus argumentos interpretativos son basados más en los principios ideológicos del marxismo, que en la investigación histórica misma.

b) El Marxismo Estructuralista: Tiene como mayor exponente a Luis Althuser, el cual considera que la sociedad estaba formada por una jerarquía de estructuras, diferentes unas de otras, que gozaban de una relativa autonomía, aunque condicionada por consideraciones económicas en última instancia. Así pues, la historia era un proceso sin sujeto. Los seres humanos pasaban a ser meros soportes o efectos de las estructuras de la sociedad. A su vez, esta perspectiva implicaba una lectura antihumanista de Marx en la que se rechazaba la idea de una naturaleza humana universal, que gozaban de una cierta autonomía, aunque en última instancia, condicionada por factores económicos.

c) El Marxismo Empírico: Tiene como máximos representantes a Hobsbawn, Anderson y Thompson, los cuales toman al marxismo no como un sistema teórico sino como una orientación que ofrece "señales" sobre problemáticas relevantes para el análisis empírico.

Como síntesis a esta escuela historiográfica, si bien existen matices o diferencias entre cada una de ellas, todas finalmente parten de una visión de la historia desde la perspectiva e interpretación de las clases sociales (principalmente las históricamente "oprimidas") y con un enfoque en donde el desarrollo histórico, acorde con esta escuela, se da con la lucha de clases dirigida a la lucha de clases en el desarrollo histórico.

Esto finalmente va a terminar siendo una tara para la escuela historiográfica marxista puesto que es una corriente profundamente influenciada por un sesgo ideológico, lo cual le resta objetividad e imparcialidad al producto final elaborado por el historiador de esta escuela. 


\subsubsection{Historiografía de la Escuela de los Annales}

La Escuela de los Annales, es la escuela historiográfica que ve a la historia no como un compendio de hechos (como lo veían la escuela clásica o la positivista), sino como un proceso, es decir ver a esos hechos, no como islas u objetos aislados o específicos, sino entender y ver a la historia como un compendio de hechos concatenados y relacionados entre sí.

Los principales exponentes de esta escuela fueron Lucien Febvre (1878-1956) y Marc Bloch (1886-1944), quienes, a fines de la década del 20 del siglo pasado, esbozaron esta escuela teniendo una visión vanguardista y revolucionaria para sus tiempos, puesto que rompieron con una estructura imperante que por mucho tiempo rigió la forma en la que se hacían los trabajos historiográficos (la escuela clásica y la escuela positivista).

Ellos comenzaron en un primer momento a desconfiar de la historia tradicional y las limitaciones que sus fuentes primarias, las crónicas, (principalmente el apego rígido que los historiadores tradicionales tenían a las descripciones de los hechos de las crónicas que se apreciaba en las escuelas antes mencionadas) podían aportar. De esta manera, renovaron la forma de hacer historia, ampliando los elementos que tendrían presentes los historiadores al momento de ver la historia y analizar el contexto en el cual se desarrollaban los distintos procesos históricos de la humanidad.

La renovación que supuso la Escuela de los Annales a la historiografía se plasmó en la enorme ampliación de los campos de trabajo y en el uso de métodos de investigación tomados de otras disciplinas; buscó además una visión en torno a una historia total, un enfoque que permitiera estudiar todas las actividades humanas y su relación mutua. Los historiadores de Annales se volcaron a estudiar, con métodos innovadores, procesos de "larga y mediana duración" sobre marcos geográficos específicos y asuntos poco tradicionales y metapolíticos (Garcés Ávalos, 2016, p. 30).

Asimismo, y en concordancia con (Ramírez Bacca, 2010, p. 187):

Ellos [los historiadores de los Annales] consideran que la nueva historia debía hacerse a partir de las limitaciones documentales. Los historiadores debían lograr 
también una comprensión en torno al idioma, el arte, el paisaje topográfico, la estructura material, la fauna y la flora. Era necesario construir diálogos con nuevas disciplinas como la geografía, la economía, la sociología y la antropología, además de plantear un nuevo tipo de preguntas a los documentos. Afirman que los historiadores deben lograr sus objetivos y nuevos enfoques a través de la búsqueda de datos. El pasado no existe, son los historiadores los que lo crean. Esta declaración se orientaría hacia una historia objetada. La ambición era lograr, como ya se mencionó, escribir una historia total, en la cual se integrarán nuevas áreas y aspectos de la sociedad.

Finalmente, la Escuela de los Annales se sintetiza en una sola palabra "Comprender" (Bloch, 1995, p. 112). Porque para comprender, es necesario no solo analizar y ver el hecho en sí, es tener la perspectiva y el panorama es, en buena parte, no solo ver el árbol, sino ver el bosque y el ecosistema que lo rodea, para poder, de esa forma, ubicarnos en la relevancia e importancia del proceso histórico que se estudia.

Por lo antes señalado, es que la Escuela de los Annales va a ser la escuela historiográfica sobre la cual se realizará todo el análisis histórico de la presente investigación, porque como ya se señaló al comienzo del presente capítulo, el DI no es un hecho aislado que nace por sí mismo y de la noche a la mañana, es un proceso iniciado por factores ajenos a las Ciencias Jurídicas.

Como punto de partida para este proceso, se considera la necesidad vital de los Estados de poder asegurar su supervivencia en el escenario internacional, sea manteniendo cierta independencia dentro de una comunidad de Estados (es decir crear un Organismo Supranacional), o bien constituyendo un nuevo Estado junto con otros. Es por eso que en el DI, esta necesidad, la cual es principalmente geopolítica, encuentra el mecanismo y el medio para poder plasmar y de tener éxito, consolidar el proyecto de integración de los Estados.

Ahora, para entender esa necesidad de los Estados y principalmente en el caso de estudio, es necesario analizar el contexto en el que se generaron las condiciones que llevó a la necesidad de los diversos Estados Germánicos de integrarse unos con otros, y que mejor escuela historiográfica, que la Escuela de los Annales. La cual enfatiza la relevancia e importancia del análisis de los contextos que rodean a los hechos históricos, así como el 
apoyo multidisciplinario para poder lograr un mejor entendimiento y, por ende, una mejor aproximación a la verdad histórica del hecho investigado.

Con lo antes señalado, se quiere reivindicar lo que a criterio propio es la mejor forma para poder comprender los procesos jurídicos ${ }^{6}$, y es pues la aplicación, no solo de las Ciencias Jurídicas mismas para estos procesos, sino la aplicación conjunta de esta última con la Ciencia Política, ya que no se puede terminar de comprender la real dimensión de un proceso jurídico o político sin un análisis conjunto de estas dos ciencias sociales. ¿Por qué se afirma esto? Puesto que ambos tienen como elemento nuclear común, el poder.

La Ciencia Política aporta el estudio y teorización del poder en sus múltiples formas (relaciones de poder, relaciones entre actores políticos, organizaciones y estructuras de poder, entre otras más), y las Ciencias Jurídicas, aporta el estudio y la teorización de cómo este poder será ejercido entre sus múltiples campos y actores. En un sentido más práctico, las Ciencias Jurídicas, a través del Derecho, regulan el ejercicio del poder entre sus múltiplos actores y diversos niveles a través de la conceptualización de normas que otorgan derechos y obligaciones para los sujetos sobre los cuales se aplicará.

Por eso es que no puede existir Derecho sin poder, ya que no existiría el medio coercitivo/disuasivo por el cual el primero se impone para regular los diversos campos donde este se aplica; pero tampoco se puede hablar de poder sin que exista Derecho, ya que este último termina poniendo los límites necesarios $-\mathrm{y}$ considerados justos por la sociedad- al ejercicio del primero, para que este no sedegenere en un ejercicio abusivo, garantizando de esta forma el bien común y el desarrollo del Estado de Derecho.

Acorde con (Sabine, 1994, p. 275) en su análisis del pensamiento de Maquiavelo, explica notablemente, para efectos de este autor clásico del pensamiento político occidental, la importancia del Derecho para regular la vida en sociedad, así como el poder político: Porque si lo individuos humanos son por naturaleza radicalmente egoístas, el estado y la fuerza que hay tras el derecho tienen que ser el único poder que mantenga unida a la sociedad (...).

\footnotetext{
${ }^{6}$ Por procesos jurídicos nos referimos al desarrollo del Derecho y todas sus diversas ramas que lo componen.

7 Antiguamente en las universidades peruanas se enseñaba la carrea de Derecho como “"Derecho y Ciencia Política", lastimosamente hoy en día se separó este binomio en aras de alcanzar una mejor "especialización" en cada uno; sin embargo, dicha separación termina por debilitar una comprensión profunda y amplia de ambos.
} 


\subsection{Aproximaciones histórico - jurídicas al objeto de estudio.}

Habiendo definido la metodología histórica que se va a emplear para la presente investigación, se dará paso a desarrollar la "Historia Externa" e "Historia Interna" del Derecho de la Integración.

Acorde con lo señalado por Garcés Ávalos en su tesis "De Augsburgo a Westfalia: El nacimiento del Derecho Internacional Moderno":

La "Historia Externa" hace alusión a la historia de las fuentes formales del derecho y las circunstancias socio-políticas que las determinaron, es decir, una historia de la legislación. Por su parte, la "Historia Interna" trata de la vida y transformación de las instituciones jurídicas, y requiere del estudio de la historia de los institutos e instituciones particulares - ergo, de la "Historia Externa" (Garcés Ávalos, 2016)

Asimismo, según lo señalado por (Reale, 1988, p. 239) los estudios históricos del derecho pueden abordar los siguientes enfoques:

La Historia del Derecho se puede desarrollar en tres planos mutuamente relacionados: el de los hechos que explican la aparición de las soluciones normativas y las mutaciones acaecidas en el ordenamiento jurídico dando particular relieve a las fuentes del derecho; el problema de las formas técnicas con que se revisan tales soluciones normativas mediante la constitución de modelos institucionales; el de las ideas jurídicas que actúan como fines en las modificaciones realizadas en las fuentes y en sus modelos normativos.

En la presente investigación, es importante plantear una alternativa sobre la "Historia Externa” del DI, y para ello es fundamental que nuestro análisis histórico deba ser efectuado a través de la Escuela de los Annales, es decir, el nacimiento y desarrollo del DI, entendido como un proceso histórico que se fue desarrollando a lo largo de la historia de la humanidad, ya que entenderlo de otra manera - solamente como un hito o hecho relevante dentro de la Historia del Derecho-, nos encasillaría en un análisis histórico positivista, el cual impediría una mayor profundidad en el entendimiento de este proceso del cual surgió el DI. 


\section{Capítulo 2: Orígenes y Naturaleza del Derecho de Integración}

En la actualidad, existe un gran debate dentro del mundo académico en relación al origen y condición del DI. Para un sector, este último nace dentro del seno del DIP puesto que el elemento constitutivo del DI es el tratado, "Al ser el tratado el típico instrumento normativo del Derecho Internacional público, necesariamente se habría de incardinar el Derecho Europeo $^{8}$ dentro del marco de este último” (Robles Morchón, 1996, p. 29); por este origen común, es que termina siendo una rama del DIP.

\subsection{El Derecho de Integración como sub categoría del Derecho Internacional Público}

Acorde con Timothy Moorhead, la comprensión del Derecho Comunitario Europeo (Derecho Integración) ${ }^{9}$ como parte del Derecho Internacional Público, constituye un modo de explicar la cualidad rectora de los tratados sobre las prácticas institucionales de las organizaciones supranacionales, tomando como referencia el caso de la Unión Europea (Moorhead, 2012, pp. 143-144).

Acosta Estévez utiliza las características del Derecho Comunitario Europeo para explicar por qué el Derecho de la Integración podría ser susceptible al Derecho Internacional Público. Este sostiene que es un "particularismo jurídico" contrapuesto al "universalismo" que sería el DIP debido a que,

“(...)se caracteriza por los siguientes rasgos: 1) atendiendo al ámbito geográfico $(\ldots), 2)$ sobre la base de una producción normativa (...) en el seno de una organización internacional (...), 3) la creación de normas particulares del DCE ${ }^{10}$ tienen su razón de ser en los Tratados constitutivos de las Comunidades Europeas

\footnotetext{
${ }^{8}$ Acorde con Robles Morchón, (1996, p. 27) junto al Derecho de la Comunidad o Derecho Europeo Comunitario los autores, especialmente alemanes utilizan la fórmula de "Derecho de Europa" (Europarecht) para referirse a las normas que regulan al DI.

${ }^{9}$ Entiéndase al Derecho Comunitario Europeo como una especie del Derecho de Integración, es decir una relación de Género (DI) y especie (Derecho Comunitario Europeo (Sobrino Heredia, Algunas Consideraciones en Torno a las Nociones de Integración y de Supranacionalidad, 2001)

${ }^{10}$ Derecho Comunitario Europeo.
} 
y en los procedimientos de elaboración normativa de los mismos; y 4) (...) desde el plano de la sectorización operada en la esfera del DIP, el DCE es una rama específica del DIP.” (Acosta Estévez, 2004, p. 2).

Continua en esa misma línea, considerando al Derecho Comunitario Europeo como un "subordenamiento jurídico del ordenamiento jurídico internacional, (...) una subespecie internacional sui generis”, cuyo fundamento en el Derecho Internacional Público se basa en el tratado fundacional de la organización internacional, como es el caso de la Unión Europea (Acosta Estévez, 2004, p. 7).

Asimismo, acorde con Yésica Biquez, los Estados se relacionan mediante acuerdos o tratados en función del Derecho Internacional Público, los cuales, establecen las diferentes formas en las que se va a desarrollar la integración. Por lo tanto, llega a la conclusión que el "Derecho de la integración es una rama especializada del Derecho internacional público que regula un proceso de integración de cualquier tipo. El derecho de la integración no es autónomo, sino una parte especial del Derecho Internacional” (Biquez, Pereyra, Estevez, Curbelo, Brunetto, \& Bas, p. 11).

\subsubsection{Breve reseña y Características del Derecho Internacional Público}

Acorde con (Garcés Ávalos, 2016) el DIP, como se entiende en nuestros días, fue el resultado de un proceso que tuvo como punto de partida la Paz Religiosa de Augsburgo ${ }^{11}$ (1555) en donde se establecieron parte de los principios del DIP, tales como "Principio de Soberanía", "Principio de No Intervención" y "Principio de Prohibición del uso de la fuerza" ${ }^{\prime 2}$. Seguidamente, se encuentra que en la Paz de Westfalia ${ }^{13}$ (1648) los principios surgidos en Augsburgo antes mencionados, llegan a internacionalizarse, es decir a difundirse en un mayor ámbito de alcance -dado que trasciende las fronteras del Sacro Imperio Romano-Germánico-; asimismo, se logra el afianzamiento del Nuevo Orden y Derecho

\footnotetext{
${ }^{11}$ La paz de Augsburgo fue un tratado firmado por Fernando I de Augsburgo, hermano y representante de Carlos $\checkmark$ y las fuerzas de la Liga de Esmalcalda, por la cual se resolvió el conflicto religioso de la reforma protestante.

12 Artículos 14으, 15으 y 23으 respectivamente de la Paz Religiosa.

${ }^{13}$ Se refiere a dos tratados de paz de Osnabruck y Munster, por los cuales se finalizó la guerra de los Treinta Años y la Guerra de los Ochenta Años entre los Países Bajos y España.
} 
Internacional, así como del Sistema de Estados que rige hasta nuestros días.

Por estos hechos es que al igual que lo mencionado por Garcés Ávalos, con Augsburgo se sientan los principios del DIP, pero con Westfalia estos se difunden y expanden, con las características y aportes antes mencionados.

Sin embargo, habría que formularnos la siguiente pregunta, ¿qué es el DIP?

Según la definición de (Lauterpacht, 1970), el DIP es el Derecho de la Comunidad Internacional $^{14}$

Según (Garcés Ávalos, 2016, p. 33),

(...) el Derecho Internacional es el cuerpo de normas de conducta, ejecutables por sanción externa, que confiere derechos e impone obligaciones, aunque no de forma exclusiva, sobre Estados soberanos ${ }^{15}$ y que deben su validez tanto al consentimiento de los Estados expresado en la costumbre y tratados, y también a la existencia de una comunidad internacional conformada por Estados e individuos.

Acorde con (Oppenheim, 1961) el Derecho Internacional Público es el conjunto de reglas consuetudinarias - la costumbre- aplicada en las relaciones entre los Estados, las cuales muchas veces pueden "positivizarse" a través de tratados, otorgándole a esta "costumbre" una mayor fuerza jurídica obligatoria entre los suscriptores.

Por su parte, (Diez de Velasco, 1963) y en una línea similar a la de Lauterpacht, concibe al DIP como el conjunto de normas agrupadas en un sistema que constituye el ordenamiento jurídico de la Comunidad Internacional.

Para (Álvarez Londoño, 2007) el Derecho Internacional Público es “(...) un conjunto de reglas que se aplican a los sujetos de la sociedad internacional, es decir normalmente los

\footnotetext{
14 Entiéndase por Comunidad Internacional, al conjunto de Actores Internacionales -Estados, Organismos Internacionales, entre otros.

15 Garcés Ávalos realiza la siguiente nota: "Definimos al Estado Soberano como aquella comunidad que se gobierna plenamente a sí misma y de forma independiente, en términos generales. Para Vattel, "el gobierno propio es el aspecto interno y la independencia el aspecto externo, de la soberanía estatal", mientras que para Hegel "El Estado es el ordenamiento supremo y no reconoce superior". Shaw (1991) enfatiza el hecho que los principales individuos del Derecho Internacional son los Estados-Nación y no los sujetos individuales “
} 
Estados y a las organizaciones internacionales y, excepcionalmente, a los individuos." (Garcés Ávalos, 2016) Interpreta la obra de Álvarez Londoño de la siguiente manera:

(El DIP $){ }^{16}$ Comprende un conjunto de normas jurídicas que regulan las relaciones internacionales, y de normas prescriptivas o permisivas que condicionan dichas relaciones. Este orden normativo procura la coexistencia pacífica y satisfacción de intereses comunes entre las naciones contraponiéndose a la anarquía en las relaciones internacionales.

Tradicionalmente al DIP se le conoce como Ius Gentium (Derecho de Gentes), termino surgido en la antigua Roma, el cual era aplicado para las personas que no fueran ciudadanos Romanos. El ámbito de aplicación de este Derecho era para las personas pertenecientes a pueblos organizados políticamente. Sin embargo, para (Rodríguez Carrión, 2006) el Ius Gentium se asemeja más al Derecho Internacional Privado, razón por la cual éste debería ser considerado como su antecedente y no del DIP. Para este autor, el Ius feciale, que versaba sobre leyes relativas a las embajadas, los tratados y el Derecho de la guerra, sería el antecedente con mayores semejanzas al DIP.

Como una de las críticas que se le realiza al DIP, y que a criterio nuestro no se le pueden realizar el $\mathrm{DI}^{17}$ es la carencia de una autoridad internacional dotada con el poder legal para imponer nuevas reglas vinculantes sobre todos los Estados, así como hacer cumplir las soluciones de controversias entre los mismos, esta carencia de instituciones fuertes y cargadas de un poder real, fortalece "la libertad" de los Estados de acatar o someterse a las normas y soluciones de controversia del Derecho Internacional Público según sus intereses (Pastor Ridruejo, 2012; Lauterpacht, 1970).

\footnotetext{
${ }^{16}$ Es un agregado propio para poder comprender mejor la cita.

${ }^{17}$ Se sostiene que por las propias características del DI, las cuales se desarrollarán seguidamente al presente punto, estas críticas no se le pueden aplicar, ya que este se basa en el deseo de los Estados por constituir una nueva entidad sobre la cual se integran, es decir, se crea un nuevo ser jurídico que asume una personalidad diferente a los Estados que la componen. El poder, las formas, campos y alcances de cómo este será ejercido por la nueva entidad jurídica sobre la cual los Estado se integran, quedará delimitada en el Tratado Fundacional mediante el cual estos cederán parcelas de su propia soberanía hasta el extremo y nivel de integración que estos estén dispuestos a pactar. Por estas características es que se considera al DI más semejante al Derecho Constitucional que al DIP, ya que el Tratado Fundacional, por sus características se asemeja más a una Constitución, y los Estados a los miembros de una comunidad que fundan un Estado, ya que este ejercicio de ceder soberanía a una entidad que regulara la existencia de los individuos que la componen, se asemeja al Pacto Social o al Contrato Social, teorías fundamentales del Constitucionalismo y de la Teoría del Estado.
} 
Asimismo, (Maestre, 2007, p. 316) siguiendo en la misma línea señala lo siguiente,

Ahora bien, contrariamente a lo que dejan imaginar los sueños idílicos de los enciclopedistas, no existe la "sociedad general", un espacio social universal, provisto de gendarmes que garantices la aplicación de una ley planetaria. La única regla de comportamiento internacional es, pues, la libertad, es decir, la ausencia de reglas (la "ley de la jungla"); lo cual equivale a decir que el único principio de comportamiento entre los estados es el nacionalismo. La moral universal se detiene en el umbral de las relaciones internacionales.

Por ello, la jurisdicción de tribunales internacionales es en principio de carácter voluntario por parte de los Estados, incluso en los casos que los Estados se sometan a la jurisdicción de Cortes Internacionales, estas carecen del poder suficiente para poder hacer cumplir sus fallos mediante el uso de la fuerza en caso de desobediencia, como ejemplo de ello encontramos el caso de Colombia contra Nicaragua, en el marco de la Corte Internacional de Justicia de la Haya, la cual le otorgó la soberanía de cierta cantidad de kilómetros cuadrados a Nicaragua, los cuales habían estado bajo dominio y soberanía de Colombia por muchos años, esta "pérdida" de mar territorial para Colombia significó su retiro del Pacto de Bogotá, por considerar la sentencia contraria a sus intereses y a su integridad territorial, razón por la cual hasta el momento de presentación de la presente investigación, Colombia continua ejerciendo soberanía sobre el mar que la Corte Internacional de Justicia de la Haya otorgó a Nicaragua. Ello encuentra explicación en lo señalado por (Maestre, 2007, p. 316),

Los Estados, al igual que los individuos, tienen esferas en las cuales actúan en función, únicamente, de su voluntad (los derechos negativos); pero, a diferencia de los individuos, los estados no tienen por qué conformarse con un código que les atribuya derechos positivos, por la sencilla razón de que tal código no existe. En efecto, para que el derecho se pueda ejercer, es preciso, necesariamente, que exista un espacio social en el interior del cual la colectividad pueda imponer la aplicación de la ley (éste es, precisamente, el Estado de Derecho).

Otra crítica que se desprende de las características propias del DIP, radica en que las normas consuetudinarias no ofrecen suficiente precisión y claridad deseable -asimismo, adolecen de mecanismos eficaces y lo suficientemente disuasivos para garantizar su cumplimiento, más que la reciprocidad entre Estados-, mientras que la norma escrita cuenta con unámbito 
de aplicación mucho más restringido y la cual solo afecta a las partes que se consienten en obligarse $^{18}$, introduciendo así cierta dosis de relativismo y de discrecionalidad en el Derecho Internacional para los destinatarios y creadores de esta rama del Derecho (Garcés Ávalos, 2016; Pastor Ridruejo, 2012).

No obstante, seria mezquino negar el aporte e incluso logros del DIP dentro de las relaciones entre Estados a lo largo de la historia. Si partimos de la premisa que el DIP surge como un mecanismo jurídico para restablecer el equilibrio entre Estados después de situaciones de guerra, se observa que este en un primer momento sí logró por periodos considerables de tiempo, cumplir y mantener dichos objetivos. Sin embargo, por las mismas falencias que se han señalado anteriormente, es que no se pudo mantener el equilibrio logrado frente a nuevos procesos históricos que terminaron por romperlo.

Como ejemplo a este último punto se puede apreciar con la Segunda Revolución Industrial, la cual con la aparición de nuevas fuentes de energía tales como el petróleo, la electricidad, y el desarrollo de nuevas tecnologías así como la aparición de nuevos insumos industriales tales como el acero o el caucho, que llevó a que los Estados impulsaran un nuevo imperialismo; es decir, la búsqueda de nuevos territorios de ultra mar capaces de suministrar las materias primas suficientes para sostener los procesos productivos que estos venían teniendo. Al surgir una nueva forma de competencia y por ende nuevos intereses y necesidades por parte de los Estados, es que este "equilibrio" alcanzando gracias al DIP se vio debilitado y finalmente resquebrajado creándose una serie de tensiones y conflictos que terminarían por contribuyendo sobre manera a que se diera la Primera Guerra Mundial ${ }^{19}$

Frente al gran fracaso que significó para el DIP la Primera Guerra Mundial, puesto que esto puso en manifiesto las grandes debilidades de este, surgió un nuevo enfoque filosófico en

\footnotetext{
${ }^{18}$ Esta última característica es común con el DI, ya que la obligatoriedad de la norma comunitaria es únicamente exigible entre los Estados miembros del Organismo Supranacional, la diferencia - y el por qué se considera una debilidad o crítica al DIP- radica en el sentido universal que el DIP posee, mientras que este aspira a un alcance global entre y para todos los Estados y Sujetos del DIP, el DI no tiene una naturaleza universalista ni un alcance global, sino constitutiva entre todos aquellos Estados que se involucran en un proceso integrador creando un OS, con normas comunitarias exigibles únicamente entre los Estados miembros.

${ }^{19}$ No se puede negar que después de Augsburgo y Wesfalia hayan existido guerras, tales como las guerras napoleónicas o la guerra franco - prusiana; sin embargo, a opinión nuestra, la Primera Guerra Mundial termina siendo el hecho histórico que mayor impacto y debilitamiento generó en el DIP desde su surgimiento hasta los inicios del siglo XX, razón por la cual el Idealismo terminó siendo el nuevo enfoque filosófico que fortaleció y contribuyó a su resurgimiento.
} 
las relaciones internacionales que, a opinión nuestra, sería una nueva bocanada de oxígeno para el DIP, el "idealismo" con los 14 puntos de Wilson, como ente rector de las Relaciones Internacionales.

\section{a) El Idealismo en las relaciones internacionales, influencia en el Derecho Internacional Público}

Antes de continuar desarrollando la idea de los 14 puntos de Wilson, es deber definir y desarrollar el concepto de Idealismo dentro de los cánones de las relaciones internacionales, las cuales sirven como pilar fundamental para el DIP y el DI.

El idealismo es uno de las principales corrientes políticas filosóficas del pensamiento occidental clásico. Uno de los primero y más importantes filósofos clásicos que sirvieron como punto de partida para el desarrollo de esta corriente, fue Aristóteles, quien en su obra "Ética Nicomaquea" sostiene que el ser humano es un ser social por naturaleza y que, a través de las virtudes del mundo de las ideas, los hombres actúan con ética. Justamente es a través de la ética que se busca alcanzar la justicia como la mayor de las virtudes (Axelrod, 1994).

De esta forma, se halla un primer componente moral, es decir la práctica de las virtudes y la conducta ética, como medio para alcanzar la justicia, entendida esta última como un fin que nos lleva a una convivencia armoniosa entre individuos (Axelrod, 1994).

Al ser la justicia, el fin que garantiza la vida en sociedad de manera pacífica y civilizada, los idealistas parten de este concepto y lo llevan a las relaciones entre Estados, es decir, para los idealistas, las relaciones internacionales tienen que regirse por componentes éticos, que garanticen la paz entre estos, ya que:

Desde sus orígenes, los idealistas rechazaron la idea de que los conflictos eran una condición natural de las relaciones entre Estados y que sólo podían ser superados mediante el equilibrio de políticas de poder y la formación de alianzas en contra de las naciones que amenazaran el orden mundial (Jiménez González, 2009). 
Para alcanzar dicho objetivo, los idealistas apostaron por la existencia de una organización internacional que hiciera cumplir la paz (Henry, 1904) esta idea fue esbozada por Dante Alighieri en su obra "De Monarchia" a mediados del siglo XIII (Alighieri, 1996).

Ya para mediados del siglo XVII se vuelve a destacar la necesidad de construir instituciones internacionales capaces de contener a los Estados, para de esa forma mantener la paz y el orden internacional. Dentro de los principales teóricos que apostaron por la idea de una Confederación o Liga de Estados fueron Jean Jacques Rousseau, Jeremy Bentham e Immanuel Kant -este último es considerado como uno de los grandes idealistas de la ilustración y en su obra "La Paz Perpetua" (Kant, 1985, p. 16) ${ }^{20}$, esboza la creencia de que la razón otorgará libertad y justicia a las relaciones internacionales, requiriéndose para ello la transformación de la conciencia individual, el constitucionalismo republicano y un "acuerdo" o tratado federal entre estados para abolir la guerra. Si bien el idealismo persigue un fin sumamente necesario, su mayor debilidad radica en que toma acertadamente el diagnostico esbozado por Aristóteles de reconocer que por medio de la razón se puede alcanzar una conducta ético-moral que lleve a la paz, pero desconoce dos elementos distorsionadores inherentes a la naturaleza humana, que son la libertad y el egoísmo. Ya que todos los individuos pueden estar en la capacidad de razonar para reconocer lo moralmente correcto; sin embargo, el egoísmo y la libertad serán los elementos determinantes que finalmente decidan si se ciñen a lo moralmente correcto, en perjuicio de los intereses individuales, o si se satisfacen éstos a costa de lo ético y del bienestar común, independientemente de las consecuencias que estas pueden tener para la sociedad.

El idealismo parte de premisas incompletas, que dan una interpretación bastante limitada de la realidad. En primer lugar, el hombre por su capacidad de razón puede someter sus instintos e impulsos y basar su conducta sobre la moral y la ética. En segundo lugar, se observa que los idealistas, en la corriente de las relaciones internacionales, llevan este criterio a los Estados en donde si los Estados se relacionan con ética y moral se podrá alcanzar la paz. Y en tercer y último lugar, que para que esa paz sea duradera, deberá existir una organización internacional nacida de la voluntad de los Estados de obedecerla -por razones "éticomorales"- para que vele y garantice la misma.

${ }^{20}$ Traducción de Joaquín Abellan. 
A modo de síntesis, se puede decir que el gran aporte del idealismo para todas las ciencias sociales - Derecho, Relaciones Internacionales, entre otras- es apelar a la razón para poder alcanzar una conducta ético-moral en aras de alcanzar la justicia y el bienestar común, pero la gran omisión, y por ende la mayor debilidad de esta corriente político-filosófica, es desconocer u omitir la naturaleza libre y egoísta de los individuos que anteponen sus intereses por encima del bien común y de la justicia.

Habiendo explicado y valorado al idealismo, no se puede negar la influencia de este en el nacimiento del DIP y del DI; ya que ambos surgen como respuestas a la guerra, caos y desorden en el escenario internacional; Sin embargo, se percibe una mayor influencia y por ende una mayor relación entre el idealismo y el DIP contemporáneo, ya que este apela al pensamiento aristotélico -un raciocinio ético moral que lleve a la "moralización" de las relaciones internacionales- para alcanzar la paz.

Por todo lo antes mencionado, el gran aporte de Wilson y sus 14 puntos, es que a través de estos se logra por primera vez en la historia de la humanidad, crear una organización internacional - como la esbozada por Alighieri, Kant, entre otros- de alcance mundial que "sirva" para garantizar la paz: La Sociedad de Naciones.

¿Por qué nos referimos al Idealismo y a los 14 puntos de Wilson como elementos que fortalecen al DIP? Porque es a partir de las experiencias y fracasos ${ }^{21}$ previos, que en aras de evitar volver a repetirlos, es que comienza a introducirse elementos morales e idealistas dentro del DIP, como ejemplo a ello, se puede encontrar en el punto 1 de los mencionados 14 puntos en donde se observa como elemento moral que se añade a la transparencia y honestidad - buena fe- entre Estados orientándose a los tratados o convenios que estos suscriben "Punto 1. Convenios abiertos y no diplomacia secreta en el futuro". Téngase presente que en el Derecho Diplomático y en las relaciones internacionales hasta la segunda mitad del siglo XX, era una práctica común el mantener tratados secretos -incluso para los nacionales de un Estado-, con este punto, se observa un primer intento por transparentar dentro del escenario internacional los acuerdos y tratados para evitar las desconfianzas y recelos entre Estados.

\footnotetext{
${ }^{21}$ Se considera el término fracaso, ya que, si el fin del DIP es garantizar la coexistencia y mantener el equilibrio en las relaciones entre Estados, toda guerra o enfrentamiento armado es una falla en alcanzar y garantizar dicha finalidad.
} 
Estos componentes "idealistas" terminan aportando un elemento disuasivo que apela a la moral, el "deber ser", "el deber moral" de cumplir lo "pactado" por los Estados, basando dicho cumplimiento sobre la base de una visión idealizada de la comunidad internacional como no existen instituciones con el suficiente poder para legislar y hacer acatar las normas existentes de manera eficaz y pronta, es que los Estados se comprometen a cumplirlo por un deber moral- y trascendental del acuerdo entre los Estados.

Como ya se mencionó al inicio del presente punto, uno de los grandes aportes del idealismo, como corriente político-filosófica de las relaciones internacionales, y de los 14 puntos de Wilson, fue la creación de un organismo internacional, ello reflejado en el Punto 14. "La creación de una asociación general de naciones, a constituir mediante pactos específicos con el propósito de garantizar mutuamente la independencia política y la integridad territorial, tanto de los Estados grandes como de los pequeños". La cual dieron como nacimiento a la Sociedad de Naciones, primer intento tangible y de amplia gama -aunque con grandes ausencias políticas que terminaron por debilitarla, tales como la no incorporación de Estados Unidos, principal promotor de la creación de la misma, o el relegar por muchos años a potencias por cuestiones ideológicas tales como la URSS o a Alemania- que no logró mantener y garantizar la paz por muchos años.

A pesar de la ausencia de un órgano lo suficientemente fuerte para imponer orden, tales como un legislador universal e instituciones que posean los mecanismos que garanticen y velen por el fiel cumplimiento de las normas del DIP, esto no significa que carezca del carácter imperativo esencial a toda ley y derecho, ya que en ciertos sectores de la convivencia internacional existen niveles de observancia y acatamiento muy considerables a lo largo de casi toda su historia, referente a puntos tales como el respeto a la soberanía territorial de los Estados, el cumplimiento de los tratados y normas sobre misiones y agentes diplomáticos (Garcés Ávalos, 2016) ${ }^{22}$.

¿Cómo se explica el alto grado de respeto por parte de los Estados a la norma y costumbre difundida desde Westfalia en los ejemplos del cumplimiento de los tratados y normas sobre

\footnotetext{
${ }^{22}$ Sin perjuicio de lo señalado por Garcés Aválos, se discrepa en lo concerniente al punto de a la integridad territorial, ya que al día de hoy se puede observar una serie de violaciones, tales como los bombardeos estadounidenses en la guerra civil siria, sin que exista autorizaciones expresa de las Naciones Unidas o del gobierno sirio, la invasión de Iraq por parte de Estados Unidos y alguno de sus aliados en el marco de la guerra contra el terrorismo, la cual tampoco contó con la autorización de las Naciones Unidas, entre otros ejemplos.
} 
misiones y agentes diplomáticos? Este alto grado de respeto y cumplimiento se logra no por los fines idealistas o morales de apego al "deber ser" (porque si esta fuera la verdadera causa, todos los ámbitos del DIP funcionaria a la perfección, hecho que no sucede en la realidad), sino que esta responde a la convergencia común de intereses de los Estados, a los que les conviene que respeten a sus misiones y agentes diplomáticos, ya que por más poderoso o grande que sea el Estado, ninguno está en la capacidad de poder asegurar la propia integridad de sus misiones y agentes diplomáticos alrededor de todo el mundo ${ }^{23}$.

El punto más sólido en lo que respecta al carácter imperativo y de cumplimiento y efectividad del DIP, no se basa en el fin idealista o moral que tanto lo fortaleció en el siglo XX hasta la actualidad, sino a un fin práctico y de interés por parte de los Estados, es decir un fin "realista", convergencia de intereses. En la medida que estos concuerden y converjan serán aplicados y respetados. Este último punto es lo que termina siendo la principal fortaleza del DI, el carácter "realista" materializado en la convergencia de intereses de los Estados y el deseo de sus miembros por integrarse.

Por otro lado, a lo más que puede aspirar el Derecho Internacional es a que los Estados cooperen, que es la forma de coexistencia más positiva dentro de la idea de que sigan actuando como entes soberanos que no reconocen una fuente de normas superior a ellos mismos (Robles Morchón, 1996, p. 30).

A modo de conclusión del presente punto, se puede señalar que la principal utilidad y hasta fortaleza del DIP, es que ayuda a ordenar el escenario internacional después de un periodo de caos o guerra, muestra de ello se observa en toda la serie de conflictos armados desde Augsburgo, hasta la Segunda Guerra Mundial, donde justamente es después de estos conflictos en la historia del DIP, donde se encuentran los momentos icónicos del mismo; sin embargo, estos mismos conflictos se han seguido repitiendo a lo largo de la historia, ya que al no existir un mecanismo coercitivo que mantenga o garantice la cooperación y la paz entre Estados - en vista que los intereses que los unen son cambiantes -, es que finalmente el DIP solamente es un mecanismo que organiza el escenario internacional tras tiempos de guerras o crisis, mas no es garantía de manutención del orden obtenido, por justamente la volatilidad

\footnotetext{
${ }^{23}$ Como muestra de ello se puede mencionar el atentado al Consulado estadounidense en Benghazi - Libia, con la muerte del embajador acontecido en el año 2012, o el asesinato del embajador ruso en Turquía en el año 2016.
} 
de los intereses de los Estados, así como falta de mecanismo coercitivos antes señalados, poniendo en evidencia la gran debilidad y fracaso del DIP como herramienta para preservar y garantizar una paz duradera y perpetua, ideal que, por este medio, es utópico.

\subsection{EI Derecho de Integración como rama independiente del Derecho}

Habiendo ya desarrollado la primera posición referente a la relación de subordinación entre el DI con el DIP, se pasará a desarrollar la que sostiene la independencia del DI como una rama del Derecho en sí misma.

Otro sector del mundo académico defiende la tesis que sostiene que por sus propias características, desarrollo y alcances el DI es una rama del Derecho en sí misma - como lo es el Derecho Penal, el Derecho Civil o el Derecho Administrativo-, y no una sub-rama del DIP, todo ello, sin dejar de reconocer el vínculo de origen común entre el DIP y el DI basados en los tratados.

Acorde con (Robles Morchón, 1996, p. 29):

$\mathrm{Al}$ ser el tratado el típico instrumento normativo del Derecho Internacional público, necesariamente se habría de incardinar el Derecho Europeo ${ }^{24}$ dentro del marco del marco de este último. Bien es cierto que una vez constituidas las Comunidades, se penetra en una dimensión diferente a la internacionalista, al haberse constituido una entidad jurídica cualitativamente diferente del resto de los ordenamientos jurídicos existentes, incluido el ordenamiento jurídico internacional. Nos parece, por eso, más ajustado decir que la Comunidad tiene un origen internacionalista (habida cuenta de que surge mediante tratados), pero no que el Derecho Comunitario sea una parte o expresión del Derecho Internacional, sino que constituye un ordenamiento jurídico diferente. El Derecho Comunitario no es Derecho Internacional.

José Manuel Sobrino Heredia, en su artículo "Algunas consideraciones en torno a las nociones de Integración y de Supranacionalidad”, establece que el Derecho de Integración es una institución jurídica nueva con características propias que nace al finalizar la Segunda

\footnotetext{
${ }^{24}$ Por Derecho Europeo el autor se refiere al Derecho Comunitario, especie de Derecho Integración.
} 
Guerra Mundial como resultado de relaciones interestatales con objetivos en conjunto que iban de la mano de la cooperación entre Estados en materia económica, social, cultural o política (Sobrino Heredia, 2001).

De antemano, se observa que para muchos juristas entendidos y especializados en la materia, coinciden en que el DI nace en Europa en el siglo XX; no obstante, existen posiciones que difieren en el momento exacto, ya que un sector considera que este nace antes de la Segunda Guerra Mundial con el Congreso Paneuropeo de Viena de 1926, el cual habla ya no de Europa como un espacio geográfico, sino como un conjunto de valores que confirman una entidad común (Mammarella \& Cacace, 1998). Sin embargo, esta idea representó solo el pensamiento de grandes individuales, pero era ajena o desconocida para las élites gobernantes (Falcón, 2012, p. 13).

Continuando en esa línea previa a la Segunda Guerra Mundial,

En 1929, el Ministro del Exterior Francés Aristide Briand propuso la Federación Europea, en el marco de una sesión de la Sociedad de Naciones, pero su proyecto nunca fue estudiado con profundidad. El ambiente mundial no era propicio a la integración debido a la crisis de Wall Street, a la Conferencia de Londres de 1933 que so pretexto de la estabilización monetaria, permitió el aumento de las tarifas de Estados Unidos y Gran Bretaña diezmando el comercio mundial, y al intento de las potencias coloniales de mantener sus privilegios. Dicho contexto desanimó los proyectos de integración y el movimiento que nació en 1926 quedó prácticamente archivado en 1935 como prólogo del desastre que se avecinaba ${ }^{25}$ (Falcón, 2012,p. 14).

Por otra parte, otros autores consideran que el nacimiento de esta institución jurídica nueva, se da en el contexto de la Segunda Guerra Mundial, tomando como puntos de partida la fundación del BENELUX ${ }^{26}$ en 1944, El Plan Marshall en 1947²7, la Organización Europea

\footnotetext{
${ }^{25}$ Dicho desastre hace referencia a la Segunda Guerra Mundial.

${ }^{26}$ Es el acrónimo formado por las primeras letras de los nombres de los tres países que lo componen: Bélgica, Países Bajos (Nederlan en neerlandés) y Luxemburgo.

${ }^{27}$ Fue una iniciativa de los Estados Unidos para financiar la reconstrucción de Europa tras la Segunda Guerra Mundial, con la finalidad de ampliar su esfera de influencia dentro del viejo continente y contener la expansión del comunismo en Europa Central y Occidental, todo ello condicionado a que los Estados trabajaran y cooperasen conjuntamente.
} 
de Cooperación Económica (OECE) en 1948, el Consejo de Europa de 1949, de cuyo marco se suscribió en 1950 el Convenio Europeo de Derechos Humanos y Libertades Fundamentales, de cuya protección se haría garante al Tribunal de Derechos Humanos de Estrasburgo y finalmente la Comunidad Europea del Carbón y Acero (CECA) de 1951 (Robles Morchón, 1996, pp. 6-7; Falcón, 2012, pp. 15-16).

Como se puede apreciar, si bien no existe un punto de partida uniforme sobre cuándo se inicia el DI, los autores coinciden en el origen europeo del mismo y en el siglo XX como periodo histórico en el cual este se desarrolla. Asimismo, consideran al proceso integrador europeo en sus múltiples fases (CECA, COMUNIDAD EUROPEA, EURATOM, UNION EUROPEA, entre otros) como el nacimiento formal del DI y al Derecho Comunitario Europeo como su consolidación ${ }^{28}$.

El autor del artículo, "El Derecho Comunitario: concepto, naturaleza y caracteres”, Orlando Guerrero Mayorga, hace una reflexión sobre el DC, siendo una forma más desarrollada que el Derecho de Integración, pero básicamente siguiendo los mismos lineamientos. Guerrero Mayorga señala que el DC viene a ser la manifestación más importante de integración entre Estados, ya que este goza de un sistema mucho más complejo que una simple cooperación entre países. Finalmente, culmina su ensayo afirmando que el DC, como instrumento del DI es un concepto autónomo, ya que goza de ordenamiento normativo y de aplicabilidad inmediata en el tiempo, en cuanto se convierte vinculante para la normativa interna de los Estados (Guerrero Mayorga, 2005).

Con ello no hay que olvidar que el DC tiene su origen dentro del DIP, debido a que los tratados fundacionales nacen bajo el régimen de este último. Sin embargo, es con la creación de los órganos supranacionales que aquel se independiza progresivamente del DIP, a pesar de que todavía habrá una vinculación respecto al tratado fundacional, relación similar a la de la Constitución con las normas inferiores y subordinadas (Dromi, Ekmekdjian, \& Rivera, 1996, p. 71).

Pero en cuanto a dicha independencia progresiva, es necesario mencionar que el DC no se compone únicamente de normas de DIP, sino que se integra también por otras normas de

\footnotetext{
${ }^{28}$ Sin perjuicio de lo antes mencionado y para los fines de la presente investigación, se considera el proceso de integración germánico en sus múltiples fases (Confederación Germánica (1815 a 1870) y II Reich) como nacimiento y consolidación del DI.
} 
fuentes distintas a este último, como es el caso de los reglamentos, directivas, decisiones, etc., por lo que su dependencia del DIP, se halla únicamente en sus normas constitutivas (tratados), mas no en su desarrollo (Ortiz Ahlf, 2003, p. 16).

Tal es el caso, por ejemplo, del Derecho de la Comunidad Andina, el cual carece de influencias del Derecho Internacional Público en cuanto a su desarrollo y funcionamiento, a pesar de que sí es posible una vinculación entre ambos sistemas jurídicos (Carruitero Lecca, Gutíerrez Canales, \& Torres Lobato, 2005, pp. 48-49). Del mismo modo, se puede afirmar que la existencia de órganos de creación normativa en las organizaciones supranacionales configura un rasgo a tomar en cuenta respecto a la justificación de su autonomía (Novak Talavera, 2003, pp. 57).

Alberto Zelada Castedo afirma que constituye un "sistema normativo autosuficiente en el sentido de que contiene en sí mismo todos los elementos para su desarrollo, interpretación y aplicación". Menciona, además, que, si bien se basa inicialmente en el DIP, su posterior desarrollo tiene como fundamento actos de naturaleza eminentemente distinta (Zelada Castedo, 1989, p. 24).

Por otra parte, (Molina del Pozo, 1990) opina que el DC es un conjunto de reglas que determinan la organización, las competencias y el funcionamiento de las Comunidades Europeas, y que ha sido el TJC quién ha declarado que este Derecho supone un orden jurídico propio, que se diferencia del orden jurídico internacional y que, también, es distinto del orden jurídico interno de los Estados miembros. Es precisamente ese orden jurídico propio, distinto del internacional y del interno de cada Estado miembro, lo que se denomina Ordenamiento Jurídico Comunitario.

Acorde con (Ortiz Ahlf, 2003, p. 14):

El Tribunal de Justicia de las Comunidades $^{29}$ Europeas ha recordado continuamente el carácter propio, nuevo y autónomo del derecho comunitario, como un ordenamiento legal separado del derecho internacional y del derecho nacional, comenzando con la sentencia del Caso Gend and Loos en 1963 y Costa V. Enel en 1994 en las cuales los jueces, describieron el Tratado de la Comunidad Europea como un tratado de naturaleza especial.

${ }^{29}$ También conocido como Tribunal de Justicia Comunitario - TJC, o Tribunal de Justicia de la Unión Europea 


\subsubsection{Características del Derecho de Integración}

Para señalar las características del DI, no se puede dejar de seguir señalando las diferencias de este en relación al DIP, con la salvedad que, en esta oportunidad, las diferencias señaladas seguidamente no se basaran en elemento jurídicos, sino en las relaciones entre los Estados dentro de cada tipo de Derecho y los efectos jurídicos que estos terminan generando.

Según lo señalado por (Robles Morchón, 1996, p. 29):

Mientras que el Derecho Internacional es el Derecho típico de la coexistencia o cooperación, el Derecho Comunitario es el Derecho de la integración. La diferenciación de estos tres conceptos es importante, pues nos proporciona la clave de la distinción del carácter del Derecho Comunitario con respecto al Derecho Internacional. ${ }^{30}$

Las tres palabras antes resaltadas, denotan tres niveles de interacción entre los Estados, los cuales parten de una menor a mayor intensidad. Para ello se analizará cada una de ellas.

\section{a) Coexistencia:}

Según la (Real Academia Española, 2016) es la existencia de una persona o de una cosa a la vez que otra u otras. Es decir, la existencia conjunta de varios elementos a la vez.

Llevando este término al campo de las relaciones internacionales, se puede entender como

<<existir con〉>, <<existir al lado de〉>, sin que ese existir exija un esfuerzo especial de colaboración; simplemente se convive en una relación más o menos armoniosa. La coexistencia entre Estados es la meta mínima, y por eso mismo esencial, del Derecho Internacional. Cuando la coexistencia pacífica se deteriora y aparece el conflicto, allí está el Derecho Internacional para intentar que la paz se restablezca. El Derecho Internacional, en esta acepción primaria, no se propone otra meta que regular la paz y la guerra (y, en general, los conflictos entre los sujetos de Derecho Internacional, que principalmente son los Estados) (Robles Morchón, 1996, p. 30).

\footnotetext{
${ }^{30} \mathrm{El}$ resaltado es propio.
} 


\section{b) Cooperación:}

Según la (Real Academia Española, 2016) se hallan dos definiciones:

\section{1. f. Acción y efecto de cooperar.}

Es decir, operar, actuar con otra persona o cosa de manera conjunta.

Llevando este término al campo de las relaciones internacionales,

La cooperación implica un paso más en la dirección de la buena convivencia. Para que los Estados cooperen, no sólo han de coexistir, existir uno al lado del otro, sino que además han de proponerse metas comunes y realizar acciones comunes o coordinadas para alcanzar esas metas. La cooperación implica no una actitud pasiva (como ocurre en la mera coexistencia) sino activa; los cooperantes se aproximan entre sí en cuanto que realizan actividades para conseguir una meta común (Robles Morchón, 1996, p. 30).

\section{c) Integración:}

Según la (Real Academia Española, 2016) es la acción y efecto de integrar o integrarse. Es decir, la acción de fusionarse, hacerse uno, constituirse.

Llevando este término al campo de las relaciones internacionales, se puede entender como el nivel más elevado de interacción entre Estados y que termina teniendo un efecto jurídico pleno, materializado en la creación de un nuevo ser jurídico: El Organismo Supranacional.

En ella los agentes participantes no sólo cooperan, sino que crean una entidad nueva en la que se integran, un nuevo ser jurídico que asume una personalidad distinta a la de los Estados que han acordado crearla; esa nueva entidad se propone la realización de determinadas acciones o políticas que los Estados no pueden ya realizar por sí mismos independientemente, puesto que han acordado que sea la nueva entidad la que asuma ese papel. Mientras que en la cooperación los Estados siguen siendo ellos mismos los que actúan cooperando, en la integración es el nuevo ente el sujeto de las acciones, si bien es cierto que el nuevo ente puede ordenar acciones a los Estados miembros; pero, en todo caso, lo relevante es que 
éstos no son los sujetos últimos de las decisiones adoptadas (Robles Morchón, 1996, p. 30).

De esta forma el DC aspira a algo superior a solo la cooperación, ya que desde el momento en que el OS impone sus decisiones a los Estados que lo componen para estos actúen como una sola unidad, como un bloque, dichas acciones conducen a alcanzar las metas propuestas en el Tratado Constitutivo.

Habiendo definido a la Integración como el nivel más elevado de interacción entre Estados, cuyos efectos jurídicos se materializan en el OS, es necesario analizar los medios jurídicos -la aplicación del DI- que contribuyen a alcanzar dichos efectos.

Para ello, es necesario entender que el DI nace de la voluntad de los Estados por elevar sus relaciones bilaterales o multilaterales al nivel antes mencionado. Es decir, la primera característica del DI, es que este nace de la libertad de los Estados por querer alcanzar una integración con otros, en las formas, campos y alcances que éstos deseen y determinen ${ }^{31}$. Sin que exista una delimitación específica sobre la cual éstos se integren, mas sí existe una característica fundamental para que un proceso de integración sea reconocido formalmente como tal: la cesión de soberanía.

\section{d) La Cesión de Soberanía}

Antes de seguir desarrollando el presente punto, es oportuno explicar qué es la soberanía. Como una de las primeras definiciones sobre qué es la soberanía, se puede encontrar en "El Príncipe" de (Maquiavelo, 1978), quien sostiene que la soberanía se constituye, así como un poder superior configurado como un derecho del príncipe, derecho cuya primacía funda la unidad jerárquica del poder del Estado, «lo stato».

Sin embargo, sería Jean Bodin o Bodino (1530-1596), el cual en su obra Los Seis Libros de la República desarrollaría mejor este término, definiéndola como el poder absoluto defendiendo así también a la monarquía absoluta-, poniéndole como límites la Ley Natural y los bienes propios de la familia, siendo esta indivisible e incomunicable y no estando sujeta a herencia (Andrew, 2011; Wilson, 2008; Bodin, 2006; Maritain, 2002, pp. 43-51).

\footnotetext{
${ }^{31}$ Pudiendo ser comerciales, defensivas, económicas, políticas, aduaneras, entre otras.
} 
Acorde con (Garcés Ávalos, 2016) sobre Bodin.

Si bien muestra favorecer al sistema monárquico, Bodin también analiza otros tipos de gobierno como la democracia y la aristocracia, enfatizando que lo verdaderamente esencial es la forma de gobernar, a diferencia de Maquiavelo, para quien lo fundamental radica en la conservación del poder.

Asimismo, (Novak Talavera \& García-Corrochano Moyano, 2000, p. 371) señalan sobre Bodin y soberanía lo siguiente:

El término soberanía fue introducido por Bodin en su obra publicada en 1577, titulada "Los Seis Libros de la República", entendida como la suprema potestad o summun imperio del soberano sobre el territorio y los habitantes sin ninguna restricción, excepto los mandamientos de Dios y el derecho natural. Ninguna constitución podía limitarla, ya que era un atributo del rey en una monarquía y del pueblo en una democracia.

Finalmente (Verdross, 1978, p. 9) señaló que Bodin definía la soberanía estatal como el poder supremo sobre los ciudadanos y súbditos, independiente de las leyes positivas.

La importancia de Bodin, radica en que es uno de los primeros pensadores, sino el primero, en desarrollar el concepto de soberanía, por ello, la importancia de mencionar a otros autores que analizan y estudian la obra de este pensador francés puesto que es un referente sobre la materia.

No obstante, también existen definiciones realizada por autores contemporáneos los cuales se mencionarán a continuación.

Como un primer ejemplo, se encuentra a los profesores (Novak Talavera \& GarcíaCorrochano Moyano, 2000, p. 372), quienes consideran que

La soberanía comprende consecuentemente el derecho del Estado de determinar su sistema político, social y económico sin injerencia externa; el derecho de dominio sobre su territorio (territorio terrestre, mar territorial y espacio aéreo), manifestación de la soberanía conocida como soberanía territorial; el derecho de aplicar su ley y jurisdicción 
sobre todo su territorio, inclusive sobre las personas y bienes de los extranjeros que residan en él; el derecho de dirigir su política exterior conforme sus intereses nacionales; entre otros.

Krasner (2001, pp. 231-233) encuentra un cuádruple uso del término "Soberanía" con características distintas:

- Soberanía de Interdependencia: Infiere la habilidad del Estado de controlar el movimiento a través de sus fronteras. La soberanía se encuentra en un proceso de erosión por parte de la globalización, dado que los gobiernos han perdido la capacidad de conducir una política monetaria directa (por los flujos internacionales de capital), de controlar la transmisión de conocimiento (por el auge del Internet), y de regular el movimiento transfronterizo de bienes, capitales, personas, ideas, etc. El aspecto principal del presente concepto de soberanía radica no en la autoridad, sino en el control que pueda ejercer el Estado.

- Soberanía Doméstica: Radica en las estructuras de autoridad dentro de un determinado Estado, y su regulación efectiva del comportamiento de quienes lo habitan. Es la soberanía que defendieron Bodin y Hobbes, en tanto buscaron establecer una autoridad que fuese reconocida por la sociedad sin importar afiliación religiosa alguna, centralizándola y negando el derecho de revolución. En este concepto de soberanía, los aspectos importantes son el de reconocimiento de la autoridad como tal, y el nivel de control que sus funcionarios puedan ejercer de forma efectiva. Sin embargo, la globalización ha afectado al presente concepto de soberanía, así como el de la interdependencia, dado que si el Estado -siguiendo el ejemplo de Krasner -es incapaz de controlar el flujo de droga dentro de sus fronteras, no es probable que pueda hacerlo dentro. En la práctica, las ideas de Hobbes y Bodin no han sido aplicadas, y altos niveles de centralización no han devenido en el orden y estabilidad que ambos autores trataron de garantizar en su tiempo.

- Soberanía Westfaliana o Vatteliana: Infiere la exclusión de las fuentes externas de autoridad, sean de iure o de facto (caso de la Iglesia Católica en los s. XVI-XVII). Dentro de sus límites, el Estado posee el monopolio de la toma de decisiones que la autoridad le confiere, y en el ámbito internacional se ve compelido a cumplir la regla de no intervención en los asuntos internos de otros Estados. Se asocia este concepto a 
la Paz de Westfalia (1648) en tanto, a juicio de Krasner, reforzó el principio de cuius regio, eius religio aparecido en Augsburgo (1555). Westfalia estableció un régimen de tolerancia internacionalmente sancionada por las potencias de Europa, más no legitimó la autoridad de los príncipes para establecer prácticas religiosas sobre sus dominios, y por ello no tiene relación alguna con las convencionales nociones de soberanía. Vattel y Wolff, por otro lado, fueron defensores en el s. XVIII del principio de que los Estados no deben inmiscuirse en los asuntos de otros, llegando a criticar en el caso de Vattel -la conquista hispánica del Perú y el juicio del Inca Atahualpa. Para el s. XIX, fue defendido por los jóvenes Estados de América Latina, considerados los más débiles en el sistema internacional de su época, y no fue sino hasta 1930 que Estados Unidos reconoció dicho principio.

- Soberanía Legal Internacional: La presente conceptualización radica en el reconocimiento dado a entidades jurídicamente independientes, con base territorial, y capaces de entrar en acuerdos contractuales, asociando dicho reconocimiento a otras reglas como la inmunidad diplomática, y el acto de doctrina estatal que protege las acciones del Estado frente a cortes extranjeras. El autor señala que el acercamiento convencional del Derecho Internacional es análogo a la Teoría Liberal del Estado, y que los Estados en el sistema internacional, como individuos en la política doméstica, son libres e iguales. La soberanía, por tanto, infiere la habilidad de controlar los movimientos transfronterizos o actividades internas, y las reglas y principios tales como el reconocimiento de entidades jurídicamente independientes.

Si bien el protagonismo de estas relaciones internacionales sigue correspondiendo al Estado, las organizaciones internacionales - a pesar de la soberanía de estos- han influyen en mayor o menor medida en las acciones de estos en el sistema internacional (Villamor MorganEvans, 1999).

Con todo lo antes mencionado, se puede concluir que la soberanía es la manifestación por excelencia del poder estatal, aplicado a sus diversos campos, principalmente dentro de su propio territorio y las personas que habitan dentro de este, así como los actos que estos, unilateral y libremente, realizan dentro del escenario internacional en concordancia con el pleno poder y libertad que ostentan. 
Siguiendo con las características del DI, para que esta cesión de la soberanía estatal se dé, es necesaria la confianza mutua entre las partes, dado que para que los Estados cedan parcelas de esta, las cuales serán posteriormente depositadas en el OS, es necesario un ambiente de no solo cooperación, sino confianza entre estos. De esta manera, con la cesión de parcelas de soberanía en las formas, campos y alcances sobre los que se va a constituir la integración, se constituye la supranacionalidad del OS, y el nacimiento del DC.

El DC supone la renuncia expresa de los Estados miembros, al ejercicio de su soberanía en las materias que estas hayan sido cedidas y acotadas por los Tratados Constitutivos; por consiguiente, dichas materias estarán reservadas exclusivamente para el OS quien dispondrá de autonomía y soberanía propia para actuar en estos campos sobre los Estados que lo componen.

Sin que ello signifique que los Estados dejen de ser entes políticos soberanos, estos han pactado entre sí la renuncia al ejercicio de determinadas parcelas de su soberanía, transfiriéndolas a una nueva entidad los poderes correspondientes.

De ahí que el OS no genere un Derecho interestatal sino un auténtico Derecho interno, que tiene además la característica de que se integra en el Derecho interno de los Estados miembros. El OS es la fuente superior de normas en las materias reservadas por los Tratados, para lo cual dispone de una organización institucional propia que genera su propio ordenamiento jurídico (Robles Morchón, 1996, p. 31).

Sobrino Heredia señala que en la integración los Estados ceden voluntariamente su soberanía, mientras que, en la supranacionalidad, se cede algo más que la soberanía, sino que se traslada está a entes internacionales superiores (Sobrino Heredia, 2001). Para este autor, la supranacionalidad es la consolidación de la cesión de la soberanía estatal recogida en el Tratado Fundacional/y, por ende, elemento constituyente del Organismo Supranacional.

Por ello, y en virtud de lo señalado por (Plata López \& Yepes Ceballos, 2009):

El Derecho comunitario en virtud de su supranacionalidad se constituye en un ordenamiento jurídico propio y especializado, distinto del Derecho interno y del Derecho internacional común, que se inserta en los ordenamientos jurídicos nacionales con valor superior a la ley nacional a la que desplaza o sustituye en 
forma directa y automática (principios de aplicación directa y preeminencia). Existe una ordenación jerarquizada de normas donde las superiores son la Constitución comunitaria y las que ocupan un rango inferior, las derivadas o secundarias $^{32}$, que emanan de los órganos comunitarios. También se reconoce la importancia de estas normas en la conformación del bloque de constitucionalidad. ${ }^{33}$

A modo de síntesis, se hallan como elementos nucleares del proceso integrador en las relaciones internacionales a:

1. La libertad, entendida como el deseo de los Estados por integrarse entre sí, así como la libre determinación en las formas, campos y alcances en los que estos se integrarán.

2. La confianza, las buenas relaciones entre Estados reflejados en la confianza mutua o entre las partes.

3. La cesión de soberanía, entendida como el desprendimiento de la facultad estatal en el ejercicio de su poder natural en en las formas, campos y alcances sobre los que se va a constituir la integración, en beneficio del Organismo Supranacional.

Los cuales en su conjunto conducen al DI para que este termine materializando sus efectos en el Tratado Fundacional y posterior nacimiento del OS, y en el DC.

Finalmente, una característica central del DI y DC es el ámbito de aplicación, elcual marca una clara diferencia con el DIP, ya que en este último los sujetos a los que van dirigidas sus normas son los Estados, excepcionalmente y residualmente a los individuos (en especial en materia de derechos humanos).

En contraste con este rasgo del DIP, los sujetos a los que van destinadas las normas del DC son prioritariamente los individuos que son ciudadanos de los Estados miembros, y en segundo lugar, los Estados mismos. Como el DC es, en su núcleo fundamental, el ordenamiento jurídico comunitario cuyo primer cometido, es la regulación de las relaciones económicas entre dichos agentes; y en segundo lugar, las obligaciones de los Estados en

\footnotetext{
${ }^{32}$ Tales como Reglamentos, Directivas, Decisiones.

${ }^{33}$ Por bloque de constitucionalidad hay que entender la relación de concordancia entre el Tratado Fundacional (Constitución Comunitaria) y las normas derivadas o secundarias (si se aplica la "Pirámide de Kelsen", el Tratado Fundacional (Constitución Comunitaria) sería la punta de la pirámide y las normas derivadas todas aquellas que se desprenden o sostienen dicha punta.
} 
orden a estructurar jurídica y administrativamente el Mercado Común. Por estas razones, en el mismo Preámbulo del Tratado de la Comunidad Europea se alude a la finalidad de "sentar

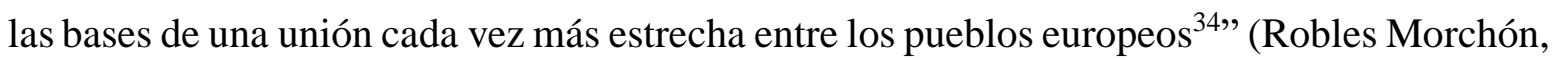
1996, p. 31).

\subsubsection{El Realismo en las relaciones internacionales, influencia en el Derecho de Integración}

Habiendo ya hecho una breve reseña sobre el idealismo, así como su estrecha relación e influencia con el DIP, es importante desarrollar, lo que, a criterio propio, se considera como la real y principal corriente político filosófica que influye en el DI, el realismo.

El realismo, como corriente político filosófica, se puede sintetizar en la siguiente frase "Los Estados no tienen amigos, tienen intereses comunes" ${ }^{35}$. Esto de por sí, nos da una idea del carácter pragmático, e incluso amoral, con la que esta corriente interpreta y conduce las relaciones entre Estados, así como las relaciones de poder entre particulares.

\section{a) Maquiavelo}

Al igual que el idealismo, el realismo tiene influencias de la filosofía de la antigua Grecia; sin embargo, de manera formal se considera que esta corriente nace a mediados del siglo XVI con Maquiavelo con su obra "El Príncipe". No obstante, es pertinente tomar como una especie de "proto realismo", al historiador Tucídides con su obra "La Historia de la Guerra del Peleponeso", en la cual, hace un análisis de las causas y motivos que llevaron a la guerra entre atenienses y espartanos a mediados del siglo V a.C. Para este autor, la causa de la guerra fue el surgimiento del poder de Atenas y el temor que esto produjo en los espartanos y sus aliados, conclusión a la que llega mediante el análisis de las entidades organizadas en territorios (polis griegas) y la premisa fundamental de que estas organizaciones buscan el poder y calculan sus intereses en función de este y tienden a crear alianzas y conflictos en aras de obtenerlo (Jiménez González, 2009).

\footnotetext{
${ }^{34}$ Robles Morchón considera que la referencia a pueblos y no Estados es con la intención de reforzar la idea de unión entre los individuos en tanto estos son los destinatarios finales de las normas del DC.

35 La presente frase es una de las múltiples adaptaciones a la frase original "Las naciones no tienen amigos o enemigos permanentes, solo intereses permanentes" - Lord Palmerston, Ministro de Exteriores británico de 1846 a 1851.
} 
Si bien la obra en cuestión no hace un desarrollo teórico del realismo, la forma a través de la cual narra la historia, así como la descripción antes señalada, resulta ser una aproximación primigenia realista al escenario político internacional de la antigüedad clásica.

Como ya se dijo al inicio del presente punto, el realismotiene como primera gran diferencia con el idealismo, el carácter amoral pero sobre todo pragmático en la forma de conducir las relaciones internacionales y la política en general; ello, porque toma como punto de partida la fractura entre política y moral que plantea Maquiavelo (ya que hasta antes de este ruptura, las relaciones de poder tuvieron una gran influencia aristotélica, pero sobre todo Tomista ${ }^{36}$, la cual constituía la base de la tradición política internacional medieval así como del Derecho Internacional Clásico).

Esa ruptura que plantea Maquiavelo, se comprende en buena parte por el contexto de crisis moral que le tocó presenciar en la sociedad y la política italiana, la cual acorde con (Sabine, 1994, p. 269):

(...) Una sociedad intelectualmente brillante y artísticamente creadora, más emancipada que cualquiera otra de Europa de las trabas de la autoridad y dispuesta a enfrentarse al mundo con un espíritu fríamente racional y empírico, y presa; sin embargo, de la peor corrupción política y la más baja degradación moral. Las instituciones cívicas antiguas estaban muertas; (...). La crueldad y el asesinato se habían convertido en procedimientos normales de gobierno; la buena fe y la lealtad, en escrúpulos infantiles a los que un hombre ilustrado apenas concedería el homenaje de un cumplido de labios afuera; la fuerza y la astucia, en claves del éxito; el libertinaje y el desenfreno eran tan frecuentes que no provocaban comentarios; y el egoísmo franco y desembozado sólo necesitaba del éxito para justificarse.(...) Maquiavelo es, pues de modo muy acusado, el teórico político del "hombre sin amo", de una sociedad en la que el individuo se encuentra solo, sin más motivos ni intereses que los proporcionados por su propio egoísmo.

Como ya se estableció en el acápite del idealismo, el egoísmo es el elemento que finalmente determina la voluntad del hombre de bien ceñirse a la razón de lo moralmente correcto, o finalmente sucumbir a sus propios deseos e intereses. Este elemento, fue correctamente

\footnotetext{
${ }^{36}$ Se le llama Tomista, en honor a Santo Tomás de Aquino, uno de los filósofos, pensadores y teólogo más eminente del cristianismo durante la edad media. Para mayores detalles sobre su figura véase la obra de (Spiazzi, 2004)
} 
reconocido por Maquiavelo como una de las principales motivaciones de las personas y la causa central por la cual el pensamiento Tomista y Aristotélico, no eran del todo exacto en sus planteamientos cuando estos eran contrastados con la realidad. Asimismo, reconoce como características propias de la naturaleza humana la agresividad y la ambición que finalmente terminan por llevar a los seres humanos a aspirar conservar lo que tienen y a adquirir más, hecho que finalmente carece de todo límite, salvo en la limitación natural tanto de los bienes como del poder mismo (Sabine, 1994, p. 273).

Asimismo, para Maquiavelo

Los hombres se encuentran siempre en situación de lucha y competencia que amenaza con degenerar en anarquía abierta a menos que les limite la fuerza que hay tras el derecho, en tanto que el poder del gobernante ${ }^{37}$ se basa en la misma inminencia de la anarquía y en el hecho de que la seguridad solo es posible cuando el gobierno es fuerte (Sabine, 1994, p. 273)

Esta conducta, como bien señala Sabine en la interpretación que hace sobre la obra de Maquiavelo, si bien se aplica a la conducta individual de las personas, no se puede dejar de percibir una gran similitud con las acciones de las diversas organizaciones políticoadministrativas dentro del escenario internacional a lo largo de la historia de la humanidad, las cuales han siempre codiciado y disputado con otras por mejores y mayores cantidades de recursos, así como un mayor poder dentro del territorio que ocupaban.

Es oportuno acotar que, el pensamiento de Maquiavelo, no constituye o fomenta un estado de anarquía y amoralidad dentro de la sociedad, por el contrario, reconociendo esa tendencia natural humana al egoísmo, así como su agresividad por saciarlo, plantea la separación de la moral individual, del accionar del Estado, en tanto que cada uno perseguía finalidades distintas: a la primera se le mide por el vigor que su conducta da a la sociedad, mientras que al Estado se le mide por el mantenimiento del orden y de su poder. ${ }^{38}$ (Sabine, 1994, p. 272).

\footnotetext{
${ }^{37}$ Para efectos y fines de la presente investigación, así como con nuestros tiempos, es más acertado modificar la palabra "gobernante" por "Estado", toda vez que, dentro del mundo occidental, el poder es personificado no en una persona, sino en una "entelequia jurídica" llamada Estado a través de sus diversas instituciones.

${ }^{38}$ En la obra la cita textual hace referencia al gobernante y no al Estado, así como sólo al poder mas no al orden, a interpretación propia, Maquiavelo no separa la idea de gobernante de Estado, mantiene la visión absolutista de que el Estado es el soberano, por ello y acorde con nuestros tiempos, se adapta el pensamiento de Maquiavelo sin que este pierda el sentido original que primigeniamente tuvo.
} 
De esta forma Maquiavelo plantea la idea de un Estado fuerte capaz de contener la naturaleza humana, por medios no necesariamente alineados con la moral de los individuos, pero que finalmente contengan esa naturaleza negativa humana, garantizado el orden y el poder: “ $E l$ fin justifica los medios ${ }^{\prime 39}$.

Para ello Maquiavelo en su obra El Príncipe dirá:

(...) un nuevo príncipe, no puede observar todas aquellas cosas por las cuales son los hombres estimados por buenos, ya que a menudo se verá constreñido, para mantener su Estado a obrar contra su palabra, contra la caridad, contra la humanidad, contra la religión (...) Esfuércese el príncipe, por tanto, en vencer y en mantener su Estado, que los medios serán siempre juzgados honorables y loados por todos (Maquiavelo, 1978).

A modo de síntesis, Maquiavelo es la piedra angular sobre la cual se desarrolla y constituye el Realismo político, tanto para la política local como la internacional, ya que este no parte de un "ideal", un "deber ser", al cual alcanzar, sino parte de una realidad, "el ser", "lo que es": el ser humano como ser egoísta y violento que se encuentra en constante lucha por satisfacer sus pretensiones y deseos, y es sobre estas características innatas de la naturaleza humana, que esboza la idea de "política" como un medio por el cual contener esa naturaleza negativa de las personas, apelando a una separación entre la moral del gobernante $-\mathrm{o}$ el Estado- sobre la moral individual, siendo la separación de moral y política el segundo gran aporte de este. Y finalmente reconoce la importancia del Derecho como el medio por el cual el poder político logra contener el caos y tendencia natural a la anarquía del ser humano, siendo el garante del bienestar y de la vida en sociedad. Por todo ello, es que Maquiavelo termina siendo la piedra angular sobre la cual se sostiene el pensamiento de Thomas Hobbes, filósofo inglés que desarrollará aún más el realismo, a través de su obra "El Leviatán": Este aspecto del pensamiento de Maquiavelo, completado por una sicología sistemática que lo explica y justifica, se convierte en la filosofía política de Hobbes (Sabine, 1994, p. 273; Donskis, 2011; Maquiavelo, 1978)

\section{b) Thomas Hobbes}

\footnotetext{
${ }^{39}$ Si bien esta frase es atribuida a Maquiavelo, en realidad la autoría es de Napoleón Bonaparte, frase que acuñó en su ejemplar de "El Príncipe".
} 
Como ya se señaló, Maquiavelo sienta los pilares sobre los cuales el realismo se irá desarrollando y consolidando como una corriente político-filosófica alterna al idealismo, siendo con Thomas Hobbes, quien desarrollaría y profundizaría aún más lo que en un primer momento planteó este autor italiano. Si bien Hobbes es por excelencia uno de los grandes representantes del Absolutismo, su obra está estrechamente ligada con el Realismo.

Thomas Hobbes fue un filósofo inglés del siglo XVII,

Los escritos políticos de Hobbes fueron motivados por las guerras civiles ${ }^{40}$ y con la intención de ejercer influencia del lado del rey. Estaban destinados a apoyar el gobierno absoluto y a juicio de Hobbes esto significaba la monarquía absoluta (Sabine, 1994, p. 353)

Acorde con (Sabine, 1994, p. 353)

Hobbes fue en realidad el primero de los grandes filósofos modernos que intentó poner la teoría política en íntima relación con un sistema de pensamiento enteramente moderno, y se esforzó por hacer ese sistema lo suficientemente amplio para que pudiera explicar, a base de principios científicos, todos los hechos naturales, incluyendo la conducta humana tanto en sus aspectos individuales como en los sociales.

Hobbes puede ser considerado como uno de los pioneros de llevar el pensamiento clásico a la denominada edad moderna por el uso del método científico, buscando alcanzar una explicación de todo lo relacionado en la conducta humana a través de este método. Así, pues, la filosofía de Hobbes era un plan encaminado a asimilar la psicología y la política a las ciencias físicas exactas (Sabine, 1994, p. 355)

La conducta humana, que comprende la sensación, el sentimiento y el pensamiento, es una forma de movimiento. Y la conducta social, en la que se basa el arte del gobierno, no es sino aquel caso particular de la conducta humana que surge cuando los hombres actúan con referencia a los demás. La ciencia política se construye, en consecuencia, sobre la psicología, y el modo de proceder es

\footnotetext{
${ }^{40}$ La Guerra Civil Inglesa es el término con el que se hace referencia a la serie de conflictos armados y maquinaciones políticas que tuvieron lugar entre los monárquicos y los parlamentaristas desde 1642 hasta el 1651.
} 
deductivo. Hobbes no se propuso demostrar lo que es en realidad el gobierno, sino lo que tiene que ser para poder controlar con fortuna a unos seres cuya motivación es la de la máquina humana (Sabine, 1994, p. 355).

Para Hobbes, el hecho sicológico fundamental era el que todo estímulo afecta la vitalidad de un organismo. Si el efecto es favorable, dicho organismo mantendrá el estímulo y la conducta en aras de asegurar o aumentar su vitalidad, caso contrario, la dejará de lado, puesto que el instinto natural de todo ser vivo es la de asegurar su propia conservación (Sabine, 1994, p. 358).

Frente a este planteamiento de Hobbes, surge la siguiente interrogante, si finalmente la conducta está condicionada por todos aquellos estímulos que son favorables a nuestra vitalidad, y por ende garantizan nuestra supervivencia, ¿qué ocurre con ese egoísmo natural de las personas que muchas veces se contrapone con las necesidades y los estímulos de otras personas? Para Hobbes, el deseo de supervivencia tiene dos dimensiones, una irracional / instintiva o "pre-social", y una racional o "social".

En la primera, el individuo busca por sus propios medios asegurar su supervivencia de forma egoísta e individual, imponiéndose a otros de menor poder; esta forma claramente describe un estado pre-social, más salvaje que a la larga hubiera llevado a la extinción de la raza humana, dado que el ser humano es un ser biológicamente inferior frente a otros seres vivos, y que frente a estas carencias fisiológicas la suple con su inteligencia.

Justamente es este intelecto, lo que para Hobbes lleva a que el ser humano, consciente de lo antes descrito, busque otras fórmulas para garantizar su seguridad y supervivencia, buscando la vida en sociedad como el medio que lo garantice. Para ello, diseña la teoría política por excelencia, para comprender y explicar cómo es que se estructura el poder capaz de gobernar y organizar a estos colectivos de personas: la Teoría del Leviatán ${ }^{41}$, la cual explica que a través del Estado (u organizaciones político administrativas, previas a la existencia del Estado), entidad suprema diseñada para asegurar la coexistencia de las personas que conviven en sociedad, es que se puede lograr el orden y bienestar que garantiza la vida de

\footnotetext{
${ }^{41}$ Hobbes explica que siempre van a existir sujetos más fuertes que otros que van a querer imponer su voluntad por encima de sujetos más débiles. Para este filósofo, el ser humano es egoísta por naturaleza y es necesario una entidad suprema que tenga el monopolio de la fuerza para asegurar la convivencia pacífica (Hobbes si bien es representante del Absolutismo, su teoría es perfectamente aplicable a otros modelos de Estados).
} 
los mismos.

En su conocida obra, El Leviatán (Hobbes, 1940) se le da al Estado una personería propia, lo elabora como un sistema surgido del contrato celebrado entre todos los individuos para poner un alto al estado anárquico y caótico de la naturaleza ${ }^{42}$. Teniendo por esencia el poder y siendo el Estado un ente despersonalizado basado en la legalidad como fórmula de obediencia, Hobbes sostiene que cada ser humano nace con poder, pero lo cede a una entidad superior para que sea esta última la encargada de imponer el orden y asegurar la convivencia entre los demás sujetos. Es el pacto el que legitima al Estado, que busca a su vez evitar el desencadenamiento de una guerra civil o un estado de anarquía (Ramírez Echeverri, 2010).

¿Por qué si todos nacen con poder, se tiene que cederlo a esta abstracción llamada Estado? Porque al existir diferencias naturales entre todos los individuos, existen también distintos grados o tipos de poder y frente al egoísmo natural de todas las personas, el ejercicio y la satisfacción de este, podría llevar a última instancia al fin de la especie humana.

¿Qué garantiza que finalmente los individuos accedan o acaten lo determinado por el Estado? El que esa sesión de su propio poder termine siendo útil y convenga al orden público, así como a un criterio de reciprocidad, en donde uno cede porque sabe que los demás van a ceder y en donde el Estado podrá ejercer toda la fuerza sobre aquellas personas que rompan esa confianza mutua de la sociedad por desacatar lo pactado entre las partes. Por ello, la existencia de la sociedad y del Estado solo se justifica como meros instrumentos que garanticen la seguridad y el orden para los individuos, y que existan los mecanismos suficientes, pero sobre todo eficaces, para castigar a quienes incumplan (Hobbes, 2003).

El pensamiento Hobbesiano, influye en el Realismo en el sentido que conceptualiza a través del método científico, el deseo de supervivencia como principal estímulo a la conducta humana, teniendo por ello dos formas de canalizarlo, una instintiva, irracional y "presocial" ${ }^{43}$ que termina fallando en el objetivo de garantizar la supervivencia del individuo -

\footnotetext{
42 Para mayores alcances revisar los escritos de John Locke, Rousseau que explican el Contrato Social como una forma de organizar la vida en sociedad, pudiendo ser considerados como precursores del Constitucionalismo, corriente del pensamiento jurídico.

${ }^{43}$ Se podría considerar que incluso para Hobbes, el ser humano no es un ser social por naturaleza, sino que por fines prácticos, se "adapta" a la sociedad en aras de garantizar su supervivencia, ya que como señala (Sabine, 1994) "La sociedad es meramente un cuerpo "artificial", un nombre colectivo que describe el hecho de que los
} 
puesto que al reconocerse al ser humano como un ser egoísta, deseoso de mantener lo que posee y ampliarlo, esto lleva a una constante lucha, muchas veces violenta, con sus semejantes-, justamente por ello, es que a través de la razón humana, el ser humano pacta con otros para que cada individuo ceda sus parcelas de poder en aras de que este "Leviatán" sea quien monopolice el poder de la fuerza, garantizando el orden, la seguridad y la subsistencia de las personas.

Por ello, el principal aporte de la obra de Hobbes a la política internacional, es justamente que las conclusiones llegadas mediante el método científico, de las motivaciones y respuestas conductuales por parte de los individuos, coinciden de igual manera a las motivaciones y conductas de respuesta, de las colectividades política administrativas vistas a lo largo de la historia en el escenario internacional. No obstante, con el proceso integrador germánico, es que la idea del Leviatán, logra por primera vez en la historia materializarse en el escenario internacional, siendo los Estados germánicos, el equivalente a los individuos, quienes finalmente cedan este poder -soberanía- a un "Leviatán” (Confederación Germánica y posteriormente el II Reich), mediante un "Pacto social" -tratado fundacional- cuyo proceso es conducido mediante el DI, que generó los mecanismos legales para que este proyecto integrador llegase a buen puerto.

Asimismo, dentro de la esfera de política local, el pensamiento Hobbesiano se implementó a través del absolutismo en un primer momento, con el devenir de los tiempos, se observa que este sigue vigente, ya no por el modelo absolutista, casi inexistente en el mundo occidental contemporáneo, sino través de la noción de cesión del poder, materializada en el contrato social o constitucionalismo, por ello es que existe una mayor similitud entre el DI y el Derecho Constitucional, el cual se desarrollará más adelante.

Finalmente, es oportuno acotar, que existen muchos más autores que interpretan y plantean posturas o corrientes dentro del realismo; sin embargo se ha considerado pertinente para la presente investigación centrarse en una idea de un realismo más clásico en donde se entiende como principal actor al Estado, en donde se conciben las relaciones internacionales como un espacio de conflicto entre los actores - no necesariamente a la escalada bélica, pero sí la disputa por control, recursos, obtener mayor protagonismo o hegemonía,- y finalmente la 
centralidad del poder, es decir el deseo por concentrar y logar más poder dentro del escenario internacional (Barbe, 1987).

\subsection{La Política Internacional como creadora del Derecho de Integración}

La Política es el punto de partida del Derecho, siendo a partir de esta que se genera una relación simbiótica y necesaria entre ambos, en donde cada uno influye y transforma al otro; es decir, los procesos y desarrollos de la primera, impactan en el otro, demandando a que este último también evolucione y se adapte a los avances del primero, manteniendo la correlación entre ambos, puesto que el Derecho regula la realidad, pero también la realidad regula al Derecho, y al ser el ser humano un ser político (zoon politikoon), la realidad humana es una realidad política que influye de igual forma en el Derecho, cerrándose de esta forma el círculo constante de influencia continua entre uno y otro.

Sin embargo, si bien las teorías antes mencionadas reconocen un origen común del DI y el DIP, existiendo una relación entre estos dos Derechos, este origen no tiene como elemento común al "Tratado" -que es el objeto material por excelencia del DIP- sino las necesidades políticas.

El DIP como el DI son Derechos que nacen de necesidades políticas, específicamente en la necesidad de restablecer el equilibrio después de la guerra, mantener la paz y evitar un nuevo enfrentamiento armado entre los Estados garantizando la supervivencia de los mismos. Es decir, nacen de las necesidades de la Política Internacional.

Ya Martti Koskenniemi, en su obra "From Apology to Utopia, The Structure of Internacional Legal Argument” reconocía el origen político del DIP, (Koskenniemi, 2005).

Sin embargo, ese origen "político" del DIP que señala Koskenniemi, no es exclusivo de esta rama del Derecho, ya que al tener la política dos alcances de aplicación, uno local/estatal (dentro de un determinado espacio o territorio, en donde se estructura y materializan las relaciones de poder entre los individuos dentro de una organización social y/o políticoadministrativa que vela por sus intereses), y uno externo/internacional (en donde dichas organizaciones político-administrativas se relacionan con otras similares o equivalentes); se puede afirmar, que dentro de los Derechos, cuyos orígenes parten de la política, se 
encuentran dos vertientes, una orientada a la Política Internacional (Derecho Internacional Público y Derecho de Integración) y una a la Política Local (Derecho Constitucional), de los cuales se desprenderán otras ramas del Derecho que complementen las funciones de los antes mencionados, en aras de alcanzar una mayor efectividad que garantice los fines políticos para los cuales estos sirven.

En la presente investigación se ha señalado que las coyunturas políticas (caos, desorden, entre otras), generan las necesidades para que se tengan que crear o estructurar herramientas que puedan dar las soluciones a las coyunturas antes señaladas. Es en este punto, donde se descubre al Derecho como la herramienta de la Política, el medio, por donde esta va a poder alcanzar sus objetivos: orden, paz, bienestar, etc. ${ }^{44}$

El DIP como el DI, son Derechos que nacen de necesidades de la Política Internacional, específicamente en la necesidad de restablecer el equilibrio después de la guerra, mantener la paz y evitar un nuevo enfrentamiento armado entre los Estados. Estos Derechos tienen alcances y características distintas, que, si bien no los hace iguales, los hace estar relacionados entre sí. Hay que tener presente que el DIP tiene como objetivo garantizar la co-existencia, y en última instancia, la cooperación entre los Estados con la finalidad de garantizar la paz y regular los conflictos entre los mismos. Es decir, mantener un equilibrio de poder entre los actores internacionales dentro del escenario internacional. Sin embargo, dicho objetivo, busca conseguirlo a través de una visión idealista del escenario internacional, carente de un poder superior dotado de una capacidad coercitiva que garantice el equilibrio logrado, por lo que no hay una plena efectividad en alcanzar los objetivos que este persigue. Por otra parte, el DI nace de la convergencia de intereses entre Estados, que de forma libre y voluntaria acuerdan ceder parcelas de su soberanía, para depositarla en un OS dotado de personería jurídica distinta e independiente de estos, con la capacidad de hacer cumplir coercitivamente lo pactado en el Tratado Fundacional y en todas aquellas decisiones / legislaciones comunitarias derivadas del mismo. Por ello, posee un mayor grado de efectividad al momento de mantener y garantizar la paz, así como el orden internacional, aun cuando sus efectos solo se limiten a una porción geográfica limitada del escenario internacional.

\footnotetext{
${ }^{44}$ Es oportuno recalcar, que ya varios autores, tanto de línea idealista como realista, reconocen al Derecho como la herramienta mediante la cual la política alcanza los fines que esta persigue.
} 
Por otra parte, en lo concerniente al ámbito de alcance local/estatal de la Política, el Derecho por excelencia es el Derecho Constitucional, el cual tiene su origen y antecedente directo en el Pacto Social, el cual constituye el medio jurídico fundamental a través del cual las sociedades que habitan un determinado territorio pueden alcanzar una organización políticoadministrativa que en un primer lugar, garantice la supervivencia y seguridad de los individuos que la componen; en segundo lugar, garantice el bienestar y desarrollo en las múltiples esferas de la vida cotidiana de estos individuos -económica, académica, científica, entre otras-; para que finalmente, al alcanzar el bienestar antes mencionado y por ende un mayor número de individuos que la componen, se estructure una organización políticoadministrativa, que permita a esas sociedades poder tener proyección en el escenario internacional, para que de esa forma puedan correlacionarse y seguir proyectando las propias características humanas (el deseo de mayor poder, de asegurar sus bienes y buscar el aumento de los mismos, entre otros), en espacios geográficos y demográficos, mucho más amplios en los que primigeniamente estos se desarrollaban. Este proceso jamás se hubiera alcanzado en los elementos antes descritos, así como la capacidad de proyección en el escenario internacional, de no ser por el Contrato Social inicialmente y luego con el Derecho Constitucional.

El proceso mediante el cual el Derecho Constitucional alcanza los fines antes descritos, resulta ser muy similar - por no decir equivalente- al DI, para demostrar dicha equivalencia, se desarrollará el proceso político-constitucional contrastándolo con el proceso político integrador en el siguiente acápite.

\subsubsection{El Organismo Supranacional como "El Súper Leviatán”, el Tratado Fundacional como "Pacto Social Internacional".}

Como bien se ha mencionado en el anterior punto, el Derecho Constitucional, nace de las necesidades derivadas de la de aplicación local/estatal de la política, es decir de la Política Local; sin embargo, dichas necesidades son tan antiguas -incluso más que las necesidades de la Política Internacional- como la historia misma del ser humano.

La evolución y el desarrollo social del ser humano siempre han ido acompañadas de la 
violencia y del enfrentamiento entre los individuos (y también de los colectivos de personas en sus diversas modalidades: familias, tribus, ciudades, naciones, entre otras). No obstante, en la medida que los números de individuos aumentaban dentro de estos grupos sociales, la forma de organizarlos y mantener la cohesión social, generó la necesidad de diseñar una estructura de poder capaz de ordenarlos (llámense Polis, ciudades, naciones, entre otras) y garantizar la supervivencia, así como el bienestar de los individuos.

Todas esas organizaciones político-administrativas no hubieran tenido éxito que en sus tiempos alcanzaron, de no ser por un componente central: el Pacto Social, antecedente directo a la noción de Derecho Constitucional.

¿Por qué se sostiene que es el antecedente directo al Derecho Constitucional? Porque si bien el "Pacto Social" se habla recién con Hobbes, con Locke, Rousseau entre otros, ello no significa que no haya existido desde antes. Asimismo, al ser el Pacto Social el acuerdo emanado del Poder Constituyente entre todos los individuos de una sociedad, el cual determina los derechos y obligaciones de todos estos, así como la estructuración de la organización político-administrativa y finalmente la relación entre esta y los individuos; la materialización de dicho pacto, la "positivización” del mismo, es la Constitución, el objeto de estudio por excelencia del Derecho Constitucional.

Lo que finalmente da como resultado la existencia de un "Leviatán" -al cual, si bien en un primer momento se le asociaba al monarca o al modelo de Estado Absolutista, - para fines prácticos y reales, dicho Leviatán termina siendo el Estado, dado que este es el receptor de las parcelas de poder que todo individuo cede a través del pacto social.

Por ello, es que hará un breve desarrollo sobre la Teoría del Estado, tomando como referentes a uno de los más grandes juristas alemanes y máximo representante de la Teoría General del Derecho y padre del Positivismo Jurídico, Hans Kelsen (1881-1973) y por otra parte Rudolf Smend (1882-1975), jurista alemán poco conocido en Hispanoamérica - pero no por ello no menos brillante -, con quien estableció un debate sobre la teoría del Estado, tomando una postura antagónica con Kelsen y siendo refutado por este último en su obra "El estado como integración. Una controversia de principio" 45.

45 La referida obra se dirige contra las tesis de Rudolf Smend en su obra Verfassung und Versassungsrecht.
(Kelsen, El Estado como integración. Una controversia como principio, 2009, pág. IX), refutando los 50 
Para poder entender en qué consistió dicho debate, así como la aparente postura antagónica de Smend respecto a Kelsen y como estas finalmente terminan aportando a la hipótesis planteada en la presente investigación, sobre que el DI nace de las necesidades propias de la política internacional, pero por sus propias características se asemeja más al Derecho Constitucional que al DIP, es pertinente hacer una breve reseña sobre cada autor y sus planteamientos.

\section{a) Kelsen: Teoría General del Derecho y su visión del Estado.}

Para Kelsen, el Estado es la máxima expresión del Derecho, entendido que no puede existir Estado sin Derecho (Kelsen, 1995).

Asimismo, acorde con Juan Antonio García Amado:

Para Kelsen el Estado carece de toda realidad sustancial y previa al derecho, el Estado es "un ordenamiento jurídico relativamente centralizado". Existirían derechos preestatales, ordenamientos jurídicos carentes del grado de centralización institucional, que caracteriza los Estado, y también en nuestra época, el ordenamiento jurídico internacional ${ }^{46}$ sería un ejemplo de derecho sin Estado. Lo que Kelsen rechaza es que exista una realidad del Estado previa o distinta de la de un ordenamiento jurídico. Allí donde no hay ordenamiento jurídico no hay Estado en ninguna forma. El Estado carece de toda realidad que no sea la de un derecho que vale y está vigente en un determinado territorio (Kelsen, 2009, p. X).

Este atribuye tres elementos al Estado: pueblo, territorio y poder, los cuales se explicarán a continuación.

El pueblo, sin lugar a dudas es el elemento central y quizás hasta el más importante que compone al Estado. Es el espíritu del Estado mismo, dado que, siguiendo la línea de la teoría del Leviatán de Hobbes y del Pacto Social, los individuos ceden sus parcelas de poder a una entelequia jurídica, con personalidad distinta a los individuos que lo componen, es decir, el pueblo otorga su poder al Estado. No se podría hablar de Estado, sin que exista el "Poder Constituyente" que emana del pueblo y que finalmente -valga la redundancia- constituye al

planteamientos y la visión que este tiene sobre la teoría del Estado según lo señalado por Juan Antonio García Amado, en el estudio preliminar a dicha obra.

${ }^{46}$ Entiéndase DIP. 
Estado mismo. Por otra parte, se reitera lo afirmado en que este elemento, es el elemento "espiritual" del Estado, porque las características propias que este tenga, son el reflejo del pueblo que lo conforma, ya sea por el o los idiomas, la historia, la cosmovisión y la moral reflejada en su ordenamiento jurídico. Estas características terminan siendo el reflejo, la proyección del "espíritu del pueblo". Por ello, es propio afirmar que el Estado es la proyección de la moral colectiva y del pueblo mismo, y que cuando el primero, no refleja las características propias del último, es que surgen las crisis y caos que rompen el balance, el equilibrio del Pacto Social.

El territorio, el cual es el espacio geofísico, sobre el cual el pueblo se ubica y en donde el poder del Estado termina siendo aplicado, es decir, el territorio es el límite físico del alcance del poder estatal sobre sí mismo, su pueblo, todos los individuos que se encuentren en este y los recursos dentro de este espacio geofísico. Asimismo, dentro del escenario internacional, es la materialización del Estado, en donde alcanza una interrelación física con otros, gracias a sus límites territoriales sobre los cuales ejercerá su propio poder frente a terceros, es decir donde el Estado ejerce su soberanía.

Y finalmente el poder, pero no entendido como un concepto etéreo o abstracto, el poder entendido como una organización, una estructuración sobre la cual el Estado mismo se manifiesta sobre su población y territorio, pero también sobre el escenario internacional.

Desde una visión más contemporánea y moderna del Estado, este elemento que reconoce Kelsen, encuentra su máxima expresión en el Estado de Derecho, en el cual existe una partición del poder estatal, materializado -históricamente al menos-, en un poder ejecutivo, encargado de ejercer el Ius Puniendi, la seguridad del pueblo y de sus individuos, así como la seguridad del Estado mismo, tanto frente a amenazas internas, como las externas; un poder legislativo, encargado de normar sobre la base de una Constitución -Pacto Social- y asimismo logar el desarrollo de la misma, regulando no solo al pueblo, sino al territorio que compone al Estado y finalmente un poder judicial, encargado de resolver las controversias entre los particulares, así como los conflictos que pudieran desarrollarse entre los individuos y el Estado mismo en el territorio que lo compone, sobre la base y límites de la constitución y de la legislación. 
Como se observa, existe una estrecha correlación entre los 3 elementos del Estado: pueblo que da poder, pero con las características propias del mismo, el cual se materializa en una Constitución-Pacto Social-, la cual determina las características y formas del Estado mismo, ejerciéndose en un territorio, pero a su vez dando forma al poder del Estado en conformidad con la visión e intereses del pueblo mismo, pero que a su vez recaerá sobre este, en aras de garantizar su propia seguridad y satisfacer sus intereses.

Finalmente, Kelsen no duda de los componentes ético morales que el Pacto Social pueda tener (contrariamente a lo que sus detractores sostienen), pero es a través de este pacto, materializado, "positivizado" en la Constitución, la cual es "La ley de Leyes", sobre la cual el Estado nace, y es gracias a la norma misma, que este existe y se mantiene en el tiempo (Kelsen, 2009, pp. 44-45). Por ello para Kelsen, este entiende al Estado como un ordenamiento jurídico bajo el que viven hombres, y de ahí que enfoque todos los problemas de la teoría del Estado como problemas de la validez y producción de un ordenamiento, de un sistema normativo (Kelsen, 2009, p. 45).

Con lo antes expuesto, se demuestra las necesidades políticas como creadoras del Derecho, en específico a las necesidades de la política de alcance local, ya que esta persigue establecer un orden que garantice la seguridad y el bienestar de los individuos en una sociedad, siendo el Derecho Constitucional la herramienta jurídica por la cual la política local alcanza el objetivo que persigue.

\section{b) Smend: La integración como proceso creador del Estado.}

Para entender la Teoría del Estado de Smend, es necesario entender y contextualizar su pensamiento filosófico, el cual nos permitirá entender los lineamientos, así como la metodología sobre la cual este autor desarrolla su visión e interpretación del Estado.

Smend se encuentra dentro de la escuela Hegeliana, cuya obra "Fenomenología del Espíritu" expone los lineamientos académicos sobre la cual se compone en su análisis y método para entender la realidad y el conocimiento. A modo de síntesis, el término Fenomenología, proviene del griego "Phainomenon" que significa "que resplandece", que "se manifiesta"; es decir, la idea de esta obra es el "cómo se va a manifestar el espíritu", siendo el espíritu, donciencia (Hegel, 2016). En última instancia, el sistema Hegeliano, lo que persigue es 
estudiar la manera cómo se manifiesta y desarrolla las diferentes etapas de la conciencia, ${ }^{47}$ estableciendo cuáles son los tipos y formas a través de la cual la conciencia evoluciona. ${ }^{48}$

Para (Hegel, 2016), todo lo real, y por lo tanto la conciencia que determina el valor de lo real, no es estático, estando en un continuo desarrollo y evolución. Ya que no existe un único estado de conciencia, puesto que hay diferentes formas en las cuales esta se manifiesta y, en la medida en que esta se manifiesta, se auto conoce y desarrolla (Hegel, 2016). Dicho proceso de auto conocimiento y desarrollo lo denomina dialéctica.

¿Por qué es importante resaltar solo este elemento de una obra tan compleja como la Fenomenología del Espíritu de Hegel? Porque esa idea sintetiza la metodología de análisis a través de la cual Smend conceptualiza la visión espiritual del Estado, con la salvedad que, para el constitucionalista, el espíritu no tiene la connotación de "conciencia” como sí lo establece Hegel, para él, el espíritu serán todas esas características propias de las expresiones humanas (patriotismo, moral, sentido de pertenencia, entre otras).

\footnotetext{
${ }^{47}$ Hegel sostiene que hay 3 etapas de conciencia:
}

La primera, denominada sensible, que a través del cual el hombre mediante los sentidos toma conciencia del mundo exterior que lo rodea en la realidad, siendo un mundo en constante cambio. Sin embargo, en esta etapa, se carece de conciencia de sí mismo - por eso la define como la etapa más primitiva de conciencia del ser humano.

La segunda, denominada autoconciencia, el ser humano descubre que los conceptos que atribuye a las experiencias sensoriales del mundo exterior, no son intrínsecos a los objetos, que existe algo más que finalmente determina u otorga un concepto a ese objeto, y ese algo más es para Hegel, la conciencia misma; siendo este punto cuando la conciencia toma conciencia de sí misma y se auto descubre o auto conoce.

La tercera, denominada la del saber absoluto, Hegel sostiene que existe una separación entre el mundo exterior y la conciencia misma, dado que todo lo que existe en la realidad y el mundo exterior, surge finalmente de la conciencia misma, puesto que lo cambiante del mundo de los objetos, surge de la inmutabilidad de la conciencia, existiendo una dependencia del mundo exterior con el mundo interior. Para Hegel, cuando esta separación de lo exterior y lo interior sea superada, el ser humano experimentará que este en sí mismo es el "espíritu absoluto" y que todo el universo es expresión de su propia conciencia (Hegel, 2016).

48 No es objeto de la presente investigación ahondar sobre la obra de Hegel - dado que esto nos desviaría del objetivo que se busca demostrar -, para un mayor entendimiento y detalle de la misma revisar su obra "Fenomenología del Espíritu", publicada en 1807. 


\section{Haciendo referencia a Juan Antonio García Amado,}

Smend pretende elaborar una doctrina de la Constitución en pugna con las tesis de la teoría jurídica y constitucional del positivismo y particularmente contra la doctrina de Kelsen y su Escuela, la Escuela de Viena que tilda de formalista. Rechaza Smend una doctrina constitucional que vea en la Constitución meramente como norma jurídica, con el argumento de que la Constitución de un Estado es plasmación o cristalización de una realidad objetiva, la realidad del Estado ${ }^{49}$ (Kelsen, 2009, p. X).

Dicha doctrina que plantea elaborar, considera que las realidades estatales son pre jurídicas y que se constituyen sobre un sentimiento de comunidad presente entre individuos de un colectivo. A dicho sentimiento lo denomina "integración”. Sin ella no hay Estado propiamente dicho y la Constitución es el resultado y cauce de esa integración determinante de la comunidad estatal. Dicha "integración" es un sentimiento común aglutinante de sentimientos y valores (Kelsen, 2009, pp. XI, XIV).

Según lo señalado por (García Roca, 1988, p. 271), Smend, considera que la Constitución es

(...) la ordenación jurídica de la integración política de los ciudadanos en el Estado y, por ello, también el fruto de la eficacia integradora de sus normas, muy especialmente de sus valores y derechos fundamentales. La singularización de las normas constitucionales como normas de cultura, que recaban fundamentaciones extranormativas.

Por ello, es que conforme al análisis esbozado por (Lucas Verdú, 1987) este considera que para Smend, las declaraciones, así como los preámbulos de las Constituciones son los elementos que configuran la esencia y realidad del Estado, de tal manera que todo aquello que se añada a ellos son una serie de normas que contribuyen a su realización.

Tal como se señaló con Kelsen, este considera al Estado como una entelequia jurídica, con personalidad jurídica propia independiente de los individuos que lo componen y con un fin en sí mismo (Kelsen, 1995). Sin embargo, Smend rechaza esa concepción del Estado y en

\footnotetext{
${ }^{49}$ Dicha realidad objetiva para Smend, es lo que él denomina "integración", integración que se constituye sobre elementos que él denomina "mónadas espirituales" (Smend, 1985, pág. 57).
} 
su búsqueda por definir qué es el Estado, acude a la Ciencia del Espíritu ${ }^{50}$, la cual demostraba que individuo y comunidad no son realidades autónomas, sino interdependientes y recíprocamente constitutivas, donde existe un sistema de influencias mutuas, un flujo circular entre lo individual y lo supraindividual (comunidad), un círculo cerrado ${ }^{51}$ donde existe una interrelación esencial entre la mayoría de los miembros del mismo (Kelsen, 2009, pp. XII y XIII; Smend, 1985, p. 57).

Por lo antes señalado, es que Smend sostiene que el Estado solo existe a causa de, y en la medida en que el individuo se halle, inmerso en un proceso de integración con otros individuos desarrollado a partir de eso que denomina "espíritu". Es decir, la convergencia de las características tales como los idiomas, la historia, la cosmovisión y la moral, las que finalmente constituyen -según lo desarrollado previamente en la Teoría del Estado de Kelsen- el "espíritu del pueblo".

Esa eficacia integradora depende de dos momentos distintos:

(...) que su principio constitutivo (en este caso el de la mayoría de individuos) tenga en sí fuerza integradora -a mayor convergencia de características, mayor fuerza-, y por otro de que esa fuerza integre realmente a toda la comunidad política.

La eficacia integrada se halla condicionada por la existencia de una comunidad de valores que no es cuestionada por la lucha política porque se mantiene a salvo de ella, comunidad de valores que dota de pautas normativas a la lucha y le da su sentido como función integradora de la vida del grupo (Smend, 1985, p. 87).

$\mathrm{Y}$ en el caso de los grupos que no comparten o se hallen vinculados con ese conjunto de valores, se desligarán rápidamente de las reglas del juego -del Pacto Social- y por tanto la eficacia de la integración, se verá obstruida y finalmente destruida (Smend, 1985, p. 87).

No obstante, no existe en última instancia ningún modo de integración formal sin una comunidad material de valores, del mismo modo que no es posible la integración a través

\footnotetext{
${ }^{50}$ Para entender mejor qué es la ciencia del espíritu, revisar Individuum und Gemeinschaft de Theodor Litt.

${ }^{51}$ Se observa acá la clara influencia del pensamiento Hegeliano en lo que concierne a la interdependencia del mundo exterior (comunidad) y mundo interior (individuo) vinculados a través de la dialéctica.
} 
valores sustantivos si no existen formas funcionales (Smend, 1985, p. 92). Con esa aseveración Smend reconoce la importancia de la positivización de cosmovisión ético-moral de la comunidad, así como la estructuración del poder (Lucas Verdú, 1987; García Roca, 1988) (entendido este último como el tercer elemento de la Teoría del Estado de Kelsen, desarrollado previamente en la presente investigación). Y ello surge de forma análoga a lo que sucede en la vida psicofísica del hombre, en donde la necesidad de un poder de dominación fuerte -capaz de imponerse en el interior y en el exterior del colectivo, garantizando la seguridad del mismo- sea finalmente la clave para la naturaleza del Estado.

El Estado ha de ejercer su señorío en su propio territorio ${ }^{52}$; la pasión de poder del hombre ha de ser satisfecha a través de la participación en esta comunidad que detenta el poder; sólo así se realizará la parte correspondiente del entramado significativo y cultural: por todas estas razones, el Estado sólo es real, si, en el interior, gobierna a través del Derecho y gracias las fuerzas impositiva de su poder; y si es capaz de garantizar efectivamente la defensa hacia afuera (Smend, 1985, p. 94).

Esto es lo que Smend denomina integración material, la cual finalmente logra satisfacer esa necesidad de poder de los individuos, no solo en el Ius Puniendi, sino en lograr el deseo y la participación de la comunidad dentro del Estado ${ }^{53}$-sea dentro de los múltiples niveles de la burocracia pública o a través de las fuerzas armadas- y en el cuidado del mismo en el día a día, es decir, lograr un vida cívica dentro y fuera de las esferas del Estado mismo.

Finalmente, la diferencia entre la teoría del Estado de la Teoría de Kelsen y la de Smend, radica en que este último ve al Estado como una pluralidad de hombres que viven bajo un poder jurídicamente ordenado (Kelsen, 2009, p. 45), es decir, este pone como elemento constitutivo del Estado, los componentes "espirituales" de la comunidad, considerando a la Constitución como una consecuencia, un resultado, de dichos componentes; mientras que el primero, si bien también reconoce dichos componentes espirituales como fuentes de inspiración de la norma, para este, lo que finalmente integra son los componentes jurídicos,

\footnotetext{
${ }^{52}$ Como se aprecia, Smend no discute del todo los planteamientos de la Escuela Vienesa y de Kelsen, sino que discrepa en la interpretación y en el orden de importancia que ellos realizan sobre los elementos del Estado.

${ }^{53}$ Este vendría a ser el segundo momento a través del cual se alcanza la eficacia integradora, la primera es la convergencia de valores dentro de una comunidad.
} 
la Constitución, la cual ordena y estructura al Estado mismo - ya que Kelsen entiende al Estado como un ordenamiento jurídico bajo el que viven hombres, y de ahí que enfoque todos los problemas de la teoría del Estado como problemas de la validez y producción de un ordenamiento, de un sistema normativo (Kelsen, 2009, p. 45).

De este modo, es que dichos autores, no son tan antagónicos entre sí, dado que Smend reconoce mucho de los planteamientos que la Escuela de Viena, y de igual forma Kelsen con este, pero difieren en la forma en la que valoran e interpretan los elementos constitutivos del Estado: para Smend es el "espíritu" de la comunidad lo que integra y finalmente constituye al Estado -la Constitución como la "positivización" de ese espíritu-, mientras que para Kelsen, el Estado es la máxima expresión del Derecho, entendido que no puede existir Estado sin Derecho (Kelsen, 1995).

Como ya se ha establecido a lo largo de la presente investigación, el deseo de supervivencia y bienestar son los principales motores que impulsaron la necesidad de establecer un pacto social entre los individuos de una sociedad, el cual, con el devenir de los tiempos, dio como resultado las primeras organizaciones político-administrativas de la humanidad.

Ese Pacto Social, emana de todos los individuos que componen el pueblo, con las características propias que este posea, es decir, el referido pacto, se estructura bajo la cosmovisión con que este colectivo de personas entienden la realidad y con la finalidad de satisfacer las necesidades naturales antes descritas: supervivencia y bienestar; por ello, las organizaciones político-administrativas (Estado para fines más modernos o contemporáneos), terminan siendo una proyección de la colectividad misma dentro del escenario internacional, no solo en su cosmovisión de la realidad sino en sus necesidades mismas. Por ello es que dichas organizaciones político-administrativas, poseen características propias de la naturaleza humana -dado que su origen es naturalmente humano-, moviéndose dentro del escenario internacional bajo la premisa de buscar su supervivencia y garantizar su bienestar.

Al dejar establecido dos premisas fundamentales tales como: la necesidad de garantizar la supervivencia y bienestar de los individuos lleva a que estos finalmente establezcan un Pacto 
Social, el cual se desarrolla y "positiviza" en la Constitución, siendo este el medio jurídico a través del cual se logra satisfacer dichas necesidad, y que finalmente las organizaciones político-administrativas, al ser una proyección de la colectividad humana que la constituyó, terminan interactuando en el escenario internacional motivados por satisfacer y garantizar su propia supervivencia y bienestar, las cuales en última instancia, terminan satisfaciendo las mismas necesidades de los individuos que los constituyeron.

Por otro lado (De Vega, 1998, p. 28) expone una visión diferenciada -la cual no compartimos, pero resulta interesante a tener en consideración- sobre pacto social y constitución:

Debe reconocerse en primer lugar $(\ldots)$ cuáles son los derechos naturales de todos y proclamarlos (...) Para seguir el orden natural de la organización social hay que proceder, antes de toda ley constitucional, a la redacción de un pacto social. Este acto debe ser intermedio entre la declaración de derechos, que le sirve de base, y la Constitución, a la que sirve de barrera y regulador. Si el pacto social difiere de una simple declaración de derechos, difiere más aún de un acto constitucional. Hacer un pacto social es redactar el instrumento por el que ciertas personas consienten formar una asociación con tales o cuales condiciones previas. Hacer una Constitución, por el contrario, es únicamente determinar la forma de gobierno (...) En un caso se crea la sociedad, en el otro se organiza ${ }^{54}$

No obstante, a lo largo de la historia dichas organizaciones político-administrativas, en su afán por satisfacer las motivaciones antes mencionadas, y acorde con la visión del Realismo Político -antes descrito- en las relaciones internacionales, se configuraron una serie de enfrentamiento y guerras a lo largo de la historia; no siendo hasta con el primer proceso de unificación germánico, ${ }^{55}$ que se desarrolló una nueva herramienta jurídica capaz, no solo de

\footnotetext{
${ }^{54}$ Se discrepa de esta visión puesto que el pacto social no es solamente una mera declaración de derechos entre los individuos, sino también los deberes entre todos y cada uno de las partes que lo suscriben y, como todo buen pacto, para que este sea efectivo, debe contar con los mecanismos de control y los elementos coercitivos capaces de sancionar a todos aquellos elementos disruptivos que atenten contra lo pactado; por ello, es que se sostiene que la positivización del pacto social es la Constitución misma, dado que en el pacto social no solo se funda la sociedad, sino se estructura la organización político-administrativa, que a la par con su desarrollo y evolución, da paso a la Constitución y al Estado como se entiende en nuestros días.

${ }^{55}$ Al segundo se le conoce como "Reunificación Alemana"; es decir con la re-integración de la Alemana Federal y la República Democrática Alemana a fines de los ochentas.
} 
satisfacer la seguridad y bienestar de $\operatorname{los}$ Estados $^{56}$, sino de reducir la conflictividad entre los mismos y mantener la paz: El Derecho de Integración.

El proceso jurídico de integración a través del DI, que deviene en la constitución de un Organismo Supranacional, resulta equivalente al proceso constitucional de creación de Estados; por ello es que se sostiene que el OS es el "Súper Leviatán" y el Tratado Fundacional un "Pacto Social Internacional", por las razones que se explicarán a continuación.

En el proceso de edificar un Estado, el elemento material sobre el cual este se construye es la Constitución, la cual es la positivización del Pacto Social; este proceso, tiene su origen en el poder constituyente, el cual emana del pueblo, pero que, a su vez, emana de todo individuo, ya que este último renuncia al ejercicio de su propio poder natural, en las formas y alcances, en que los demás individuos acuerden y pacten entre ellos. De esta forma, la renuncia al ejercicio absoluto del propio poder que todo individuo posee, se da por cederlo al Estado, el cual será el receptor de todo el poder popular, siendo este el único que regule las situaciones de conflicto entre los individuos (garantice la seguridad de los mismos) y que genere los espacios u oportunidades para garantizar el bienestar de estos, conforme a lo que se haya pactado (o establecido en la Constitución).

Por otra parte, en el proceso de crear un OS el objeto material sobre el cual este se constituye termina siendo el Tratado Fundacional; este proceso, tiene su origen en el poder de los Estados, es decir la soberanía estatal ${ }^{57}$. Los Estados, por considerar conveniente a sus intereses así como los fines que estos persiguen, ceden parcelas de su soberanía junto con otros, en los ámbitos, alcances y formas que estos previamente hayan acordado, constituyéndose de esta forma, la supranacionalidad establecida previamente por Sobrino Heredia $^{58}$, así como un nuevo sujeto con personalidad jurídica internacional, cuyo origen no

\footnotetext{
${ }^{56} \mathrm{Si}$ bien a lo largo del presente punto se ha hecho referencia a organizaciones político-administrativas, es pertinente hacer mención al término Estado, dado que para el contexto en que se inicia el proceso de integración germánico mediante el Derecho de Integración, es que la noción de Estado ya existe y se emplea para referirnos, de manera más específica, a dichas organizaciones.

57 Si bien ya se ha desarrollado los conceptos de este término, se puede considerar para el presente caso, que la soberanía termina siendo la suma de todos los poderes de los individuos que cedieron su poder en el pacto social a favor del Estado.

${ }^{58}$ Revisar páginas 37 a 39 de la presente investigación.
} 
radica directamente del poder constituyente de los individuos, sino de la soberanía estatal.

En efecto $(\operatorname{los} \mathrm{OS})^{59}$, van a disfrutar de personalidad jurídica internacional, pero a diferencia de los Estados, sujetos originarios y soberanos, que poseen una personalidad plena y general, la personalidad de las Organizaciones va a estar afectada por el principio de la especialidad que inspira todo su régimen jurídico; es decir, va a estar limitada a los objetivos y funciones que les fueron confiados, tal y como aparecen enunciados o pueden deducirse de sus tratados constitutivos y han sido desarrollados en la práctica. Se trata, en suma, de una personalidad funcional, que se nutre de las competencias que les atribuyen los Estados. Los ámbitos, atribuidos pueden ser más o menos numerosos e importantes, sin embargo, nunca se encuentra como en el Estado, frente a un campo de acción teóricamente ilimitado (Sobrino Heredia, 2001, p. 8).

De esta forma, la renuncia al ejercicio absoluto de la soberanía que todo Estado posee, se da por ceder dichas parcelas al OS, el cual será el receptor de ese poder Estatal, y podrá ejercerlo exclusivamente en los ámbitos, alcances y formas que se haya pactado en el Tratado Constitutivo entre todas las partes; empoderando al OS para que pueda regular e intervenir sobre los Estados que lo componen en todas aquellas materias previamente establecidas, garantizando de esa forma la seguridad alcanzar los objetivos por los cuales este OS fue constituido.

El ordenamiento europeo ha surgido de una limitación de las soberanías de los Estados miembros, que puede tener origen en una cesión de soberanía o bien en una delegación realizada por los Estados miembros hacia las instituciones comunitarias y a través de ellas a la Comunidad en su conjunto (Falcón, 2012, p. $65)$.

Por lo antes descrito, se observa que el Tratado Fundacional, o "Tratado Constituyente" termina siendo la Constitución del OS, tal como lo señala (Ortiz Ahlf, 2003, p. 14), los jueces del TJCE llegaron a la conclusión en su Opinión de 1991 vinculada con el Espacio Económico Europeo, de que el Tratado Constituyente de la Comunidad Europea equivale a una Constitución formal de la Comunidad Europea.

No obstante, igual surge la interrogante sobre si el OS poseen verdaderamente una

${ }^{59}$ Incorporación de OS para un mejor entendimiento a la referida cita. 
“Constitución” propia semejante a los Estados o no. Frente a esta interrogante, existen dos posiciones -antagónicas- una de otra.

Acorde con (Robles Morchón, 1996, p. 35) establece que,

Si se emplea esa palabra en un sentido meramente jurídico, neutro, desconectada de exigencias de tipo político que han de encarnar en determinadas formas institucionales, puede afirmarse que la Comunidad ${ }^{60}$ tiene su propia constitución. En este amplio sentido, la constitución es el conjunto de normas que regula la estructura orgánica de un ente autónomo jurídicamente, y por consiguiente capaz de emitir sus propias normas. Los Tratados constitutivos (con sus modificaciones y complementos, a los que nos referiremos en el capítulo correspondiente) establecen los órganos institucionales de la Comunidad con el carácter de órganos independientes de cualquier otro poder y capaces de producir su propio ordenamiento. Es más, los Tratados no sólo crean la estructura orgánica de la Comunidad, sino que también determinan los principios básicos de actuación política en los diversos sectores de la acción comunitaria (las llamadas políticas comunitarias), por lo cual junto al aspecto orgánico se incorporan los principios. $\mathrm{Si}$ se relativizamos el concepto de constitución hasta exigirle tan sólo el cumplimiento del requisito de que establezca el núcleo institucional básico para que un ente jurídico funcione con carácter autónomo, parece evidente que la Comunidad posee su propia constitución.

Pero, por otro lado, el autor también pone en evidencia la otra postura la cual señala lo siguiente:

$\mathrm{Si}$, por el contrario, se parte del concepto usual de constitución, caracterizado por que exige de ella que, además de la determinación del aparato institucional superior de una entidad jurídica con autonomía propia, transcriban sus normas los valores políticos fundamentales de la democracia liberal (separación de poderes en su sentido clásico y respeto a los derechos fundamentales), entonces la respuesta puede ser que la Comunidad carece de constitución propia. Las exigencias mencionadas son las que prescribe el famoso artículo 16 de la Declaración francesa de los Derechos del Hombre y del Ciudadano de 26 de agosto de 1789, que dice: $<<$ Toda sociedad en la cual la garantía de los derechos no está asegurada ni la

${ }^{60} \mathrm{El}$ concepto que emplea el autor, para fines de la presente investigación hace referencia al OS. 
separación de poderes establecida, carece de constitución>>. La lectura de los Tratados constitutivos demuestra que en la Comunidad ni se produce la separación de poderes al modo en que se entiende tal separación en los Estados de democracia parlamentaria, ni tampoco se garantizan los derechos.

En la Comunidad ${ }^{61}$ hay, ciertamente, separación de poderes, los que corresponden a sus instituciones básicas (Parlamento Europeo, Comisión, Consejo, Tribunal de Justicia y Tribunal de Cuentas, según el art. 4 TCE); estas instituciones deben actuar $<<$ dentro de los límites de las competencias atribuidas $>>$ por los Tratados, lo que implica una delimitación de las competencias y una correlativa separación de poderes. Ahora bien, esta separación de poderes no se corresponde con la separación de poderes que exige el mencionado artículo de la Declaración francesa, que como es notorio está pensando en la distribución del poder en los tres clásicos poderes del Estado (legislativo, ejecutivo y judicial) y, además, en la primacía del Parlamento como poder legislativo que, como representante del pueblo soberano), crea las normas a las que han de someterse los otros dos poderes. Los poderes de la Comunidad no están estructurados de acuerdo con este modelo. El Parlamento Europeo no tiene, ni mucho menos, el protagonismo de los Parlamentos de los Estados democráticos, pues ni siquiera actúa por sí mismo como institución legislativa, y su función de control sobre el <<gobierno〉> de la Comunidad es muy relativa, ya que, si bien puede someter a un voto de censura a la Comisión, el Consejo (que es el órgano con mayor poder real) escapa prácticamente a su fiscalización. Además de la escasa relevancia del Parlamento Europeo (si se le compara con sus homónimos nacionales), en la conjunción de poderes que forman el Consejo (solo o en colaboración con el Parlamento) y la Comisión tiene su sede no sólo el poder ejecutivo de la Comunidad, sino también el poder legislativo. Ambas instituciones, y especialmente el Consejo (pues la Comisión actúa en general haciendo propuestas al Consejo), monopolizan ambos poderes, por lo que difícilmente se puede hablar entonces de <<separación〉> de los poderes (Robles Morchón, 1996, pp. 35-36).

Esta última postura, termina por limitar la noción de Estado, a una cosmovisión estrictamente liberal y occidental, teniendo como esencia la visión estatal derivada de la

\footnotetext{
${ }^{61}$ En el presente caso, el autor hace referencia a la Unión Europea y su estructura orgánica.
} 
Revolución Francesa; por ello, si se continuase con esta última noción, no solo el OS carecería de un equivalente a la Constitución, sino que la existencia misma de otros Estados, cuyos procesos constitutivos se fueron desarrollando bajo otros principios, cosmovisión e influencias, no serían considerados como Estados. Cayéndose en una especie de "etnocentrismo occidental" donde todo aquello que no calza bajo los cánones de "separación de poderes" o de "Estado de Derecho" no es Estado, cuando este último, en todo caso, debe ser el ideal al que todo Estado debe apuntar, mas no una condición para acreditar su existencia.

Esta última interpretación también es compartida por (Robles Morchón, 1996, p. 36):

Nosotros nos inclinamos por el punto de vista neutro o meramente jurídico, que implica una relativización y una ampliación del concepto político de constitución.

Pues pensamos que, si se adopta esta última perspectiva, la de exigir la separación de poderes y la garantía de los derechos, habría que negar a la inmensa mayoría de ser poseedores de constitución. Haciendo uso del concepto jurídico de constitución, puede afirmarse que todo Estado tiene su constitución, que estará formado por aquel documento o por aquellas tradiciones o costumbres que hayan generado en normas jurídicas la estructura orgánica fundamental del Estado. Es en este sentido como se puede afirmar que la Comunidad tiene su propia constitución.

\subsubsection{La relación entre el Derecho de Integración y el Derecho Constitucional.}

Los Estados poseen un elemento indispensable para que finalmente estos puedan ser reconocidos como tal: la soberanía, concepto político-jurídico que expresa que, la organización político-administrativa que la posee, no solo tiene la cualidad de tener autonomía normativa - es decir ser fuente creadora de su propio Derecho- sino que, no conoce superior por encima del ente soberano y regular la vida de los ciudadanos en su totalidad (Robles Morchón, 1996, p. 37).

Por ello, si la soberanía es una característica intrínseca a todos los Estados, la cual establece que no existe superior más que el ente soberano; por consiguiente, no existe ley superior que 
la Constitución del Estado mismo, por algo Kelsen la denominaba la "ley de leyes" (Kelsen, 1995). De esta forma, es que surge el principio de supremacía constitucional, el cual genera un aparente problema entre las normas internacionales de origen comunitario (normas que nacen dentro del seno de un OS) con las constituciones de los Estados que lo componen, puesto que si uno se guía de manera estricta bajo este principio, no sería posible la integración de Estados dentro del marco de un DI, dado que la norma constitucional podría contraponerse a la norma comunitaria, y en ese sentido la primera primaría, afectando al proyecto integrador; sin embargo, se ve que en la realidad estos proceso sí existen y las normas comunitarias son aplicadas en los diversos OS. Por ello habría que preguntarse, cuál prima y de qué forma es que se da esta relación entre el DI - DC y el Derecho Constitucional.

El profesor Javier Tajadura Tejada, en su ponencia presentada en el curso "Hacia una Constitución europea" de la UNED presentada en el año 2001, mencionaba lo siguiente,

Así, el dogma de la supremacía constitucional despliega sus efectos no sólo frente a las normas internas sino también frente a las normas internacionales. Y ello con independencia de la adscripción monista ${ }^{62}$ o dualista $^{63}$ tradicional del ordenamiento de que se trate (Tajadura Tejada, 2001, p. 24).

Sosteniendo que, tanto la doctrina internacionalista como constitucionalista ratifica la supremacía constitucional, pero a costa de que sea la propia norma constitucional la que ceda en el conflicto planteado con la proyectada norma internacional (Tajadura Tejada, 2001, p. 25).

Para dar un mejor alcance a lo antes citado, se tomará el caso constitucional peruano.

Acorde con la Constitución Política del Perú vigente a la fecha en la que se hizo la presente investigación ${ }^{64}$, en el acápite concerniente a Disposiciones Finales Y Transitorias, punto cuarto, se menciona lo siguiente:

\footnotetext{
${ }^{62}$ Los países de tradición monista no requieren de una norma de recepción interna para la aplicabilidad de una norma internacional (Landa Arroyo, 2017; Tajadura Tejada, 2001).

${ }^{63}$ Los países de tradición dualista, requieren del desarrollo normativo para poder integrar la normativa internacional dentro de la normativa del Estado y de esta forma poder hacerlo aplicable (Landa Arroyo, 2017; Tajadura Tejada, 2001).

${ }^{64}$ Constitución Política del Perú de 1993
} 
Cuarta. - Las normas relativas a los derechos y a las libertades que la Constitución reconoce se interpretan de conformidad con la Declaración Universal de Derechos Humanos y con los tratados y acuerdos internacionales sobre las mismas materias ratificados por el Perú.

Esto, pone de antemano una visión monista en lo que a materia de derechos humanos concierne; es decir, todo tratado que haya sido aprobado y ratificado por el Perú, es de aplicación directa para nuestro ordenamiento jurídico (SENTENCIA DEL TRIBUNAL CONSTITUCIONAL EXP. N. ${ }^{\circ}$ 1277-99-AC/TC, 1999; Landa Arroyo, 2017), ya que en el artículo $2^{\circ}$ de la referida constitución se reconocen una serie de derechos fundamentales,

Artículo $2^{\circ}$. - Toda persona tiene derecho:

1. A la vida, a su identidad, a su integridad moral, psíquica y física y a su libre desarrollo y bienestar. El concebido es sujeto de derecho en todo cuanto le favorece.

2. A la igualdad ante la ley. Nadie debe ser discriminado por motivo de origen, raza, sexo, idioma, religión, opinión, condición económica o de cualquiera otra índole.

3. A la libertad de conciencia y de religión, en forma individual o asociada. No hay persecución por razón de ideas o creencias. No hay delito de opinión. El ejercicio público de todas las confesiones es libre, siempre que no ofenda la moral ni altere el orden público.

4. A las libertades de información, opinión, expresión y difusión del pensamiento mediante la palabra oral o escrita o la imagen, por cualquier medio de comunicación social, sin previa autorización ni censura ni impedimento algunos, bajo las responsabilidades de ley. Los delitos cometidos por medio del libro, la prensa y demás medios de comunicación social se tipifican en el Código Penal y se juzgan en el fuero común. Es delito toda acción que suspende o clausura algún órgano de expresión o le impide circular libremente. Los derechos de informar y opinar comprenden los de fundar medios de comunicación.

5. A solicitar sin expresión de causa la información que requiera y a recibirla de cualquier entidad pública, en el plazo legal, con el costo que suponga el pedido. Se 
exceptúan las informaciones que afectan la intimidad personal y las que expresamente se excluyan por ley o por razones de seguridad nacional. El secreto bancario y la reserva tributaria pueden levantarse a pedido del juez, del Fiscal de la Nación, o de una comisión investigadora del Congreso con arreglo a ley y siempre que se refieran al caso investigado.

6. A que los servicios informáticos, computarizados o no, públicos o privados, no suministren informaciones que afecten la intimidad personal y familiar.

7. Al honor y a la buena reputación, a la intimidad personal y familiar, así como a la voz y a la imagen propias. Toda persona afectada por afirmaciones inexactas o agraviadas en cualquier medio de comunicación social tiene derecho a que éste se rectifique en forma gratuita, inmediata y proporcional, sin perjuicio de las responsabilidades de ley $(\ldots)^{65}$.

Y seguidamente en el artículo $3^{\circ}$ se menciona,

Artículo $3^{\circ}$. - La enumeración de los derechos establecidos en este capítulo no excluye los demás que la Constitución garantiza, ni otros de naturaleza análoga o que se fundan en la dignidad del hombre, o en los principios de soberanía del pueblo, del Estado democrático de derecho y de la forma republicana de gobierno.

Es decir, al ser los derechos fundamentales reconocidos en nuestra constitución de forma no taxativa, se desprende que todo tratado internacional que verse sobre derechos humanos ya forma parte de nuestra carta magna; de esta forma, lo mencionado por el profesor Tajadura se reafirma, ya sea porque bien el tratado, ya es parte del ordenamiento jurídico porque así lo reconoce la Constitución y por consiguiente este prima, (Disposiciones Finales y Transitorias, cuarta), o porque por su propia naturaleza, el tratado no afecta a la Constitución y su aplicación del mismo es derivada de la Carta Magna.

Sin embargo, y sin perjuicio de lo antes señalado, se encuentra también en la Constitución Política del Perú de 1993, en el capítulo II, concerniente a los tratados los siguientes artículos que merecen ser analizados.

El artículo $55^{\circ}$ establece que "los tratados celebrados por el Estado y en vigor forman parte

${ }^{65}$ Dada la enorme extensión del presente artículo, se ha recortado parte del mismo. Para fines informativos revisar la Constitución Política del Perú de 1993 para poder leerlo en su totalidad 
del derecho nacional" (visión monista); sin embargo, inmediatamente después el artículo $56^{\circ}$ menciona que,

Artículo $56^{\circ}$. - Los tratados deben ser aprobados por el Congreso antes de su ratificación por el Presidente de la República, siempre que versen sobre las siguientes materias:

1. Derechos Humanos.

2. Soberanía, dominio o integridad del Estado.

3. Defensa Nacional.

4. Obligaciones financieras del Estado.

También deben ser aprobados por el Congreso los tratados que crean, modifican o suprimen tributos; los que exigen modificación o derogación de alguna ley y los que requieren medidas legislativas para su ejecución.

Encontrando en este artículo, una visión dualista en torno a la incorporación de la norma internacional al ordenamiento jurídico, en donde se requiere una aprobación parlamentaria para que este forme parte de nuestro cuerpo jurídico a través de una Resolución Legislativa. Dicha aprobación, se fundamenta en el segundo párrafo del artículo $57^{\circ}$

Artículo $57^{\circ}$. - (...) Cuando el tratado afecte disposiciones constitucionales debe ser aprobado por el mismo procedimiento que rige la reforma de la Constitución, antes de ser ratificado por el Presidente de la República.

Por ello, las normas internacionales que versen sobre soberanía, dominio o integridad del Estado o Derechos Humanos, gozan de carácter constitucional, y si estas fueran contrarias a la constitución, su incorporación a nuestro ordenamiento jurídico será los establecidos para las reformas constitucionales - manteniéndose la hegemonía de la constitución sobre la norma internacional, dándole a esta, en último ratio, un rango de igual jerarquía-; sin embargo, el mismo artículo antes citado, hace una distinción con otro tipo de tratados que no poseen rango constitucional, sino de ley, teniendo un rango inferior a la carta magna:

Artículo $57^{\circ}$. - El Presidente de la República puede celebrar o ratificar tratados o adherir a éstos sin el requisito de la aprobación previa del Congreso en materias no contempladas en el artículo precedente. En todos esos casos, debe dar cuenta al 
Congreso (...).

De igual manera el artículo $200^{\circ}$ refuerza lo antes señalado:

Artículo $200^{\circ}$. - Son garantías constitucionales:

(...)4. La Acción de Inconstitucionalidad, que procede contra las normas que tienen rango de ley: leyes, decretos legislativos, decretos de urgencia, $\underline{\operatorname{tratados}}^{66}$, reglamentos del Congreso, normas regionales de carácter general y ordenanzas municipales que contravengan la Constitución en la forma o en el fondo (...).

Por ello, es que nuestra constitución contempla que la norma internacional, recogida en los Tratados, o derivada de los mismos, al momento de ser incorporado a nuestro ordenamiento nacional goza de una visión mixta, tal como lo señala el profesor (Landa Arroyo, 2017):

Sobre todo, si la posición constitucional de los tratados en la Constitución de 1993 no está exenta de asumir una opción mixta, con elementos monistas o dualistas, que caracteriza modernamente al derecho internacional como un derecho de integración, en base a la tutela de la persona humana. De modo que, no se postularía la derogación automática de las normas internas, en caso de conflicto con sus obligaciones en el plano internacional, sino su armonización en base a un neoiusnaturalismo integrador (...).

(...) es decir que, unas veces la norma internacional prevalecerá sobre la norma nacional, o, en otras la norma nacional prevalecerá sobre la norma internacional, en función de la norma que mejor proteja a la persona humana y a su dignidad, de conformidad con el principio democrático indubio pro homine o favor libertatis, que postula el Artículo $1^{\circ}$ de la Constitución de 1993: "La defensa de la persona humana y el respeto de su dignidad son el fin supremo de la sociedad y del Estado".

Habiendo ejemplificado la supremacía constitucional en relación a la norma internacional (y por consiguiente a la norma comunitaria), con el caso peruano, es que seguidamente se desarrollará otra postura que defiende la primacía de la norma internacional, específicamente la de la norma comunitaria, sobre el ordenamiento constitucional.

\footnotetext{
${ }^{66} \mathrm{El}$ subrayado es propio.
} 
Es importante establecer, que la doctrina constitucional que abogada por la primacía de la Constitución Estatal frente a toda norma internacional, comenzó a cuestionarse en la medida que los Estados comenzaron a integrarse bajo las esferas del DI, puesto que por las finalidades y objetivos que persiguen los procesos integradores, la primacía constitucional hubiese significado un obstáculo para consolidar dichos proyectos, surgiendo de esta forma la postura que aboga por la primacía de la norma comunitaria.

La postura que defiende la supremacía de la norma comunitaria con relación a las constituciones nacionales, tiene como máximos representantes a todos aquellos académicos especialistas en el DI-DC, así como por las sentencias emitidas por el TJC de la Unión Europea.

Acorde el TJC y la profesora Fernández Estaban, el Derecho Comunitario es una suerte de “supraconstitución” que se impone a los ordenamientos internos, y ante cuyas normas las de estos últimos han de ceder siempre (Fernandez Esteban, 1994)

Asimismo, el profesor (Tajadura Tejada, 2001) sostiene que para el Alto TribunalEuropeo, las normas del derecho comunitario, originario y derivado, se imponen siempre frente a las normas de derecho interno, cualquiera que sea su rango, es decir también frente a las de rango constitucional, ello en concordancia con la Sentencia Costa-Enel del 15 de julio de $1964^{67}$.

Para el profesor (García Herrera, 1998), La consideración del Derecho Comunitario como Ordenamiento Jurídico autónomo del de los Estados miembros no significa en la práctica otra cosa que la subordinación de éstos a aquel.

Ello, porque se entiende que al momento de que los Estados apuestan por un proyecto integrador junto a otros, requieren de dotar de mecanismos los suficientemente eficaces y fuertes - dotar de cierta coercitividad- al OS, para que los miembros de dicha comunidad mantengan una especie de "cohesión" inter-estatal, y esa dotación se fundamenta en la sesión de soberanía.

Sin embargo, es pertinente tener en cuenta que la primacía del DI-DC, frente al Derecho Constitucional Estatal tiene una limitación: los fines, formas y alcances de la integración

${ }^{67}$ Para mayores alcances, revisar la referida sentencia. 
fijados en el Tratado Fundacional y desarrollados posteriormente por el OS, dentro de los límites antes señalados. Por ello la "supranacionalidad" entendida como la suma de las soberanías estatales en los campos fijados, denota una cesión, una renuncia libre y voluntaria del Estado.

(...) aunque los Estados miembros se hayan desprendido del $<<$ ejercicio $>>$ de determinados derechos que se derivan de su soberanía, esto no puede interpretarse como si se hubieran desprendido de ésta. La soberanía de los Estados miembros queda intacta, habiendo sido objeto de renuncia tan sólo el ejercicio de algunas competencias que la configuran, pero no la soberanía en sí misma (Robles Morchón, 1996, p. 37).

Por lo antes expuesto, ¿Se puede afirmar que exista una primacía del DI frente a la Constitución?

Para poder responder a la presente interrogante, es menester definir qué se entiende por primacía. Acorde con la (Real Academia Española, 2016) es: Superioridad, ventaja o excelencia que algo tiene con respecto a otra cosa de su especie.

Por lo antes expuesto, sí se puede afirmar que existe una primacía del DI-DC sobre la constitución, pero única y exclusivamente estipulados en el tratado fundacional del OS. En todos los demás campos que no se haya fijado, la Constitución siempre primará, y en el hipotético caso existiese alguna controversia derivada de la aplicación de una norma comunitaria que repercuta en las formas, campos y alcances no fijados previamente, el Estado (que previamente por considerar beneficioso para sus intereses apostó por un proceso integrador) deberá o bien reformar su constitución para que exista una incorporación monista del DC a su propio derecho nacional, o a través de una ley especial (visión dualista) permitir su incorporación a su propio derecho, en aras de seguir apostando por el fortalecimiento e institucionalización del proceso integrador.

Si no se podría afirmar categóricamente la hegemonía de uno de estos dos derechos, ¿qué rol cumplen entre sí?

Acorde con (Robles Morchón, 1996, pp. 37-38)

(...) la relación entre Derecho Comunitario y Derecho Constitucional tiene otra 
vertiente, de no menor interés: es a través de la constitución de los Estados miembros como se articula la conexión entre el ordenamiento comunitario y el ordenamiento de cada Estado miembro. Esta conexión tiene dos momentos o aspectos diferentes: a) el momento de la incorporación del Estado a la Comunidad, que es bien el momento --ya pasado-- de la legitimación constitucional de la formación de la Comunidad por los Estados fundadores, bien cuando se produce la adhesión de nuevos Estados a la Comunidad como miembros de la misma; y b) el momento de la aplicación o ejecución del Derecho Comunitario, que en la mayoría de los casos habrá de llevarse a efecto en el territorio de los Estados miembros, que es a la vez el territorio de la Comunidad, y por los propios órganos estatales. El Derecho Constitucional de los Estados miembros tiene como cometido articular las vías de la penetración del Derecho Comunitario en los propios ordenamientos estatales, lo que conlleva la articulación de las técnicas de aplicación o ejecución del ordenamiento comunitario. En los dos momentos señalados, que implican variados y complejos problemas, el Derecho Comunitario conecta con las constituciones de los Estados miembros, por lo que sería conveniente --para poseer un panorama completo-- no sólo estudiar las soluciones de la constitución de un Estado (para nosotros, España), sino también la del resto de los Estados miembros, penetrando de esta manera en el llamado Derecho Constitucional comparado. Al tratarse, sin embargo, de una cuestión constitucional, su lugar de estudio apropiado corresponde al Derecho Constitucional, y no al Derecho Comunitario.

A modo de conclusión al presente punto, se comparte la postura de Robles Morchón, sobre que la Constitución de los Estados es la conexión que articula y facilita la aplicación del DI de formar conjunta con el ordenamiento de cada Estado miembro del OS. Es por decirlo de alguna manera el "canal" que conecta el DI, con el derecho local. Sin perjuicio de lo antes señalado, también existe una primacía de la Constitución sobre el DI y ello fundamentando en cómo, se entiende el origen de la Constitución: La positivización del Pacto Social, dado que por más que existan constituciones que puedan de forma expresa señalar la primacía de normas internacionales sobre las normas locales, o bien por la interpretación y desarrollo de la Constitución a través del control difuso o concentrado, no podría existir primacía de norma internacional alguna si no estuviese estipulado previamente en la Constitución de cada Estado. 


\section{Capítulo 3: La Integración como proceso político y económico.}

La integración es un proceso natural de la raza humana, que encuentra en esta, las formas de poder garantizar la supervivencia de sus individuos por las claras carencias fisiológicas que tienen en comparación con otras especies, por ello es que surgió el pacto social que posteriormente daría paso a la Constitución y el Derecho Constitucional.

Al haber dejado establecido que las organizaciones político-administrativas son proyecciones de las características "espirituales" de los pueblos que lo componen, estos actúan en el escenario internacional motivado por necesidades fundamentales que, de igual forma, influyen en los individuos: supervivencia y bienestar. Estas dos motivaciones naturales de todo ser vivo, que también se repiten en dichas organizaciones políticoadministrativas, propician ciertas situaciones de violencia y enfrentamiento entre otros, iguales en forma, pero diferentes en fuerza o poder, generándose que mucho de estos dejasen de existir y sean absorbidos por otras más fuertes y poderosas.

Por ello y motivados por ese deseo de supervivencia y bienestar, es que se generó, dentro de la política internacional, la necesidad de un mecanismo jurídico capaz de garantizar no solo la supervivencia y bienestar de las organizaciones político-administrativas, sino también mantener la paz después de situaciones de guerra en el escenario internacional.

En un primer momento se apostó por el Derecho Internacional Público como el medio que garantice el mantenimiento de esta paz y orden logrado después de guerras; sin embargo, como ya se ha dejado establecido en la presente investigación, la principal fortaleza o utilidad del DIP, no es ser garante de la paz, sino ser la herramienta jurídica que permite ordenar y pacificar el escenario internacional después de una guerra.

Si bien, dentro de la política internacional se había alcanzado a partir de la paz de Augsburgo y posteriormente con la paz de Westfalia, diseñar una herramienta jurídica capaz de sentar las bases para pacificar y ordenar el escenario internacional tras las guerras (DIP), todavía quedaba pendiente diseñar una herramienta jurídica capaz de mantener y garantizar la paz, lograda en un primer momento por el DIP, pero no mantenida en el tiempo por este. 


\subsection{Orígenes históricos de la Integración.}

Por ello y motivados por ese deseo de supervivencia y bienestar, es que recién en los albores del siglo XIX es que se diseña la herramienta jurídica que sí sería capaz no solo de garantizar las motivaciones de las organizaciones político-administrativas, sino de garantizar la paz, si bien no en todo el escenario internacional, sí en determinados espacios geográficos: el Derecho de Integración.

El DI es el resultado de una serie de procesos políticos vistos a lo largo de la historia de la humanidad, los cuales tuvieron como objetivo integrar a una serie de organizaciones político-administrativas, con la finalidad de garantizar la supervivencia y bienestar de éstos en el espacio-tiempo de su era. La Confederación Germánica (1815 a 1866), con el nacimiento del II Reich, es un referente a estos procesos políticos integracionistas, el cual, en el presente caso, dio como resultado el nacimiento de esta rama del Derecho.

Por ese motivo, es fundamental primero abordar el análisis histórico de dicho proceso político de integración de las diversas organizaciones político-administrativas, para que una vez efectuada la explicación, se pueda desarrollar el por qué el proceso de integración germánico, materializado en la Confederación Germánica (1815 a 1866) y con el nacimiento del II Reich, como culminación y consolidación de dicho proceso integracionista, nace esta rama del Derecho.

Antes de hablar de dichas organizaciones, es importante analizar brevemente al elemento nuclear que las compone, es decir los seres humanos. Ya que muchas de las características, así como sus propias necesidades y hasta conductas, se ven reflejadas en estas "entelequias jurídicas" a las cuales actualmente se llama Estado, pero que han existido, en menor complejidad, desde que el ser humano se hace sedentario.

Por ello, es que se sostiene que existen 4 pilares o etapas sobre las cuales se va desarrollando y sosteniendo el proceso político de integración, no solo de individuos, sino la de las organizaciones político-administrativas, las cuales en la medida que estas se vayan consolidando, darán paso a la siguiente; es decir los pilares tienen un surgimiento o desarrollo concatenado uno de otro, pero que en su conjunto sientan las bases (y por ello es 
que se les considera pilares) que sostienen el proceso jurídico mediante el cual se plasma la integración.

\subsection{Desarrollo del ser humano y pilares sociológicos de la integración}

Si se analiza a los seres humanos, desde una perspectiva biológica, con otras especies animales, son una especie débil en fuerza física, en resistencia, en velocidad, entre otros factores biológicos, lo cual llama mucho la atención que hayan sobrevivido hasta la fecha. Esta situación lleva a que se formule la siguiente pregunta ¿qué ha permitido que la raza humana sea la especie hegemónica de este planeta hasta nuestros días? Y la respuesta es evidente a todas luces, la inteligencia.

La inteligencia fue la herramienta evolutiva que permitió compensar las carencias físicas que como especie tuvieron los primeros seres humanos; fue gracias a esta que los primeros homínidos pudieron reconocer sus carencias individuales ante otras especies y entender que, en conjunto, es decir en sociedad, eran más fuerte y tenían mayores posibilidades para sobrevivir. De aquí es que se comienzan a dar las primeras sociedades primitivas, en un primer momento nómades, dedicadas a la caza y recolección, que más adelante pasarían a ser sedentarias, dedicándose a la agricultura y la domesticación de otras especies destinadas al consumo, y que siglos posteriores, formarían las primeras organizaciones políticoadministrativas (civilizaciones) que la historia conoce.

Como primeras organización político-administrativas se considera a las Polis de la antigua Grecia que, acorde con (Aguilera Barchet, 2014), la formación de las Polis es el resultado del surgimiento de nuevas actividades económicas dentro de la sociedad griega tales como la agricultura, la ganadería y el uso generalizado de la metalurgia del hierro, lo que provocó finalmente un crecimiento demográfico y la necesidad de organización. 


\subsubsection{La supervivencia como primer pilar de integración}

En los casos de pequeñas colectividades tales como las familias, bajo un concepto histórico - tradicional, el padre es el que impone el orden y regula los casos o desavenencias entre los miembros, ya que este es el que tiene la fuerza suficiente para proteger y proveer a la familia, pero a medida que la colectividad va aumentando, se torna más difícil que una sola persona pueda ejercer el poder y la fuerza para que regule e imponga el orden dentro del grupo y de esta forma provea y garantice la supervivencia del colectivo.

Cuando el hombre es trashumante y los grupos humanos son pequeños, la organización y dirección del grupo suele encomendarse al individuo que mejor puede asegurar la supervivencia de todos. Aunque suele ser auxiliado en su tarea por otro miembro del grupo - el hechicero, el brujo, el druida, el sumo sacerdoteque por ser el más sabio mantenía la tradición cultural de la tribu y actuaba como intermediario de las fuerzas sobrenaturales. Desde el punto de vista de la cohesión social, lo que mantiene unido al grupo es esencialmente el afán de sobrevivir en un medio considerablemente hostil y difícil, y en torno a esa función se organizaba la vida (...) (Aguilera Barchet, 2014, p. 36).

En esta etapa del desarrollo evolutivo de la raza humana, se encuentra como elemento de unidad e integración el deseo e instinto de supervivencia, el cual a su vez empodera y legitima al individuo cuya capacidad asegurare la supervivencia del colectivo. Este es y será el primer pilar de la integración.

Citando a Restrepo Abondano (1989, p. 84), quien realiza un análisis del modelo antropológico del pensamiento de Aristóteles en su obra La Política,

El hombre tiende naturalmente a asociarse: esa es la última explicación de los grupos familiares, aldeanos, y de la comunidad política. La Polis, por ser el único grupo social autárquico, es anterior a la familia y al individuo, que se encuentran en la misma relación en que se hallan las partes con respecto al todo.

Asimismo, el autor continúa desarrollando lo antes mencionado con los siguientes términos: “Al unirse los hombres, necesariamente aparece el fenómeno de la autoridad: unos mandan 
$\mathrm{y}$ otros obedecen. Cada forma de asociación demanda sus propias autoridades" (Restrepo Abondano, 1989, p. 87). ${ }^{68}$

En ese sentido, la base sobre la cual se constituyen las Polis es el "sinecismo", que según la definición de (Aguilera Barchet, 2014, p. 54) El término "sinecismo" (synoikism ós, literalmente "cohabitación") alude a un proceso histórico por el cual una serie de poblaciones aisladas se unen para protegerse mutuamente formando una ciudad-estado.

Este punto es muy importante, porque es a partir del caso de las Polis griegas que ya la integración trasciende de los individuos a los colectivos (basados en parentescos o vínculos de sanguíneos directos), a colectivos familiares a organizaciones político-administrativas.

Sin embargo, el mayor problema de las Polis es que solo servían para gobernar y administrar al interior de la ciudad, mas no lograron articular un modelo de expansión territorial. Incluso cuando el crecimiento demográfico hacia insostenible la administración de la Polis, se efectuaban expediciones para fundar nuevas colonias, las cuales en última instancia terminaban por ser independientes de la que vendría a ser la "Polis matriz" (Aguilera Barchet, 2014, p. 47).

\subsubsection{La economía como segundo pilar de integración}

Una vez garantizada la supervivencia del colectivo y habiéndose constituido las nuevas actividades económicas del hombre sedentario tales como la agricultura, la ganadería, la pesca, la orfebrería, metalurgia entre otras, es que comienza a materializarse el bienestar del colectivo, teniendo como prueba de dicho bienestar el aumento del número de miembros que componían la familia. Poco a poco esas familias comenzaron a tener cierta experticia en alguna de esas actividades, lo cual generó que otras, que tuvieran una experticia distinta a la primera, pudieran integrarse entre ambas en aras de obtener un complemento económico, una sinergia económica: La primera familia tenía la experticia de la agricultura - por dar un ejemplo-, mientras que la segunda, la experticia de la ganadería, al momento de combinar

\footnotetext{
68 Añadimos a ello, PROPIAS NORMAS, ya que toda convivencia entre individuos en sus múltiples niveles (familias, aldeas, comunidades, naciones, entre otros) conlleva a la existencia de un cuerpo normativo (consuetudinario o escrito) que regule y garantice la convivencia pacífica y el orden social, lo cual finalmente conlleva al bienestar general de todos los individuos.
} 
dichas actividades en beneficio de ambas familias, se lograba una mejora sustancial en la dieta y alimentación, generándose la posibilidad de cooperar, intercambiar bienes (trueque, comercio) con otras familias o colectivos de mayor tamaño y de esta forma obtener un mayor bienestar.

De esta forma, es que gracias al sedentarismo y las actividades económicas derivadas del mismo, es que poco a poco se comienza a generar un proceso de integración entre pequeños colectivos de personas, puesto que dichos colectivos descubren que en la integración económica con otros se vive mejor, en el comercio y la cooperación, dentro de un espacio común, es que se sientan las bases para el crecimiento económico y bienestar, el cual provoca a su vez un fenómeno de concentración territorial en virtud del cual, las pequeñas poblaciones se integran, poco a poco, en ciudades más grandes (Aguilera Barchet, 2014, p. 43); en ese sentido, la economía, teniendo como finalidad satisfacer el deseo natural por el bienestar que todo individuo posee, terminará siendo pieza o eje central no solo en los procesos de integración de colectividades primitivas o antiguas, contribuyendo significativamente en los procesos constitutivos de las organizaciones políticoadministrativas, sino en el Derecho de Integración mismo, ya que a través de la búsqueda del bienestar económico es que se van construyendo los procesos integradores entre Estados mediante este Derecho.

\subsubsection{La religión como tercer pilar de integración}

En la medida que van surgiendo nuevas colectividades y estas van aumentando en número de individuos que las componen, va a requerirse que las autoridades que las lideran no solo cuenten con las habilidades suficientes para garantizar la supervivencia del colectivo y de los individuos, sino de una fuente de legitimidad para su poder y autoridad, para ello se tomará el ejemplo de la civilización egipcia,

La egipcia no es una civilización urbana a diferencia de la civilización del valle del Indo. Las aldeas que surgen en torno a las riberas del Nilo hacia el 4,000 a. C., mil años después no han logrado convertirse en ciudades, a pesar de un exorbitante 
crecimiento demográfico. Por eso fue relativamente sencilla la unificación de Egipto bajo el poder teocrático de un faraón, el cual económicamente debía asegurar la supervivencia de su pueblo, ya que este dependía de la ordenación de los cultivos que propiciaban las crecidas anuales del Nilo. Para lo cual el faraón, un intermediario entre los hombres y la divinidad, gobernaba mediante "decisiones inspiradas", con lo que aseguraba la cohesión de la sociedad egipcia (Aguilera Barchet, 2014, p. 37).

Del ejemplo antes mencionado, se observa que mientras mayor sea la dimensión de la colectividad tanto en número de individuos como en extensión territorial donde esta se desarrolla, requiere de un sistema político sólido capaz de mantener la cohesión de la misma. Para ello la religión resultó vital para alcanzar dicho objetivo en tanto que el origen del poder, así como las fuentes de los diversos códigos morales o éticos, es decir cuerpos normativos, radicaban en elementos trascendentes a la naturaleza del hombre. Sin embargo, no se puede quedar solamente con la religión como fuente de legitimidad del poder de la autoridad, ya que esta cumple otro rol más importante ${ }^{69}$, el mantener la unidad dentro del colectivo, es decir la religión como elemento de unidad e integración de los individuos.

Como ejemplo a este último punto se encuentra a la nación judía, el cuál por muchos siglos vivió disperso por el mundo, siendo una nación sin territorio hasta 1948 que se funda el Estado de Israel,

La dimensión social - política y jurídica- de la Biblia es trascendental, pues permitió que, durante 18 siglos, los judíos sobreviviesen como pueblo, sin patria, dispersos por todo el mundo, y que a pesar de la "diáspora", el pueblo judío siguiese manteniendo su religión y su derecho, a pesar de no tener un territorio fijo. Un ejemplo único en la historia de cómo la religión puede convertirse en la base estructuradora de una sociedad y en fuente de su derecho (Aguilera Barchet, 2014, p. 82).

\footnotetext{
${ }^{69}$ Se afirma "más importante" porque si bien por muchos siglos la fuente de legitimidad del poder de las autoridades radicaba en Dios - el monarca gobernaba por voluntad divina-, con el desarrollo político-cultural de la humanidad, se observa como esta premisa pierde validez y la figura de Dios y la religión son reemplazadas por la razón y el pueblo como fuente del poder y legitimidad.
} 
Asimismo, la religión no solo termina manteniendo la cohesión social dentro del colectivo de personas, sino que, a su vez, termina influenciando y construyendo la cosmovisión de este, puesto que sienta las pautas ético-morales sobre las cuales los individuos y la sociedad desarrollarán su propia cultura.

A modo de ejemplo de lo antes dicho, se puede tomar el caso del cristianismo y su influencia en la construcción de la cosmovisión de occidente, ya que desde la caída del imperio romano de occidente, quien mantiene el orden social frente al vacío dejado por Roma, quien guarda y custodia las grandes obras de los pensadores de la antigua Grecia-cuna de la civilización occidental- fue la Iglesia Católica, por ello no es un despropósito afirmar que somos occidentales porque hemos sido cristianos, y es que en Occidente el cristianismo es algo más que una religión, es una parte esencial de nuestra cultura, que hunde sus raíces en la temprana cristianización de Occidente. Contribuyendo no solo con la organización y estructura de los Estados europeos, sino con los de América (Aguilera Barchet, 2014, pp. 81-82).

\subsubsection{La cultura como cuarto pilar de integración}

La cultura, como cuarto y último pilar de integración, termina siendo la culminación de un largo proceso que se va desarrollando paralela y paulatinamente con el desarrollo mismo del ser humano y los pilares de integración antes mencionados (instinto de supervivencia, economía y religión).

Acorde con la (Real Academia Española, 2016) se entiende por cultura:

2. f. Conjunto de conocimientos que permite a alguien desarrollar su juicio crítico

3. f. Conjunto de modos de vida y costumbres, conocimientos y grado de desarrollo artístico, científico, industrial, en una época, grupo social, etc.

No obstante, es pertinente realizar una definición propia que, para fines de la presente investigación, permitirá comprender la real dimensión de la cultura como elemento y pilar de integración, así como sus alcances e importancia en dichos procesos tanto de los individuos, como de las organizaciones político-administrativas. Por ello es que se considera 
a la cultura un conjunto de conocimientos, saberes (SUPERVIVENCIA - ECONOMÍA), costumbres, creencias y pautas de conducta de una colectividad de individuos (RELIGION), desarrollados en la interacción con el espacio geográfico -contribuyendo finalmente la adaptación con el mismo- y tiempo en el que habitan, así como el medio con el que satisfacen necesidades de todo tipo.

Habiendo dado una definición propia de qué es cultura, es importante explicar y fundamentar porqué a criterio nuestro la cultura termina siendo el cuarto y último pilar de integración, el cual es el resultado de un proceso concatenado con los pilares antes desarrollados.

a) Conjuntos de Saberes / Conocimientos: En lo que respecta de la definición de cultura al "conjunto de conocimientos y saberes", estos son el resultado del desarrollo humano logrado en los dos primeros pilares de integración: Supervivencia y Economía. Ello, porque dichos conocimientos y saberes se obtienen como parte de la interacción de los colectivos de individuos con su medio ambiente, buscando satisfacer el deseo de consolidar su supervivencia y obtener un mayor bienestar. Como ejemplo general, se puede considerar el idioma, ya que es gracias a este que los primeros colectivos pueden articular un medio de comunicación a través del cual establecen relaciones sociales y pueden transmitir ideas y conocimiento entre sus miembros. De manera más específica, se podría tomar como ejemplo a las construcciones de la cultura Inca con la arquitectura e ingeniería especializada en piedra, las cuales a su vez tenían un gran avance en resistencia antisísmica perdurando muchas de esas edificaciones hasta nuestros días, por encima de otras de origen virreinal edificadas por los europeos y que lamentablemente no pudieron resistir los movimientos sísmicos propios de los territorios próximos a la falla de Nazca-, permitiendo que se adapten a las difíciles características de la geografía de los andes (Rostworowski, 2013).

Por otro lado, como bien ya se ha desarrollado con la Economía como segundo pilar, es justamente la interacción e integración económica, que también se va construyendo la cultura, puesto que en esa interacción se produce una "simbiosis", un compartir y traspaso de bienes, experiencias y conocimientos entre colectivos de 
personas que, en aras de obtener un mayor y mejor bienestar, se integran y por consiguiente la cultura de ambos termina haciéndose una con ellos.

Como ejemplo a lo antes mencionado se puede hablar de la expansión Inca tanto en la costa sur, como centro y norte del actual Perú, donde el Inca buscaba la incorporación de reinos menores, tales como los Chimús o Chinchas, utilizando como medios la disuasión militar ${ }^{70}$ y la entrega de obsequios para lograr el reconocimiento como máxima autoridad e incorporarlos a su imperio, manteniendo la estructura y orden pre-existente, pero añadiendo otros elementos propios del Tahuantinsuyo tales como el quechua, dioses, tecnologías y productos propios del imperio; asimismo, el Inca incorporaba y difundía los avances tecnológicos y todos aquellos elementos de los reinos conquistados que pudieran nutrir, no solo en el aspecto económico, sino cultural al Tahuantinsuyo (Rostworowski, 2013).

b) Costumbres, creencias y pautas de conducta: Estos elementos de la cultura terminan desarrollándose gracias al tercer pilar de la integración: La religión, dado que esta tuvo un rol central en la construcción de las características culturales de los colectivos de individuos, en gran medida por establecer los parámetros morales, lo "bueno" y "malo", fijando las pautas de conducta humana, estableciendo costumbres y constituyendo creencias que finalmente influenciarían en la cosmovisión de dichos grupos. Esto a su vez se debe en gran parte -al igual como lo establecimos en el anterior punto) a la interacción que los seres humanos y los colectivos de personas tienen con el espacio geográfico y tiempo en el que se desarrollan, donde muchos de estos dioses terminan siendo personificaciones de los elementos de la naturaleza (sol, lluvia, luna, agua, tierra), como también representaciones o proyecciones de las aspiraciones y características de las personas mismas (mitología greco-latina), por eso es importante a los términos usados al comienzo del primer punto, siempre relacionarlo con el entorno geográfico y momento histórico en el que se analice.

\footnotetext{
${ }^{70}$ Acorde con varios autores, tales como Rostworoswski o Inca Garcilazo de la Vega, los incas antes de iniciar un enfrentamiento armado, iban con sus ejércitos para disuadir o intimidar a sus adversarios y que de esta forma acepten los presentes que ofrecía el Inca, bajo condición que se incorporen al Imperio.
} 
Es pertinente establecer que, si bien la religión en occidente tras la Ilustración, comenzó a tener un rol menos preponderante en la vida pública -incluso decreciendo el número de fieles o personas confesionales de determinado credo-, y política de los Estados, toda vez que Dios deja de ser el centro de la vida, para pasar al antropocentrismo, el hombre como centro del universo y por consiguiente la razón como fuente del saber y el conocimiento; nuestras pautas morales, nuestras ideas de bien o mal, si bien encuentran hoy por hoy su fuente en la razón humana, antes que la razón humana sea la fuente de ese conocimiento, la idea de un ser supremo y la "religión" terminó fijando los cimientos sobre los cuales nuestra razón -para quienes somos occidentales- finalmente termina estableciendo los conceptos de bien o mal.

Por ello, a pesar que la religión ya no cumple un rol central en la vida social de las persona y los Estados, su aporte es vital tanto en su espacio-tiempo en la que desempeñó un papel preponderante, así por el legado que esta estableció en la actualidad, siendo la base, el cimiento sobre la que la cultura reposa y da forma a nuestras sociedades; por estos motivos, es que sí es importante que los procesos de integración entre organizaciones político-administrativas -y actualmente Estadostengan por eje central a sociedades que compartan una cultura común, o como lo definiría Samuel P. Huntington, sean parte de una misma civilización.

Acorde con el referido autor, una civilización es una entidad cultural. Ciudades, regiones, grupos étnicos, nacionalidades, grupos religiosos, son entidades que tienen distintas culturas a diferentes niveles de heterogeneidad cultural (Huntington, 2001, p. 126).

Para poder comprender mejor lo antes citado, el autor establece el siguiente ejemplo:

La cultura de una ciudad del sur de Italia puede ser distinta de una ciudad de la Italia del norte, pero ambas tendrán en común una cultura italiana que las distingue de las ciudades alemanas. Las comunidades europeas compartirán, a su vez, rasgos culturales que las diferencien de las comunidades árabes o chinas. Pero árabes, chinos y occidentales no son ya; sin embargo, parte de ninguna entidad cultural más amplia. Constituyen Civilizaciones (Huntington, 2001, p. 126). 
Finalmente, el autor finaliza su definición de Civilización con la siguiente idea:

Una civilización es pues, la más elevada agrupación cultural de gentes y el más amplio nivel de identidad cultural que poseen los pueblos y que es en suma lo que distingue a los hombres de las demás especies. Una civilización se deja definir por elementos objetivos comunes, como son el lenguaje, la historia, la religión, las costumbres y las instituciones, y también, a su vez por las autoidentificación subjetiva de un pueblo (Huntington, 2001, p. 126).

¿Por qué los procesos de integración deben realizarse entre organizaciones políticoadministrativas de una misma civilización?

En primer lugar, por las semejanzas, tal como ya se desarrolló en el presente punto, en la medida que los elementos a integrar se sostengan en los mismos pilares de integración, el proceso será sostenible y viable en el tiempo.

En segundo lugar, porque es más fácil integrar, unir iguales; se puede integrar dos moléculas de agua de forma natural entre sí, pero naturalmente no puedes integrar una de agua y aceite por las características intrínsecas que estas poseen.

Y finalmente, porque organizaciones político-administrativas pertenecientes a distintas civilizaciones, terminarán confrontando entre sí por las diferencias naturales que estas llevan en sí mismas, tales como la historia, el idioma, y lo más importante, la religión.

Los pueblos que pertenecen a civilizaciones destinas tienen puntos de vista diferentes sobre las relaciones entre Dios y el hombre, el individuo y el grupo, el ciudadano y el Estado, entre padres e hijos, entre marido y mujer, e igualmente opiniones distintas sobre la relativa importancia de los derechos y las responsabilidades, de la libertad y la autoridad, de la igualdad y la jerarquía (Huntington, 2001, pp. 127-128). 


\subsection{Fases económicas del proceso de integración.}

Acorde con lo que se ha venido desarrollando en la presente investigación, los procesos de integración tienen fundamentalmente alcances políticos y jurídicos; sin embargo, la forma en la que estos se materializan se da a través de medidas económicas tangibles y concretas, por ello también es necesario hablar de integración económica.

La integración económica no es un fenómeno moderno: La moderna Alemania nace a través de una unión aduanera de Zollverein (Tamanes, 1990, p. 202) en 1834, que aglutinó siete estados germánicos. Italia es también el resultado de un esfuerzo de unificación económica llevado a cabo en 1861. Lo que sí nos diferencia de épocas pasadas, lo que hace de nuestro tiempo la "era de la integración" (Haberler, 1964) es la proliferación de ensayos integradores y de propuestas de integración que van de la integración regional que constituye Estados, a Estados que se integran en OS (Petit Primera, 2014, p. 138).

Acorde con (Petit Primera, 2014), la integración económica no es un hecho sino un proceso constituido por cinco fases ${ }^{71:}$ la zona o área de libre comercio, la unión aduanera, el mercado común, la unión económica y la comunidad económica o integración económica total.

Acorde con (Balassa, 1964) las cinco fases antes mencionadas tienen las siguientes características.

a) Zona de Libre Comercio: Es la primera fase, supone la eliminación de todas aquellas barreras -principalmente arancelarias- a las exportaciones e importaciones de bienes entre los Estados que componen la zona, sin perjuicio que cada miembro de esta zona, pueda mantener sus propias barreras y aranceles de forma independiente frente a terceros.

\footnotetext{
${ }^{71}$ Estas etapas consideran que la economía internacional es un fenómeno de tipo comercial, en la cual están contenido los siguientes aspectos: comercio de bienes y servicios, pagos internacionales, problemas monetarios, transporte y comunicaciones, finanzas y seguros, movilización de personas, etc.
} 
Acorde con Petit Primera,

El problema que se deriva de una zona de libre comercio es la necesidad de mantener controles fronterizos para los productos que procedan de países pertenecientes al área de libre comercio pero que hayan sido producidos total o parcialmente en el exterior; para tratar de evitar el problema se establecen "reglas de origen"72 de los bienes que se importan, de manera de diferenciar la procedencia de un producto y permitir a las autoridades portuarias saber qué producto amerita recibir las ventajas arancelarias. Por ejemplo, una regla es considerar bienes originarios de un área de libre comercio a aquellos que incorporan materiales procedentes del exterior, pero sin exceder 50\% del total del producto (Petit Primera, 2014, p. 141),

b) Unión Aduanera: Segunda fase, los Estados que conforman el área de libre comercio establecen un arancel externo común frente a terceros países.

\section{Siguiendo en la línea de Petit Primera,}

La unión aduanera requiere de mayores esfuerzos de negociación y acuerdo, ya que cada miembro puede ver modificada su estructura productiva, en mayor o menor grado, como consecuencia de decisiones comunes, bajo este esquema permanecen las barreras que impiden la libre circulación de los factores de la producción (Petit Primera, 2014, p. 141).

c) Mercado Común: Tercera fase, supone, la existencia de una unión aduanera, pero además requiere de la liberalización de los factores productivos, pues no se limita únicamente a las mercancías, como es el caso de las dos fases anteriores.

En este sentido, el mercado común implica la liberalización efectiva de mercancías,

\footnotetext{
72 Siguiendo con lo cita de (Petit Primera, 2014), el autor explica a las "reglas de origen" como los criterios necesarios para determinar la procedencia nacional de un producto. Su importancia se explica porque los derechos y las restricciones aplicados a la importación pueden variar según el origen de los productos importados.

(...) Las normas de origen se utilizan en los siguientes casos: al aplicar medidas e instrumentos de política comercial tales como los derechos antidumping y las medidas de salvaguardia; al determinar si se dispensará a los productos importados el trato de la nación más favorecida (NMF) o un trato preferencial; a efectos de la elaboración de estadísticas sobre el comercio; al aplicar las prescripciones en materia de etiquetado y marcado; por último, en la contratación pública.
} 
personas, servicios y capitales, por lo que no existen obstáculos a la entrada y salida de personas que se desplacen con una finalidad económica (empresarios y trabajadores) en ninguno de los Estados miembros (Petit Primera, 2014).

d) Unión Económica: Cuarta fase, supone un grado más avanzado en el proceso de integración económica regional. Además de la existencia de un mercado común, así como las anteriores fases, requiere de exista una armonización de las políticas económicas de los Estados miembros. La unión económica incluye la unión monetaria o de las paridades de las monedas, cuya fase más avanzada puede conducir a la circulación de una moneda única y a la instauración de una autoridad monetaria central, como es el caso, por ejemplo, de la Eurozona (Petit Primera, 2014).

Sobre las etapas antes mencionadas, es pertinente señalar, acorde con (Requeijo, 202), lo siguiente:

1) Las etapas de integración no se materializan de manera precisa y clara. Por razones de orden o taxonómicas, se ordena y enumeran en la presente clasificación que se enumera, pero la realidad demuestra que existen fórmulas intermedias con mezcla de características entre cada etapa.

2) Los procesos de integración económica por sus propias características e implicancias solo pueden tener dos desenlaces una vez iniciados: o bien el referido proceso se interrumpe, porque algunos miembros son incapaces de soportar los costos que este acarrea para su propia economía, o bien el proceso se mantiene en busca de una fase superior.

3) El desarrollo del proceso integrador económico y el paso de una etapa a otra es una decisión principalmente política que entraña costos y dificultades, por lo que no puede ser adoptada únicamente por los líderes y gobernantes de turno, sino que ha de ser entendida y refrendada por una mayoría de los ciudadanos que consideren beneficioso para sus propios intereses, así como para el país. 


\subsubsection{Objetivos de la Integración Económica.}

En la presente investigación se ha señalado ya los objetivos políticos que persiguen los procesos de integración; sin embargo, es menester enfocarse también en los objetivos económicos que estos pueden perseguir.

El principal, sino el mayor, objetivo está relacionado con las ganancias asociadas al libre comercio y a una ampliación de los mercados ${ }^{73}$, lo que permite una mayor división del trabajo en el seno del espacio integrado y, consecuentemente, una mejor asignación de recursos reales y financieros: será más fácil para las empresas obtener economías de escala y alcance, lo que debe permitir un mayor ritmo de crecimiento de las economías además de una mejora del bienestar general (Petit Primera, 2014).

En segundo lugar, el aumentar la competencia en el conjunto de los países partes de un proceso de integración, puesto que, a través de una mayor competencia, la inversión debe acelerarse y provocar una revitalización de las economías de bloque; también, de esa forma, debe acelerarse el ritmo de crecimiento y potenciarse el bienestar social.

Y finalmente, el empoderamiento de las economías de los países partícipes de un proceso integrador, puesto que por las propias características de la integración, al constituirse en un OS, este no solo tiene un mayor peso político en el escenario internacional, sino un mayor peso comercial y económico, que le permite hacer frente a otros actores internacionales en escenarios comerciales y económicos, en que los Estados que lo componen no podrían hacerlo de forma individual o por sus propios medios.

\footnotetext{
73 ¿Por qué se dice que los procesos de integración tienen como finalidad ampliar los mercados? Porque como bien lo señaló ya (Smith, 2001), la principal limitación al crecimiento económico es el tamaño limitado del mercado mismo, puesto que la economía solo crecerá hasta donde la demanda lo permita, por ello, para que el crecimiento sea constante, es necesario tener un umbral elevado de crecimiento para la demanda, por eso es que el libre comercio, el libre mercado, y más aún la integración económica, resultan mecanismos que dan solución al problema plantado por Adam Smith.
} 


\section{Capítulo 4: La Unificación Alemana como caso emblemático de integración}

Cuando se habla de la Unificación Alemana, es sin duda de un episodio trascendental, no solo de la Geschichte des deutschen Volkes (historia del pueblo alemán), sino de la historia del Derecho, puesto que es con este proceso, donde se demuestra el objetivo principal de la presente investigación: El D.I. tiene sus orígenes en la Política y es en el proceso de unificación germánico del siglo XIX, donde finalmente se hace una realidad jurídica y una herramienta en el escenario internacional.

Para ello, este capítulo se enfocará en el principal actor y motor del referido proceso, Prusia, puesto que, sin la capacidad de sus principales líderes, así como su efectiva geopolítica, la Confederación Germánica y posteriormente la Confederación Alemana del Norte, no habrían sentado el precedente de figuras efectivas de un proceso de integración y el Derecho que lo regula. En esa misma línea, tampoco se podría hablar de Alemania como Estado y principal actor internacional del último siglo y medio hasta nuestros días.

\subsection{El surgimiento de Prusia como actor internacional (s. XVIII-XIX): De la Guerra de Sucesión Española, a Federico II El Grande}

Para hablar de los orígenes de Prusia, hay que remontarse a los albores de los años 1415, donde el emperador Segismundo dio la marca de Brandeburgo a Federico Hohenzollern, un noble de la tierra de Nüremberg en el sur de Alemania, siendo finalmente esta dinastía la responsable por liderar el desarrollo político de este territorio (Ramos-Oliveira, 1973, pág. 121).

Brandeburgo fue uno de los siete electores que escogían al emperador del Sacro Imperio Romano Germánico (Garcés Ávalos, 2016); para 1594, con el matrimonio del elector de Brandeburgo, Juan Segismundo y la duquesa Ana de Prusia, se da la unión de estos dos territorios constituyéndose como uno solo (Clark, 2006). No obstante, el verdadero creador del Estado de Brandeburgo-Prusia fue Federico Guillermo (1640-1688) dado que constituyó 
un ejército no excesivamente numeroso pero disciplinado y eficaz con el que logró hacerse respetar (Ramos-Oliveira, 1973, p. 122).

En el siglo XVII, Prusia inicia un proceso que lo enrumba a consolidarse como EstadoNación. Ya en 1701 participó en la hasta entonces mayor conflagración bélica europea de la época, que fue la Guerra de Sucesión Española (1701-1713). A cambio del apoyo que brindó el Elector Federico III de Brandeburgo al emperador Leopoldo I en la mencionada guerra, este último le permitió coronarse "Rey en Prusia", lo cual elevó la categoría del mencionado príncipe, si bien jurídica y nominalmente se mantenía como vasallo del emperador, y por ende sus territorios como parte integral del Sacro Imperio Romano Germánico (Clark, 2006).

El Tratado de Utrecht (1713), que puso fin a la Guerra de Sucesión Española, confirmó el título real de Federico I de Prusia, y su participación en dicho conflicto internacional colocó al pequeño Estado prusiano dentro de los actores internacionales de la época ${ }^{74}$. Si bien su realeza estaba reducida a territorio prusiano, el debilitamiento de la autoridad imperial sobre los principados que conformaban el Sacro Imperio Romano Germánico permitió que, de facto, el Electorado de Brandeburgo fuera tratado como parte del reino prusiano y no como una entidad política separada (Shennan, 1995).

Para la época en la que sucedió a Federico I su hijo Federico Guillermo I (1713-1740), todavía no se podía hablar de un Estado absolutista, pues en los territorios que este gobernaba, como Brandeburgo, Prusia y Cleves, existían dietas o parlamentos que fijaban y definían sus propios impuestos y fiscalizaban los gastos (Ramos-Oliveira, 1973, p. 123). Esta situación significaba una amenaza a la intención del segundo rey prusiano por modernizar Brandeburgo-Prusia, puesto que para esa época ya los grandes reinos europeos estaban constituidos bajo un modelo absolutista y unificado en el poder del soberano, consolidando el triunfo de la monarquía absoluta sobre el feudalismo, lo cual permitía centralizar la administración y el gobierno en una sola persona y/o institución. Por ello Federico Guillermo introdujo una serie de reformas tratando de desplazar el modelo feudal -donde los grandes nobles o señores feudales constituían las diversas dietas o parlamentos

\footnotetext{
${ }^{74}$ Curiosamente el duque de Saboya, Víctor Amadeo II, recibió un beneficio similar al del rey prusiano, al ser reconocido primero rey de Sicilia y luego rey de Cerdeña, elevando su categoría entre los monarcas de Europa. Es decir, estos dos pequeños principados lograron con el fin de la guerra, elevar su categoría al de reinos.
} 
de cada territorio- a uno absolutista, consiguiendo finalmente unificar toda la administración pública en un sistema mucho más centralizado para los territorios, así como instaurar un ejército permanente y profesional -lo cual para su época fue una medida sumamente vanguardista (Shennan, 1995).

Las reformas de Federico Guillermo permitieron que su sucesor Federico II llevase a Prusia a su apogeo, en especial tras el debilitamiento de los Habsburgo en Alemania, en el marco de la Guerra de Sucesión Austriaca (1740-1748). Aprovechando las múltiples amenazas con las que la heredera del emperador Carlos VI y nieta de Leopoldo I tuvo que lidiar, en especial la amenaza bávara, Federico II se lanzó a una de sus principales campañas militares: La conquista de Silesia (Clark, 2006).

Este episodio significó para Federico II, y en especial para el pequeño reino de Prusia, la oportunidad de ampliar sus fronteras y sus dominios, aprovechando el debilitamiento de la emperatriz María Teresa de Austria, quien había recientemente asumido el trono, la cercanía con sus fronteras, así como la conexión con su territorio a través del río Oder, otorgándole una región rica en recursos mineros (Voltes, 2006, pp. 57-59).

El conflicto que siguió al mencionado anteriormente fue la Guerra de los Siete Años (17561763), el cual se caracterizó por las redes de alianzas atípicas originadas en el marco del conflicto; por la alianza anglo-prusiana mediante la cual Prusia buscó evitar quedar aislada frente a la coalición austro-ruso-francesa, y a un nivel más global por la transformación radical del mapa colonial europeo, aunque ello no implicase modificaciones territoriales a Prusia (Voltes, 2006).

El acercamiento de dos enemigos tradicionales, como Austria y Francia, significaba una constante amenaza para Prusia y fue el factor principal del acercamiento diplomático de Federico II con la Gran Bretaña de Jorge II y su Primer Ministro William Pitt (1759-1806). En lo que atañe al incremento de la actividad bélica prusiana, en 1756 Federico II invadió Sajonia, aliada de Austria y la saqueó. Pese al apoyo del ejército imperial austriaco, el elector de Sajonia partió rumbo a Polonia donde era rey. Al año siguiente, Federico II atacó Bohemia, posesión de los Habsburgo, pero la campaña resultó un fracaso y los austriacos 
contuvieron a Federico, mientras que los franceses derrotaron a sus aliados ingleses (Voltes, 2006)

A fines de 1757 y pese a los reverses militares sufridos, Federico triunfó sobre austriacos y franceses en las batallas de Rossbach y Leuthen (5 y 24 de noviembre, respectivamente). Si bien su genio militar y hábil tacto diplomático le permitieron evitar el cerco de sus enemigos, al año siguiente la ofensiva austro-ruso presionó aún más a Federico. En 1760, los rusos entraron en Prusia y ocuparon Berlín (Clark, 2006; Ramos-Oliveira, 1973)

Los estragos de la guerra pronto se hicieron sentir, sobre todo en lo que concierne al agotamiento de los ejércitos. En el año 1761 prácticamente no se registran movimientos bélicos a larga escala, y en Londres un cambio de gobierno propició la caída de William Pitt, aliado de Federico II, siendo reemplazado por un gobierno de tendencia pacifista apoyado por el nuevo rey Jorge III. De esta manera Federico quedó privado de uno de sus principales aliados (Voltes, 2006).

En el ámbito de la política internacional, pocas veces suceden hechos fortuitos que se podrían calificar de "milagros" para determinados actores; en el presente caso, la muerte de la zarina Isabel de Rusia (1762) produjo un cambio de régimen que elevó al trono a su sobrino Pedro III, de origen alemán y tendencias prusianófilas. El nuevo zar admiraba a Federico II y pronto ordenó a sus ejércitos a evacuar los territorios ocupados y sumarse a los ejércitos del rey prusiano, llegando incluso a firmar la paz y una alianza ofensiva y defensiva a la cual se sumó Suecia. Por todo lo antes dicho, este hecho fue el "milagro prusiano" (Clark, 2006; Voltes, 2006).

Ese mismo año, Francia firmó las preliminares de la paz con Gran Bretaña y sus tropas abandonaron territorio alemán. Para febrero de 1763, una fortalecida Prusia firmaba la paz con el imperio en Hubertusburg, sobre la base del statu quo ante bellum, consolidando el dominio prusiano sobre Silesia. Asimismo, en Paris, la Gran Bretaña, Francia y España firmaban la paz, reconfigurando el mapa colonial mundial (Clark, 2006).

Las campañas de Federico II y sus anexiones territoriales dieron a Prusia un peso político de relevancia en el escenario internacional. Lo que nació como un pequeño Electorado germánico, se consolidó en el siglo XVIII como un poderoso Estado-Nación, de fuerte 
tendencia militarista, que en un corto plazo desestabilizó la configuración inicial del panorama centroeuropeo, provocando de esa forma alianzas tan inusuales como las de Austria con Francia y Rusia (Voltes, 2006).

Tras 1763 el rey de Prusia ya no participó en más conflictos, y prefirió continuar con la organización de su Estado. Sólo en 1772, con la adquisición de parte de Polonia, Prusia vio alterada una vez más su composición territorial, naturalmente en beneficio de las ambiciones de su intrépido monarca (Voltes, 2006).

El legado de los primeros reyes prusianos radica en el posicionamiento de su joven Estado en el panorama político internacional de la Europa del siglo XVIII. Ello se produjo en el marco de sus planes geopolíticos, en tanto que, habiendo reconocido sus limitaciones geográficas y de recursos, propiciaron una política expansiva que encontró su mejor herramienta en la militarización del Estado y una acción exterior agresiva en contextos determinados (grandes conflagraciones, crisis dinásticas, etc.), aprovechando la complejidad de las circunstancias para alcanzar sus objetivos e imponiendo sus intereses.

Quizá la frase que sintetiza de forma concreta el desarrollo militar prusiano es aquella atribuida a un célebre ministro de Federico II, Friedrich von Schrötter (1743-1815), quien señaló que: "Prusia no era un estado con un ejército, sino un ejército con un estado".

\subsection{Las Guerras Napoleónicas y el Congreso de Viena: bases de la unificación alemana.}

Tras la muerte de Federico II, lo sucede su sobrino Federico Guillermo II (1786-1797) como rey de Prusia, hombre dotado de un brillante intelecto, aficionado a las artes pero de carácter fácil y amante de los placeres (Clark, 2006)

Una de las primeras medidas tras su ascenso al trono, (el 17 de agosto de 1786), fue la de aligerar la presión sobre el pueblo, reformando el sistema tributario, introducido por Federico II e incentivando el comercio con launa disminución de los derechos de aduana, así como la construcción de caminos y canales (Clark, 2006). 
Al ser el ejército el verdadero fundamento del Estado prusiano, los monarcas atendían con especial interés las condiciones en las que este se encontraba; sin embargo, el gran error de Federico Guillermo II fue el no continuar con la misma actitud que sus predecesores, puesto que los asuntos militares no eran temas de su preferencia o interés. Es importante destacar el difícil contexto en el que le tocó gobernar, que fueron los albores de la Revolución Francesa ${ }^{75}$.

Tal negligencia mermó la capacidad de reacción de Prusia en el escenario internacional, dado que mientras la Francia de Napoleón Bonaparte modernizaba su ejército con pertrechos, equipamientos y tácticas, el ejército prusiano, estaba mal equipado para hacer frente a la amenaza de la Francia revolucionaria. La oficialía prusiana retuvo los mismos entrenamientos, tácticas y armamento utilizado por Federico el Grande unos cuarenta años antes. En comparación, el ejército francés fue desarrollando, bajo la guía de Napoleón, nuevos métodos y formas de suministro, organización, mando y movilidad (Clark, 2006).

En agosto de 1791, Federico Guillermo II pactó con el emperador Leopoldo II de Austria para unirse a la causa de apoyo al rey Luis XVI de Francia; sin embargo, las finanzas prusianas, las cuales se encontraban mermadas por las extravagancias del monarca y el costo de sus reformas, no garantizaban que dicho apoyo para el rey de Francia fuera a tener el éxito esperado. El 7 de febrero de 1792 se firma formalmente la referida alianza, tomando parte personalmente en las campañas de 1792 y 1793 Federico Guillermo II para contener la revolución.

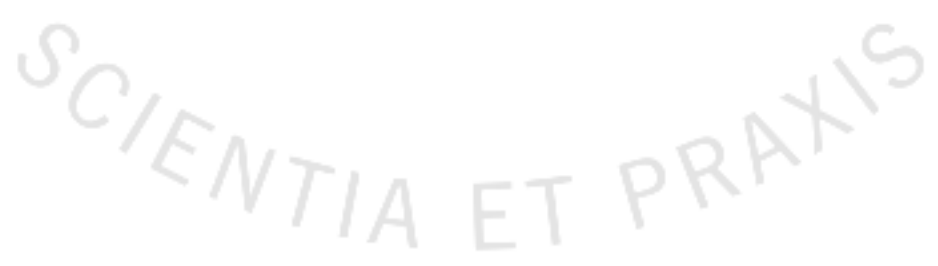

\footnotetext{
75 La Revolución Francesa fue un conflicto político-social, caracterizado por la violencia y crueldad de las masas, dirigido contra lo que sus principales líderes denominaron "Antiguo Régimen" (el régimen absolutista de Luis XVI (1774-1789. Dicha revolución, que encontró sus causas en el descontento popular por la enorme carga impositiva, malas cosechas que desencadenaron en hambrunas, y el desgaste del erario público, buscó dar mayor poder al pueblo mismo, a través de un modelo republicano, entendiendo que el poder proviene del pueblo gracias a la razón humana y no por la obra y gracia de Dios. Por ello los valores de igualdad, fraternidad y libertad, trascendieron a las fronteras de Francia, siendo esta una amenaza para los demás regímenes absolutistas de toda Europa, haciendo que una revolución nacional, termine involucrando actores internacionales en el conflicto en sí.
} 
El rey de Prusia se comprometió en la guerra al lado del emperador, pero más por temor al contagio revolucionario que por fidelidad: más por solidaridad dinástica que patriótica (Ayçoberry, 1988, p. 12).

El choque de rechazo de la Revolución Francesa les dio motivo de reflexión sobre el estado de su propia nación para los pueblos germánicos, pues la cuna de la idea nacional alemana es ante todo el medio conservador (Ayçoberry, 1988, p. 13) y esta revolución, de corte liberal significó no solo una amenaza al status quo, sino también una oportunidad para plantearse el nacimiento de una Alemania; sin embargo, el gran problema a esta disyuntiva se basaba bajo el liderazgo de quién es que se lograría unificar a los pueblos germánicos.

El choque de la Revolución Francesa no fue suficiente para suscitar una conciencia política: los más lúcidos, como Hegel, que en 1802 soñaban con una "Constitución Alemana" centralizada, reconocen que Alemania tiene necesidad de un conquistador que construya su unidad, con ella o contra ella (Ayçoberry, 1988, p. $15)$.

En un primer momento la campaña aliada comenzó con fortuna, para 1793, los franceses fueron expulsados de Bélgica, reconquistando Prusia Mainz y Alsacia. En el Sur, la presencia de una escuadra inglesa bastó para que se entregue la base naval de Tolón (RamosOliveira, 1973, p. 185).

Este avance duró poco, puesto que ese mismo año los franceses recuperaron Tolón, al tiempo que en París y las provincias el pronto famoso Carnot organizaba, con el nuevo ejército de la revolución, la victoria futura. Para 1794, los franceses tomaron de nuevo Bélgica, Holanda, Alsacia y zonas del Rin (Ramos-Oliveira, 1973, p. 185).

El éxito de estas victorias se debió en gran parte a las discordias entre Austria y Prusia, quienes, alarmadas por las pretensiones rusas sobre Polonia, vieron como una mayor amenaza las pretensiones de Catalina II sobre dicho territorio que al ejército francés. Motivo por el cual Federico Guillermo II se retiró de la alianza y abrió por su cuenta las negociaciones con Francia que culminaron con la paz de Basilea.

Cuando después de tres años de derrotas y con la perspectiva de una nueva partición de Polonia le condujeron a la firma de la paz de Basilea (1795), aceptó 
anticiparse a las furas decisiones del emperador, previendo en un artículo secreto que la orilla izquierda del Rhin continuara siendo francesa (Ayçoberry, 1988, p. 12).

Por este tratado Prusia perdió territorios en la orilla siniestra del Rin a cambio de que se reconozca su neutralidad el norte de una línea imaginaria desde el Rin hasta Silesia. Cerrando el frente francés, es que los prusianos pudieron negociar la partición de Polonia junto con los rusos y austriacos (Ramos-Oliveira, 1973, pp. 185-186; Clark, 2006).

Estaba previsto en todos estos textos, que los príncipes expulsados por Francia serían indemnizados por el resto del Imperio; todo demuestra pues, que a los ojos de sus dos más importantes potencias -Austria y Prusia-, Alemania solo era un tablero, con ello Bonaparte se sintió más estimulado a continuar reforzando sus intervenciones hasta el Rhin e incluso hasta más allá: "Si el Cuerpo germánico no existe, decía, debemos crearlo" (Ayçoberry, 1988, p. 12-13)

No obstante, la paz de Luneville (1801),

Preveía que los príncipes desposeídos en Renania serían indemnizados con los bienes eclesiásticos. Al mostrarse la Dieta incapaz de satisfacer todas las ambiciones, fueron Francia y Rusia, potencias “perfectamente desinteresadas”, las que impusieron sus opiniones. Las de Bonaparte fueron puramente estratégicas y diplomáticas: consiguió atraerse a Prusia sin acercársela demasiado al Rhin, y cediéndole obispados y abadías de Westfalia; aisló a Austria extendiendo Baviera hasta el Main; y, sobre todo, favoreció al conjunto de los estados medianos, cuyas rivalidades y clientelas le serían más provechosas que el griterío de los antiguos principitos.

Cuando la Dieta incorpora estas transformaciones en la sesión de 1803 se da forma a una nueva "Alemania":

Menos de la mitad de estados, 6 ciudades libres en lugar de 52, 2 principados eclesiásticos en lugar de 34. Prusia recibió 3 veces más de lo que había perdido; Baviera perdió 600000 habitantes, pero ganó 900 000; Baden ganó 200 000; Hesse-Darmstadt 100 000, etc. Todavía no es la unidad, pero es una enorme simplificación (Ayçoberry, 1988, pp. 16-17). 
Mantuvo durante los primeros años de su reinado una política de neutralidad heredada por su padre durante el transcurso de las Guerras Napoleónicas, manteniéndose incluso neutral frente a la Tercera Coalición de 1805; sin embargo, terminaría entrando en guerra contra el recientemente proclamado Imperio Francés, en octubre de 1806. Esta guerra significó para los prusianos una gran humillación, puesto que con la derrota en la Batalla de JenaAuerstädt, el rey y su familia tuvieron que huir hacia Prusia Oriental (Clark, 2006).

Estas derrotas para Prusia fueron consecuencia de la negligente política militar de Federico Guillermo II, motivo por el cual el nuevo rey entendió la necesidad de tomar medidas concretas para revertir las adversas condiciones. Entre las medidas que más resaltan se encuentra la creación del Ministerio de Guerra en 1809, así como la fundación de una escuela militar, dedicada a la formación de oficiales, conocida como la Academia Prusiana, en Berlín en 1810 (Clark, 2006).

Mientras estas reformas se venían efectuando, muchas voces clamaban por un accionar más decidido por parte del Prusia en el marco de las guerras napoleónicas; sin embargo, y a pesar de algunos levantamientos aislados dentro del ejército prusiano, la Corona mantuvo su neutralidad allá por los años 1809 .

\subsubsection{De la Confederación del Rhin a la Confederación Germánica: Teoría de la gravitación política de los Estados}

La hegemonía francesa, en el marco de las guerras napoleónicas, terminó por poner fin al Sacro Imperio Romano Germánico (agosto de 1806), provocando su defunción más emoción de la prevista, pues su arquitectura anticuada y medieval volvía a tomar justo en este momento cierto esplendor gracias a los románticos (Ayçoberry, 1988, p. 17). Sin embargo, dada la compleja y plural organización política de los pueblos alemanes, el fin del imperio, el cual ayudaba a organizar y de alguna manera simplificar la esta compleja estructura, dio paso al nacimiento de una nueva organización: La Confederación del Rhin (1806-1813) la cual organizaba a los reinos y ducados de proporciones medianas, dejando fuera de esta a las dos grandes potencias principales: Austria y Prusia. 
¿Y esto por qué? Para dar respuesta a esta interrogante se ha esbozado en la presente investigación, una teoría a la cual se ha llamado "Teoría de la Gravitación de los Estados", la cual consiste en que Estados grandes o poderosos, generan una fuerza de influencia similar a la gravedad, haciendo que Estados más pequeños giren en torno a este y finalmente actúen acorde con la influencia del primero. No obstante, a mayor fuerza o influencia, mayor la posibilidad que estos Estados más pequeños terminen siendo absorbidos por el grande o $\operatorname{poderoso}^{76}$

Si esta teoría se contrasta en el presente caso, se observa que las pretensiones de Napoleón fueron las de poder establecer una zona de influencia dónde ejercer su control sobre los territorios alemanes (es decir, que estos Estados más pequeños “orbiten” en torno a los intereses de Francia); sin embargo, si en esta ecuación, incorporaba a un tercer Estado de mayor poder o dimensión (Prusia o Austria), estos hubieran generado una contra-fuerza que mermara los intereses franceses, más aún porque estos pequeños Estados germánicos poseían mayores similitudes étnicas, históricas, culturales, entro otros factores, con los dos antes mencionados, haciendo mucha más fácil y sencillo orbitar entorno a estos antes que con Francia por existir más elementos comunes que solo el poder económico o militar.

\subsubsection{La Zollverein: inicios de la unificación alemana bajo el liderazgo de Prusia.}

La estructura y organización de la Confederación del Rhin dada por Napoleón Bonaparte, terminaría generando las condiciones para que se diera años más tarde la Zollverein, no solo entre estos pequeños y medianos reinos y ducados, sino teniendo como principal actor y responsable de esta unión aduanera a Prusia. La estrategia económica de Napoleón parecía

\footnotetext{
76 Para explicar mejor el referido punto, se pondrá como ejemplo al planeta Tierra y su satélite la Luna. Si se comparan ambos cuerpos celestes, la Tierra tiene mayor tamaño y por ende mayor gravedad o fuerza de atracción que la Luna, la cual también tiene su propia fuerza de atracción; sin embargo, al ser la fuerza de la Tierra mayor a la de la Luna, esto genera que la Luna tenga una órbita entorno al primero y no al revés, dándose cierto "equilibrio", en donde la Luna existe por sí misma, pero orbitando en torno a la Tierra. Ahora bien, si la fuerza de la tierra aumentara más, se rompería el referido equilibrio y la Luna terminaría por colisionar con la Tierra volviéndose ambos un solo cuerpo celeste, de mayor tamaño y mayor fuerza de gravedad.
} 
más coherente: prohibir los productos británicos y asegurar el dominio de los productos francés. Pero la combinación de estas dos medidas transformó el espacio económico alemán mucho más de lo que se podía prever (Ayçoberry, 1988, p. 18).

El prohibir los productos británicos provocó un desplazamiento de las corrientes comerciales, Hamburgo se arruinó: su comercio entre Inglaterra y el resto de Europa desapareció a partir de la ocupación francesa, llevando a que las mercaderías británicas terminen ingresando a Europa por Dinamarca (Ayçoberry, 1988, p. 19).

La política económica de Napoleón es también el sistema continental que pretende organizar el mercado europeo como salida para los productos franceses. Así las únicas regiones alemanas que se aprovecharon del desarrollo económico fueron, de un lado Sajonia, demasiado alejada para sufrir la competencia francesa y al mismo tiempo liberada de la de Inglaterra, y del otro lado Renania, integrada al espacio económico francés. Esta vio como prosperaban las explotaciones hulleras y la pequeña metalurgia cerca de Aquisgrán, las sederías en Crefeld y los tejidos de algodón en Colonia; en total trescientas nuevas empresas, con mano de obra y capitales a menudo transferidos desde la orilla derecha; en 1810 se puede decir que

"el departamento del Roer (Rhur) es el más industrializado de europa" (Ayçoberry, 1988, p. 19).

No sería sino hasta la retirada napoleónica de Rusia en 1812 cuando Prusia rompería la forzada alianza franco-prusiana, uniéndose a la sexta coalición.

A principios de 1813, los resto de la Grande Armée regresan de Rusia, el rey de Prusia se deja finalmente convencer y firma el 27 de febrero la alianza con el zar, lanzando el 17 de marzo su célebre llamamiento, en el cual el problema nacional es eludido: "No queremos dejar de ser prusianos y alemanes" (Ayçoberry, 1988, p. 30).

Las tropas prusianas lideradas por los generales Blücher y Gneisenau fueron de vital trascendencia en las batallas de Leipzig (1813) y Waterloo (1815) (Clark, 2006).

Con el fin de Napoleón, se generó un auge en el sentimiento nacionalista del pueblo alemán, suscitando a que muchos intelectuales comenzaran a escribir literatura patriota haciendo hincapié en la unión de Alemania “Que no se hable más de Austria y de Prusia, de Baviera 
y del Tirol, de Sajonia y de Westfalia, sino de Alemania" (Ayçoberry, 1988, pp. 30-31). Asimismo, surge la imperiosa necesidad por reordenar todo el caos que las guerras napoleónicas habían sembrado a lo largo y ancho de toda Europa, motivo por el cual se constituye el Congreso de Viena (1814-1815).

El Congreso de Viena fue un encuentro internacional cuyo objetivo fue el de restablecer las fronteras de Europa tras la derrota de Napoleón Bonaparte, así como la de reorganizar y replantear las ideologías políticas del Antiguo Régimen. La finalidad era que Europa retorne a la situación anterior a la Revolución francesa (1789), no sólo restableciendo las fronteras nacionales modificadas hacía casi 20 años, sino además para asegurar un equilibrio de poder que evitase otra serie de conflictos armados a gran escala, como fueron las Guerras revolucionarias francesas y las Guerras Napoleónicas. Sin embargo, si bien las fronteras fueron restablecidas, la simplificación de los territorios alemanes, reunidos en la Confederación del Rhin, se mantuvo, aunque con ciertas variaciones.

Ahora pasaría a llamarse Confederación Germánica incorporándose a los dos grandes Estados germánicos ausentes en la otrora Confederación del Rhin: Austria y Prusia, siendo estos los que finalmente terminarían por ser los que competirían entre ambos por consolidar su poder e influencia dentro de la nueva confederación ya que no estaba Francia como principal potencia sobre la cual los medianos y pequeños Estados germánicos orbitaban alrededor de estos.

La Confederación Germánica estaba destinada a mantener el equilibrio entre los estados, no nace de golpe, con el entusiasmo, sino fruto de laboriosas negociaciones (1815-1820). No es un estado, sino una Liga (Bund) entre "príncipes y ciudades libres" (...).

No es una alianza muy sólida: el tratado tiene concretamente dos objetivos: seguridad e independencia de los contratantes, pero la defensa contra los peligros exteriores queda en un segundo plano; el ejército confederal no se organiza hasta 1821 por la simple yuxtaposición de cinco cuerpos de ejército sin jefe: tres austriacos tres prusianos, uno bávaro y tres mixtos (...).

Finalmente, se le podría definir como una sociedad de seguros mutuos contra los trastornos internos; está previsto que a petición de un soberano, o incluso sin 
demanda si está impedida, la Dieta ${ }^{77}$ podrá proceder a una "intervención" para restablecer el orden en un estado y si en algún caso el mismo soberano quisiera separarse del camino recto, podría verse amenazado por una "aplicación confederal” (...) "unidad para el exterior, diversidad para lo interior" (Ayçoberry, 1988, p. 35).

Como se puede observar, es gracias a las injerencias napoleónicas, que se propician las condiciones para que se diera paso, años más tarde, a la integración germánica, puesto que es con Napoleón que el número de actores internacionales germánicos se reduce, al reducir esta enorme pluralidad, es más fácil organizar y estructurar a los estados germánicos que subsisten. Asimismo, es gracias a este personaje histórico y a Francia que se observa cómo se materializa el primer pilar sociológico de la integración: la supervivencia. Ya que, de la experiencia sufrida bajo los embates y medidas impuestas por esta última, es que los Estados germánicos supervivientes encontraron en la integración el mecanismo sobre el cual podían aumentar sus chances de supervivencia dentro del escenario internacional y no volver a ser eliminados o bien subyugados bajo la órbita de un actor internacional que no tuviera relación o semejanza alguna con estos. Muestra de ello se observa también en el tratado fundacional de la Confederación Germánica, que establecía fines defensivos, tanto para frentes externos como internos de cada uno de los actores partícipes de esta

(...) está previsto que, a petición de un soberano, o incluso sin demanda si está impedida, la Dieta podrá proceder a una “intervención” para restablecer el orden en un estado y si en algún caso el mismo soberano quisiera separarse del camino recto, podría verse amenazado por una "aplicación confederal” (...) "unidad para el exterior, diversidad para lo interior" (Ayçoberry, 1988, p. 35)

Como bien se ha mencionado anteriormente, es en este punto que se encuentra el primer precedente histórico a un OS dentro del marco del DI, en donde se observa cómo los Estados miembros, acordaron por considerarlo beneficioso para sus intereses y para garantizar su supervivencia en el escenario internacional -los cuales hacía pocos años habían padecido las invasiones napoleónicas- ceder parcelas de soberanía en lo que a seguridad exterior e interior respecta en favor la Confederación Germánica, pero manteniendo su soberanía o

\footnotetext{
${ }^{77}$ La Dieta, que no era un parlamento de representantes elegidos por el pueblo, sino un congreso de delegados con sede en Fráncfort
} 
autonomía en otras materias, con este caso se comprueba lo antes desarrollado en la presente investigación, en que el tratado constitutivo es la materialización del pacto social internacional, receptora de la soberanía de los Estados para los campos y alcances que estos de forma libre y soberana, por considerarla beneficioso para sus intereses, cederán sus competencias en los campos que consideren pertinentes en un OS que será finalmente quien actúe e imponga el derecho creado sobre sus miembros constitutivos.

Habiéndose constituido la Confederación Germánica, y consolidado el primer pilar sociológico, se dio paso al segundo pilar, el económico.

En 1815, las murallas del sistema aduanero napoleónico fueron derribadas y la nueva confederación germánica no se preocupó demasiado para edificarlas de nuevo. El mercado alemán se encontró así literalmente expuesto a todas las tempestades, fue una invasión de productos manufacturados, procedentes sobre todo de los stocks que Inglaterra había ido acumulando los años precedentes (Ayçoberry, 1988, p. 45).

Producto de esta situación, es que se observa cómo Prusia, a través del sistema de aduanas buscaría revertir esta situación y consolidarse como centro de integración económico de la Confederación.

La primera etapa consiste en unificar las provincias prusiana, separadas unas de otras por sesenta aranceles diferentes, quedando las del oeste abiertas al extranjero. En 1816 se abolieron todas las tasas sobre la circulación interior. En 1818 se fija un arancel uniforme en la frontera; pero los derechos de aduana continúan siendo moderados y, por otra parte, proporcionales al peso de las mercancías importadas, lo que satisface muy poco a los fabricantes, cuya materia se les encarece sin que la competencia británica sobre los productos acabados se vea muy afectada por ello (Ayçoberry, 1988, p. 46).

Por otra parte, Prusia gravaba todas las mercancías de tránsito con un arancel bastante elevado, encontrándose un formidable "garrote" económico y político, destinado a los otros Estados alemanes, los cuales comparaban al rey de Prusia como un "Barón saqueador" de la Edad Media y reclamaban a la Dieta ponga una política aduanera ciertamente alemana 
(Ayçoberry, 1988, p. 46). Estas medidas tan duras por parte de Prusia para los otros estados germánicos, dentro del marco de la Confederación Germánica no van acorde con el "espíritu solidario" que todo proceso de integración lleva consigo, se entiende porque a través de estas medidas, estaba generando las condiciones necesarias para que Estados de menor envergadura y peso político-económico, sintieran la necesidad de una integración no solo defensiva, sino económica para que no se viera perjudicada la industria nacional de cada Estado. Por ello,

De 1819 a 1828 Prusia propuso o impuso tratados bilaterales a una serie de estados, en primer lugar, minúsculos y luego pequeños y medianos. Se trata a veces de enclaves dentro de su territorio, cuya desaparición acortaba las líneas aduaneras, o a veces de etapas situadas en una gran vía comercial, como los tres ducados de Anhalt, a un lado y otro del Elba; a veces incluso de economías concurrentes (Hesse-Darmstadt), pero cuya integración demostraba a la opinión pública que Prusia sabía aceptar sacrificios. Los instrumentos fueron brutales: bloqueo de Anhalt durante tres años, corte total entre el norte y el sur, lo que acentúo la gravedad del marasmo general. Pero la victoria fue generosa: los gravámenes y los ingresos de las aduanas fueron repartidos a prorrata entre la población, manteniendo el vencido el derecho de veto sobre las decisiones comunes (Ayçoberry, 1988, p. 47).

Este tipo de políticas económicas tan agresivas, pero eficientes para los intereses de Prusia, que, frente a la falta de necesidad de pequeños Estados para orbitar en torno a sus intereses económicos, este los generaba imponiendo su poder y fuerza, creando la necesidad de esos más pequeños, también generó que Estados con mayor extensión y poder que los antes mencionados, busquen establecer coaliciones al interior de la Confederación, para debilitar el poder económico prusiano.

Los años 1829-1830 el elector de Hesse-Cassel, que "se creía el punto neurálgico de la política europea" considero útil suscitar una "asociación intermedia" de 17 estados que iban desde Bremen hasta Sajonia. Su idea era la de profundizar aún más la separación entre las provincias prusianas del este y del oeste, y concentrar el tráfico norte-sur en la ruta Bremen-Hannover-Cassel-Frankfurt (Ayçoberry, 1988, p. 47). 
Sin embargo, la respuesta Prusiana fue brillante: firmó con los Estados del sur un acuerdo muy favorable para ellos y construyó otro ramal norte-sur que aseguraba la continuidad de la ruta Hamburgo-Magdeburgo-Nuremberg. De esta forma todo el centro alemán corrió el peligro de ver como se agotaban sus fuentes de tráfico, quedando eliminada la "asociación intermedia" (Ayçoberry, 1988, pps. 47-48).

Es pertinente tener en cuenta que la gran mayoría de tratados suscritos por Prusia entre los diversos actores, era de índole bilateral, razón por lo cual se precisaron cerca de casi 4 años (1831-1835) en el transcurso de los cuales los prusianos multiplicaron las concesiones de detalle, pero continuaron firmes en el principio del proteccionismo moderado con respecto al extranjero. Firmándose con 25 Estados (lo cual significo uniformizar un mercado de cerca de 26 millones de habitantes) los que unificaron sus sistemas aduaneros respecto al exterior y lo abolieron en sus relaciones recíprocas con los demás estados germánicos. Quedaron fuera de esta unión: Hannover, Oldenburg y las ciudades hanseáticas (Ayçoberry, 1988, p. $48)$.

No obstante, a pesar de haberse superado las barreras arancelarias dentro de la Zollverein, todavía no se puede hablar de un mercado común eficiente, debido al coste de los transportes:

En concreto, todavía no existía a mediados de siglo un mercado verdaderamente único. La razón es evidente: el coste de los transportes anula todavía, y a partir de una cierta distancia, las ventajas de una industria modernizada, sobre todo para los productos de gran consumo (Ayçoberry, 1988, p. 53).

Por ello, frente a esta situación, es que se comienza a desarrollar la industria ferroviaria, la cual no solo propicia un aumento de la demanda de mano de obra directa para la construcción de líneas férreas o la creación de los mismos trenes, sino que abarata los fletes de transportes de las mercaderías y propicia las condiciones de infraestructura necesarias para sacar el mayor provecho posible al Zollverein y de esa forma dar paso a un verdadero mercado común entre los Estados miembros.

No es hasta después de 1845 que, gracias a las asociaciones financieras interregionales y a los estímulos de ciertos estados, que Berlín queda unido con 
Sajonia, con Hamburgo, con Renania vía Hannover, y que se empieza a duplicar el Rhin con algunos ramales de vía férrea: el nuevo medio de transporte ya no duda en competir con el antiguo. En total $2.500 \mathrm{~km}$ de líneas férreas (...) (Ayçoberry, 1988, p. 54).

\subsubsection{El parlamento de Frankfurt, primer intento fallido a la unificación.}

Nuevamente Francia, para los años 1848 va ser un elemento que contribuye y fomente el espíritu de unidad y eventual integración de los Estados germánicos, ello como consecuencia de la II República Francesa y el II Imperio Francés.

El año 1845 significó para Francia el inicio de una crisis económica muy fuerte: malas cosechas, disminución de los ingresos de las arcas públicas, cierre de fábricas, aumento del desempleo y el hambre generalizado. La pequeña burguesía y los estudiantes se unieron a las protestas de los obreros, de manera que cuando el Gobierno intentó utilizar la fuerza pública para restablecer el orden, esta se rehusó y obligó al rey Luis Felipe de Orleans a abdicar. De esta manera, se creó un Gobierno provisional, que daría paso a la Segunda República Francesa.

Hecho que no pasó desapercibido por toda Alemania, "la noticia de la revolución parisina es la chispa que enciende casi todas las regiones de Alemania, pero se trata unas veces de humo de paja y otras veces de incendios de muchas más graves consecuencias" (Ayçoberry, 1988, p. 72).

No obstante, los acontecimientos franceses repercuten también en la Confederación Germánica, en colonia el 3 de marzo de 1848 los miembros de la Liga de los Comunistas hacen que millares de persona aclamen un programa radical de instrucción gratuita y de protección del trabajo, sin que la propiedad privada sea todavía directamente cuestionada (Ayçoberry, 1988, p. 73). 
Básicamente estas olas de protestas tenían como finalidad cambiar a un modelo de corte más liberal, acabar buscando eliminar derechos feudales buscando de esta forma que las ideas que motivaban las protestas francesas se repliquen en los Estados Germánicos.

A partir del 2 de abril de 1848, las presiones populares en Prusia hacen que la Dieta unida adopte un proyecto de Asamblea Nacional elegida por sufragio universal, pero mediante escrutinio indirecto (de esta forma también se daba gusto a los moderados). Téngase presente que parte de estos conflictos ya habían tenido un enorme costo en Viena, donde el Canciller Metternich fue expulsado y se había obtenido la promesa de una asamblea constituyente, como se observa el fenómeno revolucionario francés se estaba replicando en Alemania (Ayçoberry, 1988, pp. 73-74).

No solamente el cambio de espectro político al liberalismo, sino la amenaza que significaba la proclamación de la II República Francesa liderada por el sobrino de Napoleón Bonaparte y el miedo a que vuelva a barrer Europa igual que la I, generan una movilización general en donde se comienzan a sentar las bases para la convocatoria a lo que sería conocido como el Parlamento de Frankfurt de 1848.

En la mayoría de Estados alemanes se habían constituido los "Märzregierungen" denominados "gobiernos de marzo", los cuales eran de línea liberal. El 10 de marzo de 1848, el parlamento nombró un Siebzehnerausschuss ("comité de los diecisiete") para preparar una constitución; el 20 de marzo, el Bundestag exhortó a los Estados miembros de la confederación a convocar elecciones para una asamblea constituyente; sin embargo, y tras graves altercados callejeros en Prusia, también este convocó a una Asamblea Nacional, para preparar la constitución del referido reino. (Clark, 2006)

Los 831 diputados elegidos en todo el territorio de la Confederación Germánica se reunieron con el consentimiento del rey prusiano Federico Guillermo IV de Prusia en la iglesia de San Pablo, en Fráncfort del Meno. Las sesiones se desarrollaron entre el 18 de mayo de 1848 y el 31 de mayo de 1849. (Clark, 2006)

Esta Asamblea produjeron la redacción de la primera constitución alemana, la Constitución de Fráncfort de 1849 (Verfassung des Deutschen Reiches, llamada también 
Paulskirchenverfassung, o constitución de la iglesia de San Pablo), que no llegó a entrar en vigor. (Clark, 2006)

Una vez culminado el proyecto de constitución, los diputados ofrecieron la corona de Alemania a Federico Guillermo. El cual no la aceptó y provocó que los diputados prusianos y austriacos abandonaran el parlamento, que estaba condenado a ser disuelto. (Clark, 2006)

Este fracaso de primer intento de unidad terminaría en los siguientes términos:

Los gobiernos se rebelan unos después de otros contra los parlamentos y sus obras. Cuando la asamblea prusiana censura la actitud del rey, es disuelta el 27 de abril de 1849; un mes más tarde, será abolido el sufragio universal en el reino y sustituido por el sistema llamado "de las tres clases", que favorece a los grandes contribuyentes: la monarquía tiende decididamente la mano a los ricos. En Sajonia, el rey rechaza también la constitución y disuelve las Cámaras: la simultaneidad de estas dos medidas acaba convenciendo a los demócratas que su causa está vinculada con la del Parlamento de Frankfurt. (Ayçoberry, 1988, p. 87)

\subsubsection{Consolidación de la Zollverein y pérdida de influencia austriaca dentro de la Confederación Germánica.}

El fracaso a este primer intento de unificación tiene sus causas principalmente en los origines liberales, las ideas propias de la revolución francesa, así como en la incapacidad de los demócratas para organizarse y poder estructurar una unificación que de alguna forma recoja y represente los valores y principios propios del pueblo alemán, así como su tradición política y no solamente el deseo o anhelo de una Alemania.

No obstante, y a pesar de este fracaso, el proceso de integración económica a través de la Zollverein continuó con éxito, para 1851 se amplió con la incorporación de Hannover y Oldenburg, después de negociaciones llevadas a cabo directamente con Berlín y sin consultar a los otros miembros; para Prusia, es la desaparición de una frontera molesta y también el acceso al mar del Norte. (Ayçoberry, 1988, p. 90) 
Pero la Unión Aduanera demuestra sobre todo su solidez frente a los bruscos y violentos ataques austriacos. La lucha, que dura diez años, ya no es simplemente entre una economía moderna u una economía retrasada, apoyada por el poder imperial.

En noviembre de 1851 propone una unión aduanera fuertemente proteccionista; si Prusia la rechaza se romperá el Zollverein. Ahora bien, Prusia aguanta el envite y amenaza con no renovar el tratado de 1834, que justamente acaba de vencer, y los estados del sur abandonan a Austria que debe contenerse con un tratado comercial. ¿Por qué esta capitulación? Porque los círculos económicos del sur, después de comprar los pros y los contras, descubren que su solidaridad es mayor con Berlín, Renania y Silesia que con la Europa Central. Esto en gran medida al gran trabajo que Otto von Bismarck desarrolló desde su puesto de embajador en la Dieta de Frankfurt influenciando a la prensa denunciando las debilidades de la economía y las finanzas austriacas. (Ayçoberry, 1988, p. 90)

Es entonces cuando Prusia decide a su vez cambiar el espíritu del Zollverein, llevándolo de una zona de libre comercio entre sus estados, a una unión aduanera el establecer con Francia en 1862 un tratado que extremadamente liberal, abandonando el semi-proteccionismo típico imperante desde 1818.

Para Austria este hecho es la ocasión de volver a poner en práctica su gran proyecto de liderar la Zollverein, surgiendo nuevamente la posibilidad de una fractura al interior de la zona de libre comercio. Durante aproximadamente dos años y medios este tratado con Francia generó furor, no obstante Bismarck - quien entretanto había tomado en sus manos la dirección política de Prusia- estaba seguro de su obra: en todas partes los gremios de congresos de economistas, gremios de industriales y negociantes se pronunciaban a por el mantenimiento de la Zollverein en las condiciones establecidas ahora por Prusia. Esto en gran parte a que dichos gremios habían perdido el complejo de inferioridad e inseguridad al comercializar sus productos, convencidos de la calidad de los mismos y de ser buenos competidores frente a otras potencias industriales tales como Francia, Inglaterra o Bélgica o incluso, considerar a estos últimos como potenciales colaboradores. Por ello para 1864, frente a la posición de los gremios empresariales y economistas, a los demás estados germánicos que no hubieran estado del todo de acuerdo, solo les quedaba incorporarse a las pretensiones prusianas. De esta manera, las pretensiones austriacas fueron nuevamente 
aplastadas debido a la astucia y gran manejo de Bismarck, en lo que a política económica y comercial respecta, quedando Austria definitivamente fuera de lo que sería Alemania y dando paso a futuros enfrentamientos en el campo militar. (Ayçoberry, 1988, p. 91)

A partir de este momento ya se puede hablar de mercado único ${ }^{78 .}$ Los precios se van acercando entre el este y el oeste. Y aparece una nueva división del trabajo entre los diferentes medios de transporte: a los ríos y los canales las materias pesadas, al ferrocarril los viajes y las mercancías más ligeras. Los intercambios se simplifican yendo directamente del vendedor al comprador, y las ciudades intermedias y las ferias pierden su importancia. Finalmente, la industria se concentra en las regiones más favorables: es así como se va perfilando el mapa de la Alemania moderna. (Ayçoberry, 1988, pp. 91-92)

\subsection{Otto von Bismarck y el proceso de unificación alemana (1862-1871)}

Cuando se habla de la unificación alemana, dos actores resaltan a toda luz: Prusia, como motor de unidad y unificación y Otto von Bismarck como cerebro y conductor político de dicho proceso.

Otto von Bismarck nació el 1 de abril de 1815, en Magdeburgo, Alemania. Fue un destacado político Canciller de Prusia, más conocido como el "Canciller de Hierro", teniendo un rol preponderante en el proceso de la unificación alemana y uno de los líderes más brillantes en lo que a política internacional respecta de la segunda mitad del siglo XIX.

En 1847, fue electo como parlamentario del reino de Prusia, donde muy pronto se convirtió en líder del ala conservadora. Fue en su experiencia parlamentaria, donde demostró su gran talento como político desde joven, enfrentando duramente a la revolución de 1848 que sacudió su nación. (Voltes, Bismarck, 2004)

78 O lo que se define como Mercado Común. 
Tras el triunfo conservador y la supremacía de Prusia frente a los demás Estados germanos, este comenzó a planificar su obra maestra: la unificación de Alemania y la creación del Segundo Reich. (Ramos-Oliveira, 1973)

Tras varios años de participación en la política, fue nombrado Canciller de Prusia en 1862 y emprendió una reforma militar que le permitió disponer de un poderoso ejército para llevar a cabo sus planes de unificación alemana. No obstante, y previo a este tipo de reformas militares, introdujo notables reformas en las condiciones laborales de Prusia: la rebaja en las horas de trabajo, aumentos de salario así como un programa de jubilaciones, pensiones y atención pública que pasaría a la historia como el "Estado de Bienestar". (Ayçoberry, 1988)

Cerrando el frente interno de la política con los trabajadores y las familias conformes y contenidas, se pasó a atender las necesidades del frente externo: buscar la tan ansiada unificación alemana bajo la hegemonía de Prusia. Desde 1862, Bismarck presentó su plan a varios asesores militares: el mismo consistía en que Alemania debía neutralizar necesariamente a Austria y alinearse a todos los estados germanos consigo mismo, aunque esto implicaba renunciar al sueño de una "Gran Alemania" con Austria. Pero, ¿Por qué apartar y neutralizar a Austria de este proceso? La respuesta se encuentra en la teoría previamente desarrollada en esta investigación de la Gravitación de los Estados. (Ayçoberry, 1988)

Como ya se desarrolló anteriormente, los Estados grandes o poderosos generan una fuerza de influencia similar a la gravedad, haciendo que Estados más pequeños giren en torno a este y finalmente actúen acorde con la influencia del primero, pero si encontramos dos Estados grandes e igualmente poderosos, que a su vez están compuestos por los mismos elementos espirituales que todo pueblo tiene (idioma, cultura, religión ${ }^{79}$, entro otros), se va encontrar un proceso de integración con una enorme dificultad por consolidarse, puesto que la fuerza que genere la atracción para uno u otro, será anulada o resistida por la fuerza de la contra parte; por ello, la necesidad de retirar a Austria del presente proceso de integración, más aún

\footnotetext{
${ }^{79}$ En el caso de los pueblos germánicos, la gran mayoría eran de corte protestante - luterano, salvo por el sur que era católico, junto con Austria. No obstante, y a pesar de esa diferencia, en el fondo lo que terminaba por unir el elemento religioso era que, por encima de católicos o protestantes, eran cristianos, compartiendo una moral o visión muy similar entre sí.
} 
porque el imperio austriaco, a diferencia de Prusia y de los demás Estados Germánicos, tenía una peculiaridad que terminaba siendo una desventaja en esta disputa por la hegemonía en la unidad alemana, era un reino pluricultural, donde no solo estaba compuesto por pueblos germánicos de habla alemán, sino por húngaros, eslavos, entre otros. Esta pluralidad cultural dificultaba la idea de una unidad germana total con Austria por la sencilla razón de no ser puramente germánico, sino un crisol de culturas y naciones (von Bismarck, 1898).

El segundo punto era que para posicionarse como un actor internacional de peso, era necesario chocar con otro coloso su época, que sin dudas era Francia, gobernada por Napoleón III, sobrino del emperador Napoleón Bonaparte. De esta forma, en 1864 el ejército prusiano consiguió arrebatar a Dinamarca los ducados de Lauenburgo, Schleswig y Holstein y, dos años más tarde, después de luchar contra Austria (antigua aliada de Prusia), consiguió la anexión de las ciudades de Hesse, Fráncfort, Hannover y Nassau, poniendo de rodillas a los austriacos. En 1870 enfrentó la guerra final contra Francia, siendo el primer choque con una enorme potencia de la época, donde Prusia salió victoria y producto de eso se transformó en el Segundo Imperio Alemán con Bismarck como canciller. (Clark, 2006)

Por su dureza contra opositores políticos desde la época como parlamentario y luego como Canciller, obtuvo el sobrenombre de "Canciller de Hierro", así como ganarse con justo derecho la imagen de ser el hombre más acorde para liderar el proceso de consolidación de la integración germana. Por otra parte, en otras esferas del plano internacional, no solo el nacimiento del II Reich fue su gran acierto, la creación de la Triple Alianza junto a Italia y Austria-Hungría, para aislar a Francia; así como al Congreso de Berlín que aseguró el reparto de África, y posterior obtención de colonias para darle un mayor peso geopolítico en el escenario internacional a Alemania ${ }^{80}$ (von Bismarck, 1898).

\footnotetext{
${ }^{80}$ Es oportuno recordar que, en aquellos tiempos, la grandeza de un Estados se medía por su grandeza territorial, una potencia europea necesitaba contar con colonias, más aún para sostener el proceso de la revolución industrial, el cual venía por desarrollarse paralelamente con el Congreso de Berlín.
} 


\subsubsection{La Guerra de los Ducados, la derrota de Austria y la hegemonía prusiana en la Confederación (1866)}

La Guerra de los Ducados fue un conflicto militar que enfrentó al Imperio austríaco y Prusia contra Dinamarca en 1864. Los precedentes a este conflicto se encuentran en 1863, cuando el monarca danés, Cristián IX, intentó incorporar a Dinamarca el ducado de Schleswig- Holstein, que se encontraba bajo el control oficial de los alemanes, generando de esa forma la protesta de la Confederación Germánica (Clark, 2006).

El Protocolo de Londres de 1852, dispuso que Schleswig quedara unido al ducado de Holstein, que era miembro de la Confederación Germánica. El canciller Bismarck logró convencer al emperador de Austria para que firmaran un acuerdo (16 de enero de 1864) y juntos defendieran el referido protocolo. Tras ello, Bismarck lanzó un ultimátum a Dinamarca en el que exigía que la Constitución danesa promulgada en noviembre (1863) debía ser abolida en 48 horas, lo cual dio como respuesta el rechazo contundente del gobierno danés.

Es ese mismo año que el monarca danés muere sin dejar descendencia masculina. La costumbre danesa autorizaba la sucesión a las mujeres, pero no la de los ducados, razón por la cual los patriotas de dichos territorios buscaron utilizar la ocasión para obtener su autonomía (Ayçoberry, 1988, p. 110)

En una primera etapa, "deja hervir la sopa". La Dieta confederal se erige nuevamente en protectora de la nación y consigue incorporar a Augustenbug ${ }^{81}$ en el Holstein...pero no puede intervenir en el Schleswig que continúa al margen de su competencia. Por su lado, Prusia y Austria se declaran dispuestas a abandonar los ducados si Dinamarca les garantiza sus libertades tradicionales. En este momento toda Alemania explota en furor. Felizmente para Bismarck los daneses rechazan el compromiso, lo que desencadenara una guerra de seis semanas (marzoabril 1864) en la que el ejército prusiano, reorganizado, hace sus primeras armas ayudado por los austríacos, muy molestos de encontrarse ahí (Ayçoberry, 1988, p. 110).

${ }^{81}$ Duque de Augustenburg 


\section{Seguidamente,}

En una tercera etapa (finales de abril-finales de junio) es preciso negociar con las grandes potencias: pero Bismarck multiplica las promesas a Francia y Rusia, juega con la lasitud de Inglaterra, y aísla a Dnimarca. Ya tiene pues las manos libres para una segunda campaña militar, que solamente dura algunos días. Estas victorias empiezan a hacer que la opinión nacional se vuelva favorable a Prusia: ya Droysen y Treitschke evocan con palabras encubiertas que la anexión de los ducados es como un preludio a la unificación total de Alemania; en nombre del realismo, explican que, en ciertos casos, el ciudadano debe sacrificar sus principios a la grandeza del estado, en pocas palabras, prepara ya la incorporación (Ayçoberry, 1988, pp. 110-111).

No obstante, solo faltaría convencer a Austria que hasta ese momento había seguido a Bismarck "como su negro", de que ceda los ducados a Prusia, es decir, a fin de cuentas, traicionar a la Confederación germánica. (Ayçoberry, 1988, p. 111).

Los ducados abandonados por Dinamarca en la paz de Viena del $1^{\circ}$ de agosto de 1864, son primeramente entregados conjuntamente a las dos potencias victoriosas y no a la confederación: primera traición. A continuación, las autoridades prusianas de ocupación multiplican las provocaciones, rechazan el reconocimiento del duque de Augustenbrug, hasta el punto de que, para evitar lo peor, Austria se resigna a compartir el botín (Convención de Gastein, agosto 1865): Schleswig para Prusia y Holstein para sí misma; con ello pierde las últimas simpatías con los defensores del Derecho y de la Legitimidad, sin ganar gran cosa: ¿qué va a hacer tan lejos hacia el norte? Es significativo que la principal asociación de la propaganda para la Gran Alemania, la Reformverein, se disolviera con las noticias de Gastein. Todo el mundo estima que la partición es solo provisional y que se espera una guerra. (Ayçoberry, 1988, p. 111)

La eficacia prusiana en este conflicto resultó clara, hecho que contribuyó a que la percepción de los Estados alemanes considere a Prusia como el único capaz de defender a los demás ante una posible agresión de una potencia extranjera.

Prusia y Austria se hicieron cargo de la administración respectiva de Schleswig y Holstein bajo la Convención de Gastein del 14 de agosto de 1865. Asimismo, la paz de Praga de 1866 
confirmó la cesión de Dinamarca de los dos ducados en favor de las potencias germánicas antes mencionadas, pero prometía un plebiscito para decidir si el norte de Schleswig regresaba al gobierno danés. Esta disposición se estableció unilateralmente por una resolución de Prusia y Austria en 1878 (Clark, 2006).

No obstante, Bismarck saboteó deliberadamente la administración austriaca de Holstein, mandando tropas a ese ducado cuando Austria protestó ante el Parlamento de Fráncfort, una vez asegurada la neutralidad del Imperio ruso - el cual se encontraba todavía resentido por la neutralidad de Austria durante la guerra de Crimea - y contando con su alianza con el reino de Italia. Cuando Austria protestó ante la Dieta de Fráncfort (asamblea de la Confederación), Baviera, Hannover, Hesse-Kassel, Sajonia, Wurtemberg y otros Estados apoyaron a Austria (von Bismarck, 1898). Esta situación terminaría desencadenando en la guerra de las Siete Semanas entre las dos potencias germanas. (Clark, 2006).

En octubre de 1865, Otto von Bismarck, canciller prusiano, obtuvo de Napoleón III que Francia se mantuviera al margen ante un eventual conflicto austro-prusiano, mientras que Prusia se comprometió a apoyar al Reino de Italia (el cual se encontraba inmerso en su proceso de consolidación como un Estado unitario) para conseguir la anexión del Véneto. Napoleón III consideró que el conflicto sería largo, brindándole la oportunidad de actuar de mediador y de esa manera, tentar la posibilidad de conseguir ventajas territoriales, esperando en todo caso un fracaso militar de Prusia. (von Bismarck, 1898)

Prusia tenía como ventaja una organización militar superior, donde las guarniciones estaban distribuidas por distritos, los cuales facilitaban la conscripción de hombres en edad militar residentes allí, evitando así los largos desplazamientos de reclutas; por otro lado, el entrenamiento de los estos duraba tres años, lo que permitía contar con tropas mejor preparadas y disponibles en mayor número (Clark, 2006).

Por el contrario, Austria tenía la política de distribuir tropas en regiones extrañas a sus conscriptos, ello porque a diferencia de Prusia, Austria era un reino compuesto por varias naciones, de esa forma al distribuir tropas por regiones diferentes a su lugar de origen, se lograba evitar revueltas de corte nacionalistas que pudieran mermar la unidad del imperio; como resultado, sus reclutas no estaban adscritos a las guarniciones de su localidad, y debían 
recorrer grandes distancias para enrolarse. Asimismo, el ejército austriaco no mantenía por mucho tiempo enrollada a sus tropas, lo cual hacía que una movilización bélica requiriese entrenar nuevas en poco tiempo (Clark, 2006).

Una ventaja que sí poseía Austria con relación a Prusia, era que tenían mejores tropas de caballería pesada; sin embargo, éstas habían perdido gran parte de su importancia desde las Guerras napoleónicas, en gran medida por el desarrollo y uso de los cañones y fusiles, reduciendo la relevancia en el campo de batalla por parte de la caballería pesada. En lo que artillería respecta, no había ventajas entre una y otra fuerza, pero la lentitud de la concentración de tropas por parte de Austria anulaba rápidamente toda ventaja que esta pudiera tener. Por otro lado, la infantería prusiana poseía mayores efectivos y gozaban de un mejor entrenamiento que la austriaca y disponía una mejor tecnología en lo que armas (fusiles) respecta. (Clark, 2006).

Otra ventaja clave en lo que tecnología e infraestructura poseía Prusia, era su sistema de ferrocarriles, el cual era el más avanzado de Europa, con cinco grandes líneas férreas que entrecruzaban su territorio y permitían rapidez en el transporte de tropas. Esta ventaja le permitió organizar sus fuerzas para la campaña contra Austria en apenas veinticinco días, reuniendo oportunamente sus batallones para dirigirlos a la frontera austriaca. Por otra parte, Austria apenas tenía una gran línea de ferrocarril, que no llegaba a las regiones fronterizas con Prusia, lo cual generaba que la gran parte del trayecto de sus tropas se tuviera que realizar a caballo o a pie, demorando notablemente en movilizar y organizar al grueso de sus fuerzas (Clark, 2006; Ayçoberry, 1988).

Austria declaró la guerra al Reino de Prusia el 14 de junio de 1866, lo cual dio como respuesta que el ejército prusiano movilizara sus fuerzas a la región de Silesia para atacar territorio austriaco, invadiendo Bohemia y el Reino de Sajonia de manera veloz y repentina, sin dar tiempo a que las tropas austriacas pudieran intervenir en defensa de sus aliados. En esta guerra el uso del telégrafo fue muy extendido entre ambos contendientes, lo cual permitía la llegada de órdenes militares de forma rápida y fluida. (Clark, 2006)

No obstante, el avance prusiano fue detenido brevemente por tropas austriacas en la batalla de Trútnov del 27 de junio, sufriendo un gran número bajas, mientras que un exitoso 
contraataque austriaco en Jičín, del 29 de junio, no afectó significativamente a los prusianos. El ejército prusiano siguió avanzando por el norte de Bohemia reuniendo cada vez más tropas, mientras que Austria atravesaba serias dificultades para concentrar sus fuerzas oportunamente (Ramos-Oliveira, 1973).

En paralelo, Prusia atacó el territorio del Reino de Hanover y avanzó hasta ser detenida por las tropas de dicho reino en la batalla de Langensalza el 27 de junio. Si bien las tropas hannoverianas vencieron en esa ocasión a las fuerzas prusianas, el combate dio tiempo a que otros cuerpos del ejército prusiano avanzaran hacia las posiciones del ejército hannoverianos, forzando a que éstos se replegaran a las montañas Harz al día siguiente. Ante la superioridad numérica prusiana, el Reino de Hanover finalmente se rindió el 29 de junio, quedándose Austria sin su único gran aliado en el norte, lo cual permitió a las fuerzas prusianas transitar libremente de un extremo a otro de su territorio (Clark, 2006).

Es oportuno acotar que el ataque prusiano a Hannover no solo se dio por el hecho de ser un aliado de peso de Austria, sino como una forma de querer "imponer" su hegemonía en el norte alemán, dado que este reino, Hannover, estaba emparentado y vinculado estrechamente a la corona inglesa, enemigo prusiano no solo en materia económica sino geopolítico, por ello, el anexar a Hannover, significaba desde una visión geopolítica no solo cortar con la influencia inglesa que afectaba la total integración hannoveriana con los demás Estados germánicos, sino hacer que finalmente este importante reino gire en torno a la influencia del núcleo de integración germánico, Prusia, y de esta forma hacer más sólido el proceso de integración alemana.

Para fines de junio, las tropas prusianas atacaron Baviera (aliado austriaco) y en una rápida campaña tomaron Núremberg y Fráncfort del Meno. Luego las tropas bávaras opusieron severa resistencia en las fortificaciones de Wurzburgo hasta el fin de la guerra, pero sin poder expulsar a los prusianos del resto de su territorio (Clark, 2006).

El avance prusiano sobre territorio austriaco continuó en el norte de Bohemia. El ejército prusiano logró derrotar decisivamente al ejército austriaco el 3 de julio en la batalla de Sadowa gracias a la maniobra del general Helmuth von Moltke que agrupó a tiempo a sus tres grandes masas de tropas, sorprendiendo a los austriacos y causándoles severas pérdidas 
(cinco bajas austriacas por una prusiana). Austria había reunido para esa batalla cerca de 184.000 hombres, con apoyo de 22.000 soldados de Sajonia, mientras que Prusia empleó 224.000 hombres, de modo que la diferencia numérica entre ambas fuerzas en combate no era muy grande (Clark, 2006).

La movilidad de las tropas prusianas, gracias a la red ferroviaria, resultó un factor clave para obtener la victoria. Tras esta victoria, las tropas prusianas avanzaron hacia el sur y entraron a Eslovaquia el 19 de julio, sin gran oposición y el 22 de julio se enfrentaron a los austriacos en las cercanías de Presburgo, en la batalla de Lámacs, obteniendo otra victoria. Ese mismo día Austria solicitó un armisticio a Prusia (Clark, 2006; Ayçoberry, 1988). Ello puso en evidencia que un ejército no solo se erige sobre las armas o número de efectivos, sino básicamente sobre la logística sostenida en la infraestructura del Estado para poder movilizar tropas, suministros y refuerzos en el combate.

\subsubsection{La Confederación Alemana del Norte}

El 23 de agosto de 1866, con la Paz de Praga quedó disuelta la Confederación Germánica. Prusia se anexó Hannover y Hesse-Kassel; Austria cedió Holstein a Prusia, pagó indemnización de guerra y entregó el Véneto al Reino de Italia al firmar la Paz de Praga. Prusia constituyó la Confederación Alemana del Norte. (Clark, 2006; Ayçoberry, 1988)

De esta forma, Prusia se convirtió en la potencia hegemónica en Alemania y pudo establecer la unión de los Estados alemanes situados al norte del río Meno. Esta alianza reemplazó a la Confederación Germánica, siendo 22 los Estados alemanes que se incorporaron a la Confederación de Alemania del Norte. El poder legislativo ${ }^{82}$ quedó repartido en dos asambleas: el Reichstag (parlamento) y el Bundesrat (Consejo Federal) (Clark, 2006).

\footnotetext{
${ }^{82}$ Los Estados estaban representados en el Bundesrat (Congreso Federal) con 43 escaños (de los cuales 17 eran prusianos). Para las elecciones al Reichstag, Bismarck introdujo en Alemania el sufragio masculino. El Bundesrat se convirtió en el Parlamento del Zollverein en 1867, intentando crear una cercanía mayor con los Estados meridionales, permitiéndoles enviar representantes al Bundesrat. (Clark, 2006)
} 
La Confederación estableció alianzas con Baviera, Wurtemberg y el gran ducado de Baden, que se comprometieron a poner sus tropas bajo el mando del rey de Prusia si un tercer Estado atacara a algún miembro de la Confederación ${ }^{83}$. La Dieta fue elegida mediante sufragio universal, la nueva Constitución entró en vigor el 1 de julio de 1867 y Bismarck se convirtió en canciller de la nueva Confederación (Clark, 2006).

La Constitución contemplaba que cada Estado sería autónomo en materia de finanzas, justicia, culto ${ }^{84}$ y enseñanza. A la Confederación le incumbían ejército, marina, política exterior, legislación comercial, aduanas, moneda, legislación civil y correos. El poder ejecutivo estaba en la presidencia desempeñada por el rey de Prusia (con carácter hereditario), que era el responsable de la política exterior, comandante supremo del ejército y que ejercía el poder a través del canciller, que sólo respondía ante él (Clark, 2006).

Esto fue posible en gran medida por los avances en materia de integración que ya había alcanzado su antecesora la Confederación Germánica; tras el triunfo y consolidación de Prusia en la guerra austro-prusiana, este había absorbido o desplazado a otros Estados que eran una amenaza a su hegemonía (Hannover, Austria) dentro del marco de la otrora Confederación; de esta forma, la influencia política ya no estaba disputada o compartida con otros actores, no habiendo obstáculo alguno para que la visión de integración que tenía Prusia diera un paso más allá constituyendo el primer gran Estado Germánico de la era moderna, siendo Prusia el núcleo y centro del poder no sólo económico, sino político.

En Austria las consecuencias de la derrota fueron un debilitamiento del Estado frente a los movimientos nacionalistas de los distintos pueblos que formaban el Imperio, en especial de los húngaros que ya habían protagonizado diversas revoluciones contra el centralismo de los Habsburgo. Esto llevó a la formalización política del Compromiso Austrohúngaro por lo que el país se transformaba en una monarquía dual con dos Estados confederados bajo la casa de Habsburgo, el Imperio austrohúngaro que existiría desde 1867 hasta 1918 con la derrota en la Primera Guerra Mundial (Clark, 2006).

\footnotetext{
${ }^{83}$ Esto sería de vital importancia al momento que se inicien las hostilidades en la guerra Franco-Prusiana.

${ }^{84}$ Este punto es importante, porque si bien la gran mayoría de Estados germánicos eran protestantes, el sur siempre fue de mayoría católica, al no abarcar el culto como materia de competencia del nuevo Estado, se estaba dejando la puerta abierta para poder incorporar a otros territorios alemanes que profesaran una fe distinta a la mayoría, sin que el tema del culto pudiera ser un obstáculo a tener en cuenta.
} 


\subsubsection{La Guerra Franco-Prusiana (1870-1871): La culminación del proceso de integración alemán y el surgimiento del II Reich}

La guerra franco-prusiana fue un conflicto bélico que se libró entre el 19 de julio de 1870 al 10 de mayo de 1871 entre el Segundo Imperio francés (y después de la caída del régimen, por la tercera República francesa) y el Reino de Prusia, con el apoyo de la Confederación de Alemania del Norte y los reinos aliados de Baden, Baviera y Württemberg. El conflicto marcó el estallido de la tensión entre las dos potencias, que se acrecentó tras el fracaso del proyecto de Napoleón III de anexar Luxemburgo, un evento que causó el final de una relación relativamente equilibrada con la Prusia de Otto von Bismarck (von Bismarck, 1898; Clark, 2006).

La causa fundamental de la guerra fue la ruptura del equilibrio de poder que se había establecido en Europa tras el Congreso de Viena de 1815, luego del rotundo éxito obtenido por Prusia en la guerra contra Austria. Sucedió que al final de la guerra, después de la decisiva victoria de Sadowa, Bismarck se apresuró a extender el control prusiano a la mayor parte del norte de Alemania, incluyendo el territorio de Schleswig-Holstein, Hannover, Hesse-Kassel, Nassau, y la ciudad de Frankfurt. Berlín estuvo a punto de conseguir el dominio de Sajonia, Hesse-Darmstadt, Mecklemburgo, los ducados de Turingia y las ciudades libres de Hamburgo, Lübeck y Bremen, bajo la influencia de Prusia en la Confederación Alemana del Norte. De hecho, si no estalló inmediatamente la guerra fue únicamente porque Bismarck deseaba hacer crecer el sentimiento nacional alemán y Napoleón III necesitaba tiempo para completar la reforma modernizadora en el ejército (Clark, 2006).

Por otra parte, en Berlín ya habían estudiado y explotado todos los fiascos de política exterior cometidos por Napoleón III, el cual había fracaso en casi todas sus tentativas de halagar la moral del pueblo francés (intento fallido de la invasión a México, la intervención francesa en Italia que no había logrado contentar a los ultramontanos ni a los republicanos ni dado ventaja alguna al país (Voltes, 2004, p. 136). 
Ante esta serie de desaciertos, Francia pretendió por varios años incorporar Bélgica, hecho que fue utilizado por Bismarck para poder distraer y alargar las negociaciones por casi más de 5 años en los que logró finalmente convencer a Napoleón III que pretenda Luxemburgo (Voltes, 2004, p. 136).

Francia por su parte,

Ofreció a Prusia no oponerse a la unión de Alemania del Norte con la del Sur bajo la hegemonía de esta, si esta le facilitaba la adquisición de Luxemburgo. Para apoyar esta pretensión hizo el emperador emplear a todos los periódicos un lenguaje belicoso contra Prusia, lo cual dio lugar a que Bismarck descubriera, gracias a diversas indiscreciones de gacetilleros, que algunos estados meridionales de Alemania habían contraído en secreto alianzas ofensivas y defensivas con Francia. El mismo canciller declaró ante el Reichstag: "Si Francia hubiera movilizado, uniendo su ejército con los estados meridionales de Alemania, aliados de Austria, nos habríamos visto obligados a evacuar Bohemia para defender nuestras fronteras occidentales (Voltes, 2004, p. 136).

Asimismo, Bismarck,

Con respecto a Bélgica, se había mostrado singularmente dadivoso de palabra, y quiso también ser liberal con el tema de Luxemburgo. Para empezar, decidió que el derecho que Prusia tenía de mantener una guarnición en Luxemburgo quedaba derogado y así halagó y entretuvo a Napoleón III un tiempo. (Voltes, 2004, p. 136)

Durante 1868 hubo una crisis más aguda, ese año, Bismarck intentó construir una nueva unión aduanera con el sur de Alemania (después de haber perdido el Zollverein, luego reformado sustancialmente), a través del establecimiento de un Zollparlament (parlamento de aduanas en alemán); sin embargo, esta acción fue interpretada como un nuevo desafío a al poderío francés en la región. (Clark, 2006)

Durante las negociaciones para el armisticio entre Prusia y Austria de 1866, Napoleón III se opuso enérgicamente a una unión de entre los Estados alemanes del sur y el reino de Prusia. 
Por tal motivo, el emperador francés ordenó la movilización del ejército en el verano, amenazando con iniciar una guerra si Bismarck pretendía anexar uno de los tres estados del sur de Alemania: Baviera, Wurtemberg y Baden. (Clark, 2006)

Como se aprecia, las relaciones entre Francia y Prusia de por sí eran tensas, si bien por un lado se negociaba en buenos términos la expansión de los territorios franceses, por otro lado, era mal visto por parte de Napoleón III una eventual expansión de la Confederación Alemana del Norte con los Estados del Sur, esto muestra la gran muñeca diplomática de Bismarck para alargar y dilatar lo máximo posible el enfrentamiento natural que tarde o temprano Francia y Prusia tendrían años posteriores.

El episodio que terminó por detonar finalmente las crecientes tensiones entre Francia y Prusia fue por la candidatura del príncipe Leopoldo de Hohenzollern-Sigmaringe ${ }^{85}$ al trono de España ${ }^{86}$, a propuesta del entonces presidente del Consejo de Ministros español, el general Juan Prim. Esta candidatura favorecía mucho a Prusia, que adquiría de tal modo una gran ventaja estratégica sobre Francia, puesto que "flanqueaba" por el sur a los franceses al poner un gobernante de su propia casa real. Por ese motivo, Napoleón III, presionado por la opinión pública, gestionó una serie de movidas diplomáticas, con el fin de impedir que Leopoldo se sentara en el trono español, logrando que el padre de éste, Carlos Antonio de Hohenzollern-Sigmaringen, renunciara públicamente en nombre de su hijo (Clark, 2006).

Sin embargo, el Estado francés consideró insuficiente la renuncia pública del padre de Leopoldo y ordenó desplazar al embajador M. Benedetti para que se reuniera con el rey de Prusia Guillermo I, para lograr una renuncia pública por escrito de Leopoldo a esta candidatura. Este encuentro daría pie al famoso incidente del telegrama de Ems,

El 13 de julio, Benedetti, siguiendo las instrucciones del emeperador, volvió a encontrarse con el rey Guillermo I en Ems, en una reunión informal, donde le presentó la petición. Guillermo rehusó amablemente el pedido francés, aunque eso no le impidió saludar al embajador al día siguiente. Después de dicho encuentro, el rey Guillermo informó por telegrama al Canciller Bismarck de lo sucedido, por medio de un funcionario diplomático

\footnotetext{
${ }^{85}$ Pariente directo del Rey y por ende emparentado con la casa real prusiana Hohenzollern

${ }^{86}$ Ello, como resultado de la deposición en el año 1868 de Isabel II de España.
} 
de nombre Abeken. El referido telegrama, que sería conocido años más tardes por los historiadores como el "telegrama de Ems", llegó la noche del 13 de julio al palacio de Wilhelmstrasse en Berlín, lugar donde cenaban Bismarck, Moltke y Von Roon. Al recibi dicha comunicación, Bismarck reescribió la referida comunicación y lo "condensó" de tal modo que transformó el encuentro en un emplazamiento y la respuesta del rey en una reacción que podía resultar insultante para Francia. Como consecuencia, Francia declaró la guerra a Prusia el 19 de julio de 1870 (Clark, 2006).

El telegrama decía lo siguiente:

Al canciller federal, conde Bismarck.

Su Majestad el Rey me escribe:

«M. Benedetti me interceptó en el paseo a fin de exigirme, insistiendo en forma inoportuna, que yo le autorizara a telegrafiar de inmediato a París, que me comprometería, de ahora en adelante, a abstenerme de dar mi aprobación para que se renueve la candidatura de los Hohenzollern. Rehusé hacer esto, la última vez con cierta severidad, informándole que no sería posible ni correcto asumir tales obligaciones (para siempre jamás). Naturalmente, le informé que no había recibido ninguna noticia aún y, ya que él había sido informado antes que yo por la vía de París y Madrid, él podía fácilmente entender por qué mi gobierno estaba otra vez fuera de la discusión.

Desde entonces, Su Majestad ha recibido noticias del príncipe (padre del candidato Hohenzollern al trono español). Su Majestad ya había informado al conde Benedetti que estaba esperando este mensaje; mas, en vista de la 
exigencia arriba mencionada y en consonancia con el consejo del conde Eulenburg y mío, decidió no recibir de nuevo al enviado francés, sino informarle a través de un ayudante, que Su Majestad había recibido, ahora, confirmación de las noticias que Benedetti ya había recibido de París y que él no tenía nada más que decir al embajador.

Su Majestad deja a juicio de Su Excelencia comunicar o no, de manera inmediata, a nuestros embajadores y a la prensa, la nueva exigencia de Benedetti y el rechazo de la misma (Snyder, 1958) ${ }^{87}$.

No obstante, y consciente de lo que su respuesta traería consigo, Bismarck "condensó" el extenso telegrama de la siguiente manera,

«Después de que los informes acerca de la renuncia del príncipe heredero de Hohenzollern fueran oficialmente transmitidos por el Gobierno Real de España al Gobierno Imperial de Francia, el embajador francés presentó ante Su Majestad el Rey, en Ems, la exigencia de autorizarle a telegrafiar a París que Su Majestad el Rey habría de comprometerse a abstenerse de dar su aprobación para que la candidatura de los Hohenzollern se renueve.

Su Majestad el Rey, por lo tanto, rechazó recibir de nuevo al enviado francés y le informó a través de su ayudante que Su Majestad no tenía nada más que decir al embajador» (Snyder, 1958) ${ }^{88}$.

Frente a esta respuesta, el 11 de julio de 1870, Francia declara la guerra a Prusia, ello porque a Francia le servía como un pretexto para generar un frente externo que acallase las quejas y reclamos por reformas que acontecían al interior del Imperio dado el descontento masivo frente al gobierno de corte autocrático impuesto por Napoleón III, así como una nueva

\footnotetext{
${ }^{87}$ La traducción es propia.

${ }^{88}$ La traducción es propia.
} 
oportunidad para superar el fracaso que la invasión a México significó para los intereses franceses.

Por otro lado, Bismarck había desplazar al imperio Austriaco de toda pretensión de liderar a los Estados germánicos, gracias al rotundo triunfo prusiano en la Guerra de las Siete Semanas, pero ahora ansiaba unir bajo el dominio de Prusia a los estados del sur de Alemania que aún mantenían su independencia y una relación más estrecha con Austria, ello en gran medida por ser católicos; en tal sentido, excitar el patriotismo ante una supuesta "agresión francesa" parecía el medio más sencillo y práctico con el cual Prusia podría aglutinar sobre su figura a todos los Estados alemanes y así generar una cercanía por parte de los estados sureños. Por ello, Bismarck quería que fuera Francia la que atacara primero para así no quedar como agresor y que aquello le facilitara las cosas puesto que podía levantar la bandera del nacionalismo alemán y hacer una causa común frente al enemigo externo.

De acuerdo con el plan de guerra formulada por el general Charles Auguste Frossard, tenía previsto desplegar una posición defensiva en el Rin esperando el ataque prusiano. Sin embargo, después de la visita del mariscal de campo austríaco Alberto de HabsburgoTeschen (un veterano de 1866 y con ganas de venganza contra los prusianos), Napoleón III modificó el plan de Frossard. Anticipándose a la entrada en la guerra de Austria-Hungría, los franceses, con sus fuerzas divididas en dos grupos, uno en una posición defensiva en Metz y el otro con la orden de ataque en Estrasburgo, debían proceder basándose en este último grupo en el Palatinado con el fin de separar a Prusia y "liberar" a los estados alemanes del sur (Clark, 2006).

Napoleón III organizó sus fuerzas en tres ejércitos: el ejército de Chalons bajo el mando de François Certain de Canrobert (VI Corps), el de Alsacia en Estrasburgo agrupado y guiado por el mariscal de Francia Patrice de Mac-Mahon (I Corps) yel ejército del Rin sujeto a su control. (Clark, 2006)

Por otra parte, el alto mando prusiano, bajo la dirección de von Moltke elaboró un plan de movilización basado en la descentralización de los trabajos previos, que estarían a cargo de los altos mandos en las distintas comandancias generales. 
De una manera diferente a Le Bœuf, von Moltke tenía un plan desde 1866. La clave del éxito militar de Moltke se debió a la introducción de dos nuevos elementos básicos en la estrategia bélica: la introducción del fusil de aguja, que triplicó la velocidad del disparo de la carabina tradicional y la utilización de la red de ferrocarriles y del telégrafo para asegurar el adecuado movimiento y transporte de las tropas. (Clark, 2006).

Por otro lado, el Estado Mayor francés planeó lo más rápido que pudiese iniciar operaciones en territorio alemán. No obstante, en los primeros días de agosto de 1870, el ejército francés comenzó a sufrir serios reveses. Batalla tras batalla, los franceses se veían forzados a introducirse cada vez más en su propio territorio. Tras unas pocas semanas, el ejército alemán llegó a luchar en pleno territorio enemigo (Clark, 2006).

Sin embargo, aunque las fuerzas alemanas tuvieron éxito ante el ejército francés, se constituyó una resistencia francesa a manos de partisanos tras las líneas de batalla que atacaban las rutas alemanas de abastecimiento, lo cual los hacía una fuerza bastante amenazadora e impredecible para las tropas alemanas (Clark, 2006).

La debacle y posterior derrota francesa y de Napoleón III se dio con La batalla de Sedán, la cual se libró entre el 1 y 2 de septiembre de 1870. El Ejército de Chalôns, con 202 batallones de infantería, 80 escuadrones de caballería y 564 cañones de artillería, atacó a al Tercer Ejército Prusiano y Ejército del Mosa, que comprendían 222 batallones de infantería, 186 escuadrones de caballería y 774 cañones. El general de Wimpffen, comandante del V Cuerpo Francés de reserva, esperaba poder lanzar un ataque combinado de infantería y caballería sobre el XI Cuerpo Prusiano. Sin embargo, hacia las 11:00 la artillería prusiana atacaba las posiciones francesas mientras llegaban nuevos refuerzos germanos al campo de batalla. Tras un intenso bombardeo, cargas prusianas desde el este y noroeste, y ataques bávaros desde el suroeste, el Ejército de Chalôns fue repelido hacia Bois de la Garenne, donde capituló. La caballería francesa, comandada por el general Marguerite, lanzó tres ataques desesperados en la cercana aldea de Floing, donde se había concentrado el XI Cuerpo Prusiano. Marguerite cayó en combate liderando la primera de estas cargas, y las dos siguientes no tuvieron más fruto que importantes pérdidas para los franceses. 
Ya para el final de la batalla, ya sin esperanzas de romper el asedio, Napoleón III ordenó un alto el fuego: 17.000 franceses habían muerto o caído heridos, y otros 21.000 habían sido capturados. Las pérdidas prusianas ascendían a 2.320 hombres muertos, 5.980 heridos y 700 capturados o desaparecidos.

Al día siguiente, 2 de septiembre de 1870, Napoleón III ordenó izar bandera blanca, rindiéndose con todo el Ejército de Chalôns a Moltke y al rey prusiano (Clark, 2006).

La rendición del emperador Napoleón III no puso fin a la guerra, pues cuando la noticia llegó a París, generó un levantamiento popular daría paso a la proclamación de la Tercera República y pondría fin al II Imperio Francés. Dicho levantamiento popular, nombraría un Gobierno de Defensa Nacional presidido por el general Louis Jules Trochu y del que formarían parte destacados personajes históricos de la talla de León Gambetta entre otros.

Tras la rendición de Napoleón III, Bismarck esperaba lograr una rendición rápida y total, al no haber una autoridad legítima con la que negociar (el emperador estaba prisionero, la emperatriz Eugenia de Montijo exiliada y el Gobierno así formado no tenía mandato electoral alguno), ordenó a sus tropas que sitiaran la capital francesa. Para el día 20 de septiembre, el cerco era una realidad (Clark, 2006).

Entretanto, el nuevo Gobierno de Defensa Nacional, que en un primer momento sí estaba dispuesto a una rendición a cambio de algunas colonias y reparaciones de guerra, tras tomar conocimiento de las durísimas condiciones que exigía el canciller germano para la rendición (entre las muchas exigencias encontramos la entrega de Alsacia, Lorena y diversas fortificaciones fronterizas), optó por continuar la guerra a toda costa, pero a pesar de sus proclamas de que no se cedería ni un centímetro de terreno, no consiguió ni siquiera reducir el ritmo del contundente avance alemán (Clark, 2006).

Ante las constantes derrotas sufridas por las nuevas tropas y los partisanos, y ante la dureza del sitio de París (que tuvo como consecuencia que muchos parisinos comenzaran a padecer de hambre) el Gobierno de Defensa Nacional aceptó (a pesar de la negativa de la población) negociar un armisticio en Versalles, por lo cual se envió al ministro de Asuntos Exteriores Jules Favre (Clark, 2006). 
Bismarck aceptó únicamente levantar el sitio a cambio de la entrega de varias fortalezas que eran claves en la defensa de París. El presidente Trochu dimitió y dos días después, el 25 de enero, Favre firmaba el armisticio.

Previamente, el 18 de enero de 1871, Guillermo I fue proclamado emperador (káiser) en la Galería de los Espejos del palacio de Versalles y con ello se completó la unificación alemana con la Constitución de 1871.

Es gracias a este conflicto que finalmente el reino de Prusia logra concretar el tan añorado sueño del pueblo alemán, unificar a toda la nación en un gran Estado, formando de esta manera el Imperio alemán, desde luego en torno a Prusia, que agruparía a diversos y minúsculos estados alemanes que nunca pudieron cohesionarse, tanto durante como después de la vigencia del Sacro Imperio Romano Germánico.

Por el Tratado de Fráncfort, Bismarck impuso una dura paz a Francia: le fueron arrebatadas las provincias de Alsacia y Lorena, ricas en minas de carbón y de hierro, además de imponérsele el pago de grandes sumas de dinero en concepto de reparaciones de guerra.

Lo que llama mucho la atención y merece ser mencionado, es la idea de soberanía de este nuevo Estado y de donde emana la misma.

"La soberanía, precisa Bismarck, no pertenece al emperador, sino al conjunto de los gobiernos federados", estos delegan a sus representantes en el "Consejo Federal" (Bundesrat), que no es una Cámara Alta, sino un Congreso permanente que participa del poder legislativo e incluso en ciertas prerrogativas del ejecutivo. Los Estados gestionan sus propios asuntos, con excepción de los que delegan al Imperio, guardando el uso de todos los impuestos directos, y contemplan la financiación de las instituciones centrales con "contribuciones registrales", cuyo importe puede dar lugar a discusiones. En pocas palabras, el particularismo ha quedado sólidamente protegido (...) (Ayçoberry, 1988, p. 126).

Como se observa de la anterior cita, el nacimiento de este nuevo estado federal, tiene sus cimientos en el espíritu del pueblo alemán, en el deseo de una nación por integrarse y constituirse como un actor internacional de peso en el escenario internacional, pero sin perder en gran medida la individualidad de cada uno; por ello es que el D.I. termina siendo 
la herramienta jurídica, que gracias a los grandes niveles de integración comercial y económica antes mencionados, se pudo, por libre voluntad de los Estados germánicos, constituir a un nuevo Estado, Alemania.

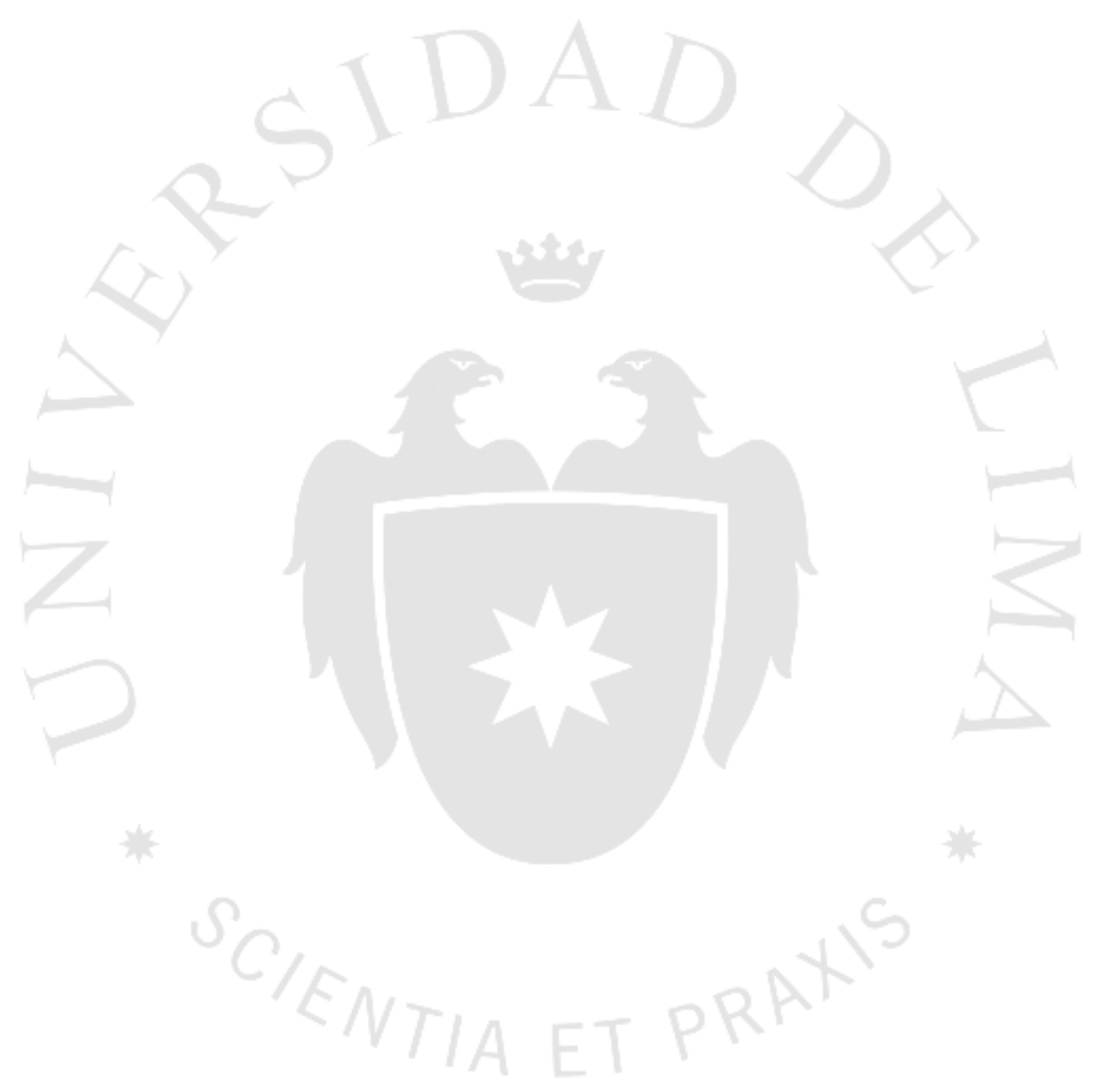




\section{Conclusiones}

A lo largo de la presente investigación, se detectó como problema general la falta de consenso por parte de los académicos especialistas en la materia, para determinar los orígenes, así como el momento histórico en el que surge el DI.

Una primera posición sostiene que el momento histórico en el que surge, se encuentra en los albores previos a la Segunda Guerra Mundial con el Congreso Paneuropeo de Viena de 1926, el cual habla ya no de Europa como un espacio geográfico, sino como un conjunto de valores que confirman una entidad común, tal como lo mencionan (Mammarella \& Cacace, 1998).

Por otra parte, Robles Morchón (1996) y Falcón (2012) consideran que el nacimiento del DI, se da en el contexto de la Segunda Guerra Mundial, tomando como puntos de partida la fundación del BENELUX en 1944, El Plan Marshall en 1947, la Organización Europea de Cooperación Económica (OECE) en 1948, el Consejo de Europa de 1949, de cuyo marco se suscribió en 1950 el Convenio Europeo de Derechos Humanos y Libertades Fundamentales, de cuya protección se haría garante al Tribunal de Derechos Humanos de Estrasburgo y finalmente la Comunidad Europea del Carbón y Acero (CECA) de 1951.

En esa misma posición, José Manuel Sobrino Heredia, en su artículo "Algunas consideraciones en torno a las nociones de Integración y de Supranacionalidad", establece que el Derecho de Integración es una institución jurídica nueva con características propias que nace al finalizar la Segunda Guerra Mundial como resultado de relaciones interestatales con objetivos en conjunto que iban de la mano de la cooperación entre Estados en materia económica, social, cultural o política (Sobrino Heredia, 2001).

Ante esta pluralidad de posiciones ¿qué se puede concluir?

En primer lugar, los autores coinciden en el origen europeo del DI, premisa con la cual se coincide plenamente, aunque no por los ejemplos o argumentos antes señalados.

En segundo lugar, los mismos autores coinciden, aunque no de forma exacta, en que este Derecho nace y se desarrolla en el siglo XX y toman al proceso integrador europeo en sus múltiples fases (CECA, COMUNIDAD EUROPEA, EURATOM, UNION EUROPEA, 
entre otros) como el nacimiento formal del DI y al Derecho Comunitario Europeo como su consolidación; sin embargo (y este es el principal punto de divergencia con las fuentes antes citadas), a lo largo de la presente investigación se encontró que, si bien efectivamente el lugar origen es europeo, el momento histórico en el que este nace, fue en el siglo XIX, teniendo al proceso de unificación germánico (1815-1871) como proceso integrador que dio origen de manera formal el DI y al II Reich como la consolidación del mismo.

Habiendo dejado posición sobre el dónde y el cuándo nace el DI, es necesario sentar posición sobre el origen mismo, así como sus propias características, antes de continuar defendiendo la hipótesis del origen germánico de este Derecho. Es en esta búsqueda por dar respuesta a esas interrogantes, que se encuentra un problema puntual: No existe una posición uniforme sobre estos, hallando dos posiciones: El DI como subcategoría del DIP y el DI como rama independiente del Derecho.

Como principal argumento para defender la condición intrínseca del DI en el DIP, encontramos la naturaleza jurídica de los tratados fundacionales (elementos nucleares y constitutivos de OS y por ende del DI), los cuales al ser un tipo de tratado - y al ser el tratado el objeto material por excelencia del DIP-, caen bajo el amparo y alcances de esta rama del Derecho y por ende se establece una subordinación del primero con el último.

En esta misma línea argumentativa, encontramos a Moorhead, que sostiene que, para la comprensión del Derecho de Integración como parte del Derecho Internacional Público, constituye un modo de explicar la cualidad rectora de los tratados sobre las prácticas institucionales de las organizaciones supranacionales, tomando como referencia el caso de la Unión Europea (Moorhead, 2012, pp. 143-144).

Asimismo, Acosta Estévez sostiene que el DI es un "particularismo jurídico" contrapuesto al "universalismo" que sería el DIP debido a que,

“(...) se caracteriza por los siguientes rasgos: 1) atendiendo al ámbito geográfico $(\ldots), 2)$ sobre la base de una producción normativa (...) en el seno de una organización internacional (...), 3) la creación de normas particulares del DCE tienen su razón de ser en los Tratados constitutivos de las Comunidades Europeas $\mathrm{y}$ en los procedimientos de elaboración normativa de los mismos; y 4) (...) desde 
el plano de la sectorización operada en la esfera del DIP, el DCE es una rama específica del DIP.” (Acosta Estévez, 2004, p. 2).

Tomando como ejemplo al Derecho Comunitario Europeo, Estévez ve a este como un “subordenamiento jurídico del ordenamiento jurídico internacional, (...) una subespecie internacional sui generis", cuyo fundamento en el Derecho Internacional Público se basa en el tratado fundacional de la organización internacional, como es el caso de la Unión Europea (Acosta Estévez, 2004, p. 7).

Siguiendo en la misma línea, Yésica Biquez menciona que los Estados se relacionan mediante acuerdos o tratados en función del Derecho Internacional Público, los cuales, establecen las diferentes formas en las que se va a desarrollar la integración. Por lo tanto, llega a la conclusión que el "Derecho de la integración es una rama especializada del Derecho internacional público que regula un proceso de integración de cualquier tipo. El derecho de la integración no es autónomo, sino una parte especial del Derecho Internacional" (Biquez, Pereyra, Estevez, Curbelo, Brunetto, \& Bas, p. 11).

En contra parte, para entender al DI como una rama independiente del Derecho, es necesario establecer los elementos que lo diferencian del DIP.

Para Robles Morchón (1996, p 29), el Derecho Internacional es el Derecho típico de la o coexistencia, cooperación $^{89}$, definiendo estos términos de la siguiente manera:

Coexistencia: <<existir con>>, <<existir al lado de〉>, sin que ese existir exija un esfuerzo especial de colaboración; simplemente se convive en una relación más o menos armoniosa. La coexistencia entre Estados es la meta mínima, y por eso mismo esencial, del Derecho Internacional. Cuando la coexistencia pacífica se deteriora y aparece el conflicto, allí está el Derecho Internacional para intentar que la paz se restablezca. El Derecho Internacional, en esta acepción primaria, no se propone otra meta que regular la paz y la guerra (y, en general, los conflictos entre los sujetos de Derecho Internacional, que principalmente son los Estados)

Cooperación: (...) un paso más en la dirección de la buena convivencia. Para que los Estados cooperen, no sólo han de coexistir, existir uno al lado del otro, sino que

\footnotetext{
${ }^{89}$ El resaltado es propio.
} 
además, han de proponerse metas comunes y realizar acciones comunes o coordinadas para alcanzar esas metas. La cooperación implica no una actitud pasiva (como ocurre en la mera coexistencia) sino activa; los cooperantes se aproximan entre sí en cuanto que realizan actividades para conseguir una meta común (Robles Morchón, 1996, p. 30).

Mientras que el Derecho Comunitario es el Derecho de la integración, entendiéndolo como el nivel más elevado de interacción entre Estados y que termina teniendo un efecto jurídico pleno, materializado en la creación de un nuevo ser jurídico: El Organismo Supranacional.

En ella los agentes participantes no sólo cooperan, sino que crean una entidad nueva en la que se integran, un nuevo ser jurídico que asume una personalidad distinta a la de los Estados que han acordado crearla; esa nueva entidad se propone la realización de determinadas acciones o políticas que los Estados no pueden ya realizar por sí mismos independientemente, puesto que han acordado que sea la nueva entidad la que asuma ese papel. Mientras que en la cooperación los Estados siguen siendo ellos mismos los que actúan cooperando, en la integración es el nuevo ente el sujeto de las acciones, si bien es cierto que el nuevo ente puede ordenar acciones a los Estados miembros; pero, en todo caso, lo relevante es que éstos no son los sujetos últimos de las decisiones adoptadas (Robles Morchón, 1996, p. 30).

Por ello, la primera característica del DI, es que este nace de la libertad de los Estados por querer alcanzar una integración con otros, en las formas, campos y alcances que éstos deseen y determinen ${ }^{90}$. No obstante, para que esta libertad sea materializada, se requiere de un acto formal de cada Estado miembro, la cesión de soberanía.

Los Estados se desprenden voluntariamente de parcelas de soberanía, las cuales serán posteriormente depositada en el OS, constituyéndose la supranacionalidad del OS, y el nacimiento del DC.

El DC supone la renuncia expresa de los Estados miembros, al ejercicio de su soberanía en las materias que estas hayan sido cedidas y acotadas por los Tratados Constitutivos; por consiguiente, dichas materias estarán reservadas

\footnotetext{
${ }^{90}$ Pudiendo ser comerciales, defensivas, económicas, políticas, aduaneras, entre otras.
} 
exclusivamente para el OS quien dispondrá de autonomía y soberanía propia para actuar en estos campos sobre los Estados que lo componen.

Sin que ello signifique que los Estados dejen de ser entes políticos soberanos, estos han pactado entre sí la renuncia al ejercicio de determinadas parcelas de su soberanía, transfiriéndolas a una nueva entidad los poderes correspondientes.

De ahí que el OS no genere un Derecho interestatal sino un auténtico Derecho interno, que tiene además la característica de que se integra en el Derecho interno de los Estados miembros. El OS es la fuente superior de normas en las materias reservadas por los Tratados, para lo cual dispone de una organización institucional propia que genera su propio ordenamiento jurídico (Robles Morchón, 1996, p. 31).

En esta misma línea, Sobrino Heredia considera a la supranacionalidad como la consolidación de la cesión de la soberanía estatal recogida en el Tratado Fundacional y, por ende, elemento constituyente del Organismo Supranacional.

En virtud de lo señalado por (Plata López \& Yepes Ceballos, 2009):

El Derecho comunitario en virtud de su supranacionalidad se constituye en un ordenamiento jurídico propio y especializado, distinto del Derecho interno y del Derecho internacional común, que se inserta en los ordenamientos jurídicos nacionales con valor superior a la ley nacional a la que desplaza o sustituye en forma directa y automática (principios de aplicación directa y preeminencia). Existe una ordenación jerarquizada de normas donde las superiores son la Constitución comunitaria y las que ocupan un rango inferior, las derivadas o secundarias ${ }^{91}$, que emanan de los órganos comunitarios. También se reconoce la importancia de estas normas en la conformación del bloque de constitucionalidad. ${ }^{92}$

\footnotetext{
91 Tales como Reglamentos, Directivas, Decisiones.

92 Por bloque de constitucionalidad hay que entender la relación de concordancia entre el Tratado Fundacional (Constitución Comunitaria) y las normas derivadas o secundarias (si se aplica la "Pirámide de Kelsen", el Tratado Fundacional (Constitución Comunitaria) sería la punta de la pirámide y las normas derivadas todas aquellas que se desprenden o sostienen dicha punta.)
} 
Por ello se hallan como elementos nucleares del proceso integrador a:

1. La libertad, entendida como el deseo de los Estados por integrarse entre sí, así como la libre determinación en las formas, campos y alcances en los que estos se integrarán.

2. La confianza, las buenas relaciones entre Estados reflejados en la confianza mutua o entre las partes.

3. La cesión de soberanía, entendida como el desprendimiento de la facultad estatal en el ejercicio de su poder natural en en las formas, campos y alcances sobre los que se va a constituir la integración, en beneficio del Organismo Supranacional.

Los cuales en su conjunto conducen al DI para que este termine materializando sus efectos en el Tratado Fundacional y posterior nacimiento del OS, y en el DC.

Finalmente, una característica central del DI y DC es el ámbito de aplicación, el cual va dirigido a los individuos que son ciudadanos de los Estados miembros, y, en segundo lugar, los Estados mismos. Marcando una clara diferencia con el DIP, ya que en este último los sujetos a los que van dirigidas sus normas son los Estados, excepcionalmente y residualmente a los individuos (en especial en materia de derechos humanos).

Entre los que sostienen la independencia del DI respecto al DIP encontramos una interesante reflexión de Orlando Guerrero Mayorga quien establece que el DC, siendo una forma más desarrollada del Derecho de Integración, viene a ser la manifestación más importante de integración entre Estados, ya que este goza de un sistema mucho más complejo que una simple cooperación entre países, ya que goza de ordenamiento normativo y de aplicabilidad inmediata en el tiempo, en cuanto se convierte vinculante para la normativa interna de los Estados (Guerrero Mayorga, 2005).

Por otra parte, Dromi, Ekmekdjian y Rivera sí reconocen el origen dentro del DIP, debido a que los tratados fundacionales nacen bajo el régimen de este último. Sin embargo, es con la creación de los órganos supranacionales que aquel se independiza progresivamente de este, a pesar de que todavía habrá una vinculación respecto al tratado fundacional, relación similar a la de la Constitución con las normas inferiores y subordinadas (Dromi, Ekmekdjian, \& Rivera, 1996, p. 71). 
En cuanto a dicha independencia progresiva, el DC no se compone únicamente de normas de DIP, sino que se integra también por otras normas de fuentes distintas a este último, como es el caso de los reglamentos, directivas, decisiones, etc., por lo que su dependencia del DIP, se halla únicamente en sus normas constitutivas (tratados), mas no en su desarrollo (Ortiz Ahlf, 2003, p. 16).

Como ejemplo a ese último punto se hizo mención al Derecho de la Comunidad Andina, el cual carece de influencias del Derecho Internacional Público en cuanto a su desarrollo y funcionamiento, a pesar de que sí es posible una vinculación entre ambos sistemas jurídicos (Carruitero Lecca, Gutíerrez Canales, \& Torres Lobato, 2005, pp. 48-49). Del mismo modo, se puede afirmar que la existencia de órganos de creación normativa en las organizaciones supranacionales configura un rasgo a tomar en cuenta respecto a la justificación de su autonomía (Novak Talavera, 2003, pp. 57).

En esa misma línea Alberto Zelada Castedo afirma que constituye un "sistema normativo autosuficiente en el sentido de que contiene en sí mismo todos los elementos para su desarrollo, interpretación y aplicación". Menciona, además, que, si bien se basa inicialmente en el DIP, su posterior desarrollo tiene como fundamento actos de naturaleza eminentemente distinta (Zelada Castedo, 1989, p. 24).

Por otra parte, (Molina del Pozo, 1990) opina que el DC es un conjunto de reglas que determinan la organización, las competencias y el funcionamiento de las Comunidades Europeas, y que ha sido el TJC quién ha declarado que este Derecho supone un orden jurídico propio, que se diferencia del orden jurídico internacional y que, también, es distinto del orden jurídico interno de los Estados miembros. Es precisamente ese orden jurídico propio, distinto del internacional y del interno de cada Estado miembro, lo que se denomina Ordenamiento Jurídico Comunitario.

Acorde con (Ortiz Ahlf, 2003, p. 14):

El Tribunal de Justicia de las Comunidades ${ }^{93}$ Europeas ha recordado continuamente el carácter propio, nuevo y autónomo del derecho comunitario,

${ }_{93}$ También conocido como Tribunal de Justicia Comunitario - TJC, o Tribunal de Justicia de la Unión Europea 139 
como un ordenamiento legal separado del derecho internacional y del derecho nacional, comenzando con la sentencia del Caso Gend and Loos en 1963 y Costa

V. Enel en 1994 en las cuales los jueces, describieron el Tratado de la Comunidad Europea como un tratado de naturaleza especial.

Si bien estas características, así como procesos de integración antes descritos dejan sentada de manera clara las diferencias y por ende la independencia del DI con respecto al DIP, no se responde a la interrogante antes planteada ¿Cuál es el origen del DI? Es por ello que en la presente investigación se presentó la siguiente hipótesis como respuesta a nuestro problema: El Derecho de Integración es una rama independiente del Derecho, cuyo origen se encuentra en la política internacional; es decir, reafirmar a la política como creadora del Derecho.

¿Por qué se sostiene a la política como origen del DI?

Porque la Política es el punto de partida del Derecho, siendo a partir de esta que se genera una relación simbiótica y necesaria entre ambos, en donde cada uno influye y transforma al otro; es decir, los procesos y desarrollos de la primera, impactan en el otro, demandando a que este último también evolucione y se adapte a los avances del primero, manteniendo la correlación entre ambos, puesto que el Derecho regula la realidad, pero también la realidad regula al Derecho, y al ser el ser humano un ser político (zoon politikoon), la realidad humana es una realidad política que influye de igual forma en el Derecho, cerrándose de esta forma la dialéctica entre uno y otro.

Por ello, es importante recalcar lo sostenido a lo largo de toda la investigación: la política al tener dos alcances de aplicación, uno local/estatal (dentro de un determinado espacio o territorio, en donde se estructura y materializan las relaciones de poder entre los individuos dentro de una organización social y/o político-administrativa que vela por sus intereses), y uno externo/internacional (en donde dichas organizaciones político-administrativas se relacionan con otras similares o equivalentes); se puede afirmar, que dentro de los Derechos, cuyos orígenes parten de la política, se encuentran dos vertientes, una orientada a la Política Internacional (Derecho Internacional Público y Derecho de Integración) y una a la Política Local (Derecho Constitucional). 
Sin embargo, si bien las teorías antes mencionadas reconocen un origen común del DI y el DIP, existiendo una relación entre estos dos Derechos, este origen no tiene como elemento común al "Tratado" -que es el objeto material por excelencia del DIP- sino las necesidades de la política internacional.

En esta misma línea, aunque sin hacer mención al DI, Martti Koskenniemi, en su obra "From Apology to Utopia, The Structure of Internacional Legal Argument" reconocía el origen político del DIP, (Koskenniemi, 2005).

El DIP como el DI son Derechos que nacen de necesidades políticas, específicamente en la necesidad de restablecer el equilibrio del escenario internacional después de la guerra, mantener la paz y evitar un nuevo enfrentamiento armado entre los Estados garantizando la supervivencia, así como el bienestar de los mismos. Es decir, estos Derechos nacen de las necesidades de la Política Internacional, confirmándose que finalmente es el Derecho la herramienta de la Política, el medio, por donde esta va a buscar alcanzar los objetivos que esta persigue.

En esta búsqueda por satisfacer las necesidades creadas por la política, surge la siguiente interrogante ¿qué tan eficientes son estos Derechos en restablecer el equilibrio del escenario internacional después de la guerra, mantener la paz y evitar un nuevo enfrentamiento armado entre los Estados?

Como bien se desarrolló en esta investigación, el DIP fue el resultado de un proceso que tuvo como punto de partida la Paz Religiosa de Augsburgo (1555) en donde se establecieron parte de los principios del DIP, tales como "Principio de Soberanía", "Principio de No Intervención" y "Principio de Prohibición del uso de la fuerza"(Garcés Ávalos, 2016), principios que a simple vista nos dan una salida a la problemática relación existente entre actores internacionales a lo largo de la historia; sin embargo, vemos que la teoría no siempre se ha visto reflejada en la realidad, debido a una serie de características:

En primer lugar, la carencia de una autoridad internacional dotada con el poder legal para imponer nuevas reglas vinculantes sobre todos los Estados, así como hacer cumplir las soluciones de controversias entre los mismos, esta carencia de instituciones fuertes y cargadas de un poder real, fortalece "la libertad" de los Estados de acatar o someterse a las 
normas y soluciones de controversia del Derecho Internacional Público según sus intereses (Pastor Ridruejo, 2012; Lauterpacht, 1970).

Asimismo, (Maestre, 2007, p. 316) siguiendo en la misma línea señala lo siguiente, (...) no existe la "sociedad general", un espacio social universal, provisto de gendarmes que garantices la aplicación de una ley planetaria. La única regla de comportamiento internacional es, pues, la libertad, es decir, la ausencia de reglas (la "ley de la jungla"); lo cual equivale a decir que el único principio de comportamiento entre los estados es el nacionalismo. La moral universal se detiene en el umbral de las relaciones internacionales.

Por ello es que

Los Estados, al igual que los individuos, tienen esferas en las cuales actúan en función, únicamente, de su voluntad (los derechos negativos); pero, a diferencia de los individuos, los estados no tienen por qué conformarse con un código que les atribuya derechos positivos, por la sencilla razón de que tal código no existe. En efecto, para que el derecho se pueda ejercer, es preciso, necesariamente, que exista un espacio social en el interior del cual la colectividad pueda imponer la aplicación de la ley (éste es, precisamente, el Estado de Derecho). (Maestre, 2007, p. 316.

En ese sentido, la jurisdicción de tribunales internacionales es en principio de carácter voluntario por parte de los Estados, incluso en los casos que los Estados se sometan a la jurisdicción de Cortes Internacionales, estas carecen del poder suficiente para poder hacer cumplir sus fallos mediante el uso de la fuerza en caso de desobediencia ${ }^{94}$.

En segundo lugar, las normas consuetudinarias del DIP no ofrecen suficiente precisión y claridad deseable -asimismo, adolecen de mecanismos eficaces y lo suficientemente disuasivos para garantizar su cumplimiento, más que la reciprocidad entre Estados-, mientras que la norma escrita cuenta con un ámbito de aplicación mucho más restringido y la cual solo afecta a las partes que se consienten en obligarse, introduciendo así cierta dosis de relativismo y de discrecionalidad en el Derecho Internacional para los destinatarios y

\footnotetext{
${ }^{94}$ Como ejemplo material para este punto se utilizó el incumplimiento de Colombia a la sentencia de la CIJ en el diferendo marítimo con Nicaragua, que, si bien se le otorgó soberanía a esta última sobre una cantidad determinada de kilómetros cuadrados, a la fecha Colombia no acata el fallo y no entrega ese mar.
} 
creadores de esta rama del Derecho tal como lo señalan Garcés Ávalos y Pastor Ridruejo, (Garcés Ávalos, 2016; Pastor Ridruejo, 2012).

Por todo lo antes señalado es que podemos afirmar que la gran debilidad del DIP y por ende fracasa como herramienta para garantizar la paz, es que es un Derecho que, frente al vacío de poder coercitivo, apela a elementos morales (idealistas) para logar efectividad, el DIP es “el Derecho la exhortación”, cuyo punto de partida fílosófico es el idealismo político.

El idealismo propone que el ser humano es un ser social por naturaleza y que, a través de las virtudes del mundo de las ideas, los hombres actúan con ética. Justamente es a través de la ética que se busca alcanzar la justicia como la mayor de las virtudes (Axelrod, 1994).

De esta forma, se halla un primer componente moral, es decir la práctica de las virtudes y la conducta ética, como medio para alcanzar la justicia, entendida esta última como un fin que nos lleva a una convivencia armoniosa entre individuos (Axelrod, 1994).

Para los idealistas, las relaciones internacionales tienen que regirse por componentes éticos, que garanticen la paz entre estos, ya que:

Desde sus orígenes, los idealistas rechazaron la idea de que los conflictos eran una condición natural de las relaciones entre Estados y que sólo podían ser superados mediante el equilibrio de políticas de poder y la formación de alianzas en contra de las naciones que amenazaran el orden mundial (Jiménez González, 2009).

Immanuel Kant en su obra "La Paz Perpetua" (Kant, 1985, p. 16), esboza la creencia de que la razón otorgará libertad y justicia a las relaciones internacionales, requiriéndose para ello la transformación de la conciencia individual, el constitucionalismo republicano y un "acuerdo" o tratado federal entre estados para abolir la guerra.

Por ello, el idealismo parte de premisas incompletas, que dan una interpretación bastante limitada de la realidad. En primer lugar, el hombre por su capacidad de razón puede someter sus instintos e impulsos y basar su conducta sobre la moral y la ética. En segundo lugar, se observa que los idealistas, en la corriente de las relaciones internacionales, llevan este criterio a los Estados en donde si los Estados se relacionan con ética y moral se podrá alcanzar la 
paz. Y en tercer y último lugar, que para que esa paz sea duradera, deberá existir una organización internacional nacida de la voluntad de los Estados de obedecerla -por razones “ético-morales”- para que vele y garantice la misma.

Por lo antes señalado, se puede afirmar que la principal utilidad y hasta fortaleza del DIP, es que ayuda a ordenar el escenario internacional después de un periodo de caos o guerra toda vez que existe un interés común entre los actores internacionales: organizar el escenario internacional, muestra de ello se observa en toda la serie de conflictos armados desde Augsburgo, hasta la Segunda Guerra Mundial, donde justamente es después de estos conflictos en la historia del DIP, donde se encuentran los momentos icónicos del mismo; sin embargo, estos mismos conflictos se han seguido repitiendo a lo largo de la historia, ya que al no existir un mecanismo coercitivo que mantenga o garantice la cooperación y la paz entre Estados - en vista que los intereses que los unen son cambiantes -, es que finalmente el DIP solamente es un mecanismo que organiza el escenario internacional tras tiempos de guerras o crisis, mas no es garantía de manutención del orden obtenido, por justamente la volatilidad de los intereses de los Estados, así como falta de mecanismo coercitivos antes señalados, poniendo en evidencia la gran debilidad y fracaso del DIP como herramienta para preservar y garantizar una paz duradera y perpetua, ideal que, por este medio, es utópico.

Frente a lo inexacta de la lectura idealista de las relaciones internacionales y del DIP, es que, en el realismo político, se puede llegar a una lectura más exacta del escenario internacional, así como de los actores de este, para poder comprender al DI como la herramienta jurídica que mantiene y garantiza la paz en los espacios geográficos donde este se aplica.

Ya Maquiavelo en su obra "El Príncipe” obra nuclear sobre la cual se desarrolla y constituye el realismo político, tanto para la política local como la internacional, reconoce al ser humano como ser egoísta y violento que se encuentra en constante lucha por satisfacer sus pretensiones y deseos, y es sobre estas características innatas de la naturaleza humana, que esboza la idea de "política" como un medio por el cual contener esa naturaleza negativa de las personas, apelando a una separación entre la moral del gobernante -o el Estado- sobre la moral individual, siendo la separación de moral y política el segundo gran aporte de este. Reconociendo la importancia del Derecho como el medio por el cual el poder político logra 
contener el caos y tendencia natural a la anarquía del ser humano, siendo el garante del bienestar y de la vida en sociedad. (Sabine, 1994, p. 273; Donskis, 2011; Maquiavelo, 1978)

En esa misma línea Hobbes continua lo actuado por Maquiavelo conceptualizando a través del método científico, el deseo de supervivencia como principal estímulo a la conducta humana, teniendo por ello dos formas de canalizarlo, una instintiva, irracional y "presocial" ${ }^{\prime 95}$ que termina fallando en el objetivo de garantizar la supervivencia del individuo puesto que al reconocerse al ser humano como un ser egoísta, deseoso de mantener lo que posee y ampliarlo, esto lleva a una constante lucha, muchas veces violenta, con sus semejantes-, justamente por ello, es que a través de la razón humana, el ser humano pacta con otros para que cada individuo ceda sus parcelas de poder en aras de que este "Leviatán" sea quien monopolice el poder de la fuerza, garantizando el orden, la seguridad y la subsistencia de las personas.

Asimismo, dentro de la esfera de política local, el pensamiento Hobbesiano se mantiene vigente a través de la noción de cesión del poder, materializada en el contrato social o constitucionalismo, por ello es que existe una mayor similitud entre el DI y el Derecho Constitucional, el cual se desarrollará más adelante.

Lo antes mencionado, empalma con al ámbito de alcance local/estatal de la Política, el cual encuentra en el Derecho Constitucional a su Derecho por excelencia, el cual tiene su origen y antecedente directo en el Pacto Social, el cual constituye el medio jurídico fundamental a través del cual las sociedades que habitan un determinado territorio pueden alcanzar una organización político-administrativa que en un primer lugar, garantice la supervivencia y seguridad de los individuos que la componen; en segundo lugar, garantice el bienestar y desarrollo en las múltiples esferas de la vida cotidiana de estos individuos -económica, académica, científica, entre otras-; para que finalmente, al alcanzar el bienestar antes mencionado y por ende un mayor número de individuos que la componen, se estructure una organización político-administrativa, que permita a esas sociedades poder tener proyección

\footnotetext{
${ }^{95}$ Se podría considerar que incluso para Hobbes, el ser humano no es un ser social por naturaleza, sino que por fines prácticos, se "adapta" a la sociedad en aras de garantizar su supervivencia, ya que como señala (Sabine, 1994) "La sociedad es meramente un cuerpo "artificial", un nombre colectivo que describe el hecho de que los seres humanos encuentran individualmente que les resulta ventajoso el cambio de bienes y servicios".
} 
en el escenario internacional, para que de esa forma puedan correlacionarse y seguir proyectando las propias características humanas (el deseo de mayor poder, de asegurar sus bienes y buscar el aumento de los mismos, entre otros), en espacios geográficos y demográficos, mucho más amplios en los que primigeniamente estos se desarrollaban. Este proceso jamás se hubiera alcanzado en los elementos antes descritos, así como la capacidad de proyección en el escenario internacional, de no ser por el Pacto Social inicialmente y luego con el Derecho Constitucional.

El Pacto Social es el acuerdo emanado del Poder Constituyente entre todos los individuos de una sociedad, el cual determina los derechos y obligaciones de todos estos, renunciando cada uno a sus propias parcelas de poder, para depositarlo en un ente rector, encargado de normar y hacer cumplir lo pactado entre los individuos, el Estado, el cual tiene como elementos pueblo, territorio y poder.

El pueblo, es el espíritu del Estado mismo, dado que el pueblo otorga su poder al Estado con las características propias que este tenga, siendo este último el reflejo de los individuos que lo conforma, ya sea por el o los idiomas, la historia, la cosmovisión y la moral reflejada en su ordenamiento jurídico. Estas características terminan siendo la proyección del "espíritu del pueblo".

El territorio, el cual es el espacio geofísico, sobre el cual el pueblo se ubica y en donde el poder del Estado termina siendo aplicado, es decir, el territorio es el límite físico del alcance del poder estatal sobre sí mismo, su pueblo, todos los individuos que se encuentren en este y los recursos dentro de este espacio geofísico. Asimismo, dentro del escenario internacional, es la materialización del Estado, en donde alcanza una interrelación física con otros, gracias a sus límites territoriales sobre los cuales ejercerá su propio poder frente a terceros, es decir donde el Estado ejerce su soberanía.

Y finalmente el poder, pero no entendido como un concepto etéreo o abstracto, el poder entendido como una organización, una estructuración sobre la cual el Estado mismo se manifiesta sobre su población y territorio, pero también sobre el escenario internacional.

Como se observa, existe una estrecha correlación entre los 3 elementos del Estado: pueblo que da poder, pero con las características propias del mismo, el cual se materializa en una 
Constitución -Pacto Social-, la cual determina las características y formas del Estado mismo, ejerciéndose en un territorio, pero a su vez dando forma al poder del Estado en conformidad con la visión e intereses del pueblo mismo, pero que a su vez recaerá sobre este, en aras de garantizar su propia seguridad y satisfacer sus intereses.

Por ello, es propio afirmar que el Estado es la proyección de la moral colectiva y del pueblo mismo, teniendo los Estados las mismas motivaciones que Hobbes identifica: seguridad y bienestar, pero también un deseo egoísta por satisfacerlo (Maquiavelo); por esta razón es que vemos la conflictividad de las relaciones entre Estados a lo largo de la historia, ya que por su egoísmo y de satisfacer sus deseos de seguridad y bienestar es que terminan entrando en conflicto.

Hay que tener presente que el DIP tiene como objetivo garantizar la co-existencia, y en última instancia, la cooperación entre los Estados con la finalidad de garantizar la paz y regular los conflictos entre los mismos. Es decir, mantener un equilibrio de poder entre los actores internacionales dentro del escenario internacional. Sin embargo, dicho objetivo, busca conseguirlo a través de una visión idealista del escenario internacional, carente de un poder superior dotado de una capacidad coercitiva que garantice el equilibrio logrado, por lo que no hay una plena efectividad en alcanzar los objetivos que este persigue.

Por otra parte, el DI nace de la convergencia de intereses entre Estados, que de forma libre y voluntaria acuerdan ceder parcelas de su soberanía, para depositarla en un OS dotado de personería jurídica distinta e independiente de estos, con la capacidad de hacer cumplir coercitivamente lo pactado en el Tratado Fundacional y en todas aquellas decisiones / legislaciones comunitarias derivadas del mismo. Por ello, posee un mayor grado de efectividad al momento de mantener y garantizar la paz, así como el orden internacional, aun cuando sus efectos solo se limiten a una porción geográfica limitada del escenario internacional.

¿Cómo se constituye y qué garantiza el éxito de un proceso de integración a través del DI?

El proceso jurídico de integración a través del DI, que deviene en la constitución de un Organismo Supranacional, resulta equivalente al proceso constitucional de creación de 
Estados; por ello que en la presente investigación se sostuvo que el OS es el "Súper Leviatán" y el Tratado Fundacional un "Pacto Social Internacional.

En el proceso de crear un OS el objeto material sobre el cual este se constituye termina siendo el Tratado Fundacional; este proceso, tiene su origen en el poder de los Estados, es decir la soberanía estatal. Los Estados, por considerar conveniente a sus intereses, así como los fines que estos persiguen, ceden parcelas de su soberanía junto con otros, en los ámbitos, alcances y formas que estos previamente hayan acordado, constituyéndose de esta forma, la supranacionalidad, así como un nuevo sujeto con personalidad jurídica internacional, cuyo origen no radica directamente del poder constituyente de los individuos, sino de la soberanía estatal.

De esta forma, la renuncia al ejercicio absoluto de la soberanía que todo Estado posee, se da por ceder dichas parcelas al OS, el cual será el receptor de ese poder Estatal, y podrá ejercerlo exclusivamente en los ámbitos, alcances y formas que se haya pactado en el Tratado Constitutivo entre todas las partes; empoderando al OS para que pueda regular e intervenir sobre los Estados que lo componen en todas aquellas materias previamente establecidas, garantizando de esa forma la seguridad de alcanzar los objetivos por los cuales este OS fue constituido.

No obstante, para garantizar el éxito de un proceso de integración a través del DI, en la presente investigación se propuso la idea de cuatro pilares o elementos los cuales explicamos a continuación:

1. La supervivencia como primer pilar de integración.

Como bien ya lo mencionó Restrepo Abondano (1989, pp. 84 - 87),

El hombre tiende naturalmente a asociarse: esa es la última explicación de los grupos familiares, aldeanos, y de la comunidad política. La Polis, por ser el único grupo social autárquico, es anterior a la familia y al individuo, que se encuentran en la misma relación en que se hallan las partes con respecto al todo.

(...) "Al unirse los hombres, necesariamente aparece el fenómeno de la autoridad: unos mandan y otros obedecen. Cada forma de asociación demanda sus propias 
autoridades y normas, ya que toda convivencia entre individuos en sus múltiples niveles (familias, aldeas, comunidades, naciones, entre otros) conlleva a la existencia de un cuerpo normativo (consuetudinario o escrito) que regule y garantice la convivencia pacífica y el orden social, lo cual finalmente conlleva al bienestar general de todos los individuos."

En esa misma línea, acorde con Aguilera Barchet (2014, p. 54) tomo como ejemplo a las polis griegas y explica lo siguiente: la base sobre la cual se constituyen las Polis es el "sinecismo" (synoikism ós, literalmente "cohabitación"), término que alude a un proceso histórico por el cual una serie de poblaciones aisladas se unen para protegerse mutuamente formando una ciudad-estado.

Ello porque los actores internacionales, principalmente los Estados y países, tienen una tendencia natural al conflicto, lo cual supone un riesgo a su seguridad o deseo de bienestar, lo cual lleva a que estos busquen integrarse en aras de poder aumentar sus probabilidades de supervivencia dentro del escenario internacional, constituyéndose alianzas o apostando por mecanismos de integración más fuertes y eficientes como los planteados en el DI.

2. La economía como segundo pilar de integración.

Una vez garantizada la supervivencia del colectivo, surge la posibilidad de cooperación entre las partes, apostando principalmente por elementos comerciales tales como trueque o comercio mayor bienestar. ¿Pero por qué a la economía? Porque esta tiene como finalidad satisfacer el deseo natural por el bienestar que todo individuo posee, siendo pieza o eje central no solo en los procesos de integración de colectividades primitivas o antiguas, sino en el Derecho de Integración mismo, ya que a través de la búsqueda del bienestar económico es que se van construyendo los procesos integradores entre Estados mediante este Derecho.

Los Estados miembros no se conforman únicamente con la seguridad de su propia existencia, sino que, motivados por el deseo natural de un mayor bienestar y prosperidad, encuentran muchas veces sinergias entre sus propias economías que llevan a mayores niveles de ganancia para todos, por es que en el DI se encuentra un gran componente comercial tal como lo señaló (Balassa, 1964) con las fases económicas del proceso de integración (Zona de Libre Comercio, Unión Aduanera, Mercado Común y Unión Económica) y que va de la 
mano con los tiempos actuales en donde por la globalización se apuesta por un libre comercio y mercado.

3. La religión como tercer pilar de integración

La religión cumple un rol preponderante ya que históricamente ha sido fuente de legitimidad del poder, así como las fuentes de los diversos códigos morales o éticos, es decir cuerpos normativos, puesto que estos radicaban en elementos trascendentes a la naturaleza del hombre. Sin embargo, no se puede quedar solamente con la religión como fuente de legitimidad del poder de la autoridad, ya que esta cumple otro rol más importante es el elemento de unidad e integración de los individuos.

Como ejemplo a este último punto se encuentra a la nación judía, el cuál por muchos siglos vivió disperso por el mundo, siendo una nación sin territorio hasta 1948 que se funda el Estado de Israel,

La dimensión social - política y jurídica- de la Biblia es trascendental, pues permitió que durante 18 siglos, los judíos sobreviviesen como pueblo, sin patria, dispersos por todo el mundo, y que a pesar de la "diáspora", el pueblo judío siguiese manteniendo su religión y su derecho, a pesar de no tener un territorio fijo. Un ejemplo único en la historia de cómo la religión puede convertirse en la base estructuradora de una sociedad y en fuente de su derecho (Aguilera Barchet, 2014, p. 82).

Asimismo, la religión no solo termina manteniendo la cohesión social dentro del colectivo de personas, sino que, a su vez, termina influenciando y construyendo la cosmovisión de este, puesto que sienta las pautas ético-morales sobre las cuales los individuos y la sociedad desarrollarán su propia cultura.

4. La cultura como cuarto pilar de integración

La cultura, como cuarto y último pilar de integración, termina siendo la culminación de un largo proceso que se va desarrollando paralela y paulatinamente con el desarrollo mismo del ser humano y los pilares de integración antes mencionados (instinto de supervivencia, economía y religión). 
Por ello se desarrolló una definición de cultural la cual es considera un conjunto de conocimientos, saberes (SUPERVIVENCIA - ECONOMÍA), costumbres, creencias y pautas de conducta de una colectividad de individuos (RELIGION), desarrollados en la interacción con el espacio geográfico -contribuyendo finalmente la adaptación con el mismo- y tiempo en el que habitan, así como el medio con el que satisfacen necesidades de todo tipo.

Acorde con Samuel Huntington, la cultura constituye una entidad cultural que da forma a las diversas civilizaciones que habitan en el escenario internacional. Ciudades, regiones, grupos étnicos, nacionalidades, grupos religiosos, son entidades que tienen distintas culturas a diferentes niveles de heterogeneidad cultural (Huntington, 2001, p. 126).

Para poder comprender mejor lo antes citado, el autor establece el siguiente ejemplo:

La cultura de una ciudad del sur de Italia puede ser distinta de una ciudad de la Italia del norte, pero ambas tendrán en común una cultura italiana que las distingue de las ciudades alemanas. Las comunidades europeas compartirán, a su vez, rasgos culturales que las diferencien de las comunidades árabes o chinas. Pero árabes, chinos y occidentales no son ya; sin embargo, parte de ninguna entidad cultural más amplia. Constituyen Civilizaciones (Huntington, 2001, p. 126).

Finalmente, el autor finaliza su definición de Civilización con la siguiente idea:

Una civilización es pues, la más elevada agrupación cultural de gentes y el más amplio nivel de identidad cultural que poseen los pueblos y que es en suma lo que distingue a los hombres de las demás especies. Una civilización se deja definir por elementos objetivos comunes, como son el lenguaje, la historia, la religión, las costumbres y las instituciones, y también, a su vez por las autoidentificación subjetiva de un pueblo (Huntington, 2001, p. 126).

Esta definición lleva a concluir que los procesos de integración tienen mayor grado de éxito y de viabilidad en la medida que exista una mayor homogeneidad cultural, mejor aún si los Estados son parte de una misma civilización. 
En primer lugar, por las semejanzas, tal como ya se desarrolló a lo largo de la investigación, en la medida que los elementos a integrar se sostengan en los mismos pilares de integración, el proceso será sostenible y viable en el tiempo.

En segundo lugar, porque es más fácil integrar, unir iguales; se puede integrar dos moléculas de agua de forma natural entre sí, pero naturalmente no puedes integrar una de agua y aceite por las características intrínsecas que estas poseen.

Y finalmente, porque Estados pertenecientes a distintas civilizaciones, terminarán confrontando entre sí por las diferencias naturales que estos llevan en sí mismos, tales como la historia, el idioma, y lo más importante, la cosmovisión.

Los pueblos que pertenecen a civilizaciones destinas tienen puntos de vista diferentes sobre las relaciones entre Dios y el hombre, el individuo y el grupo, el ciudadano y el Estado, entre padres e hijos, entre marido y mujer, e igualmente opiniones distintas sobre la relativa importancia de los derechos y las responsabilidades, de la libertad y la autoridad, de la igualdad y la jerarquía (Huntington, 2001, pp. 127-128).

De todo lo antes señalado., es importante contrastar las hipótesis antes expuestas con el proceso de unificación alamana, caso práctico que se escogió para demostrar en la realidad toda la teoría antes propuesta.

Por ello, cuando se habla de la Unificación Alemana, es sin duda de un episodio trascendental, no solo de la Geschichte des deutschen Volkes (historia del pueblo alemán), sino de la historia del Derecho, puesto que es con este proceso, donde se demuestra el objetivo principal de la presente investigación: El D.I. tiene sus orígenes en la Política y es en el proceso de unificación germánico del siglo XIX, donde finalmente se hace una realidad jurídica y una herramienta en el escenario internacional.

Frente al vacío dejado por el fin del Sacro Imperio Romano Germánico tras las guerras napoleónicas, queda una compleja y plural organización política de los pueblos alemanes, ya que este ayudaba a organizar y de alguna manera simplificar la esta compleja estructura, ello llevó que frente a la pluralidad de actores germánicos, Napoleón creara una nueva organización: La Confederación del Rhin (1806-1813) la cual organizaba a los reinos y 
ducados de proporciones medianas, dejando fuera de esta a las dos grandes potencias principales: Austria y Prusia.

La exclusión de estas dos potencias germánicas tiene su explicación en la teoría que se ha propuesto en la presente investigación: “Teoría de la Gravitación de los Estados”, la cual consiste en que Estados grandes o poderosos, generan una fuerza de influencia similar a la gravedad, haciendo que Estados más pequeños giren en torno a este y finalmente actúen acorde con la influencia del primero. No obstante, a mayor fuerza o influencia, mayor la posibilidad que estos Estados más pequeños terminen siendo absorbidos por el grande o poderoso.

Si esta teoría se contrasta en el presente caso, se observa que las pretensiones de Napoleón fueron las de poder establecer una zona de influencia dónde ejercer su control sobre los territorios alemanes (es decir, que estos Estados más pequeños “orbiten" en torno a los intereses de Francia); sin embargo, si en esta ecuación, incorporaba a un tercer Estado de mayor poder o dimensión (Prusia o Austria), estos hubieran generado una contra-fuerza que mermara los intereses franceses, más aún porque estos pequeños Estados germánicos poseían mayores similitudes étnicas, históricas, culturales, entro otros factores, con los dos antes mencionados, haciendo mucha más fácil y sencillo orbitar entorno a estos antes que con Francia por existir más elementos comunes que solo el poder económico o militar.

Tas la derrota de Napoleón, surge el Congreso de Viena el cual fue un encuentro internacional cuyo objetivo fue el de restablecer las fronteras de Europa tras la derrota, así como la de reorganizar y replantear las ideologías políticas del Antiguo Régimen. La finalidad era que Europa retorne a la situación anterior a la Revolución francesa (1789), no sólo restableciendo las fronteras nacionales modificadas hacía casi 20 años, sino además para asegurar un equilibrio de poder que evitase otra serie de conflictos armados a gran escala, como fueron las Guerras revolucionarias francesas y las Guerras Napoleónicas. Sin embargo, si bien las fronteras fueron restablecidas, la simplificación de los territorios alemanes, reunidos en la Confederación del Rhin, se mantuvo, aunque con ciertas variaciones. 
Ahora pasaría a llamarse Confederación Germánica incorporándose a los dos grandes Estados germánicos ausentes en la otrora Confederación del Rhin: Austria y Prusia, siendo estos los que finalmente terminarían por ser los que competirían entre ambos por consolidar su poder e influencia dentro de la nueva confederación ya que no estaba Francia como principal potencia sobre la cual los medianos y pequeños Estados germánicos orbitaban alrededor de estos.

La Confederación Germánica estaba destinada a mantener el equilibrio entre los estados, no nace de golpe, con el entusiasmo, sino fruto de laboriosas negociaciones (1815-1820). No es un estado, sino una Liga (Bund) entre "príncipes y ciudades libres" (...).

No es una alianza muy sólida: el tratado tiene concretamente dos objetivos: seguridad e independencia de los contratantes, pero la defensa contra los peligros exteriores queda en un segundo plano; el ejército confederal no se organiza hasta 1821 por la simple yuxtaposición de cinco cuerpos de ejército sin jefe: tres austriacos tres prusianos, uno bávaro y tres mixtos (...).

Finalmente, se le podría definir como una sociedad de seguros mutuos contra los trastornos internos; está previsto que a petición de un soberano, o incluso sin demanda si está impedida, la Dieta ${ }^{96}$ podrá proceder a una “intervención” para restablecer el orden en un estado y si en algún caso el mismo soberano quisiera separarse del camino recto, podría verse amenazado por una "aplicación confederal" (...) "unidad para el exterior, diversidad para lo interior" (Ayçoberry, 1988, p. 35).

Finalmente, gracias a la injerencia napoleónica es que se propician las condiciones para que se diera la integración germánica toda vez que el número de actores internacionales germánicos se reduce, al reducir esta enorme pluralidad, es más fácil organizar y estructurar a los estados germánicos que subsisten. Asimismo, es gracias a este personaje histórico y a Francia que se observa cómo se materializa el primer pilar sociológico de la integración: la supervivencia. Ya que, de la experiencia sufrida bajo los embates y medidas impuestas por esta última, es que los Estados germánicos supervivientes encontraron en la integración el

\footnotetext{
${ }^{96}$ La Dieta, que no era un parlamento de representantes elegidos por el pueblo, sino un congreso de delegados con sede en Fráncfort
} 
mecanismo sobre el cual podían aumentar sus chances de supervivencia dentro del escenario internacional y no volver a ser eliminados o bien subyugados bajo la órbita de un actor internacional que no tuviera relación o semejanza alguna con estos (los pilares de cultura, religión principalmente). Muestra de ello se observa también en el tratado fundacional de la Confederación Germánica, que establecía fines defensivos, tanto para frentes externos como internos de cada uno de los actores partícipes de esta

(...) está previsto que, a petición de un soberano, o incluso sin demanda si está impedida, la Dieta podrá proceder a una “intervención” para restablecer el orden en un estado y si en algún caso el mismo soberano quisiera separarse del camino recto, podría verse amenazado por una "aplicación confederal" (...) "unidad para el exterior, diversidad para lo interior" (Ayçoberry, 1988, p. 35)

Es en este punto que se encuentra el primer precedente histórico a un OS dentro del marco del DI, en donde se observa cómo los Estados miembros, acordaron por considerarlo beneficioso para sus intereses y para garantizar su supervivencia en el escenario internacional -los cuales hacía pocos años habían padecido las invasiones napoleónicasceder parcelas de soberanía en lo que a seguridad exterior e interior respecta en favor la Confederación Germánica, pero manteniendo su soberanía o autonomía en otras materias, con este caso se comprueba lo antes desarrollado en la presente investigación, en que el tratado constitutivo es la materialización del pacto social internacional, receptora de la soberanía de los Estados para los campos y alcances que estos de forma libre y soberana, por considerarla beneficioso para sus intereses, cederán sus competencias en los campos que consideren pertinentes en un OS que será finalmente quien actúe e imponga el derecho creado sobre sus miembros constitutivos.

Seguidamente, tras la constitución de la Confederación Germánica, y consolidado el primer pilar sociológico, se dio paso al segundo pilar, el económico.

En 1815, las murallas del sistema aduanero napoleónico fueron derribadas y la nueva confederación germánica no se preocupó demasiado para edificarlas de nuevo. El mercado alemán se encontró así literalmente expuesto a todas las tempestades, fue una invasión de productos manufacturados, procedentes sobre 
todo de los stocks que Inglaterra había ido acumulando los años precedentes (Ayçoberry, 1988, p. 45).

Producto de esta situación, es que se observa cómo Prusia, a través del sistema de aduanas buscaría revertir esta situación y consolidarse como centro de integración económico de la Confederación.

La primera etapa consiste en unificar las provincias prusiana, separadas unas de otras por sesenta aranceles diferentes, quedando las del oeste abiertas al extranjero. En 1816 se abolieron todas las tasas sobre la circulación interior. En 1818 se fija un arancel uniforme en la frontera; pero los derechos de aduana continúan siendo moderados y, por otra parte, proporcionales al peso de las mercancías importadas, lo que satisface muy poco a los fabricantes, cuya materia se les encarece sin que la competencia británica sobre los productos acabados se vea muy afectada por ello (Ayçoberry, 1988, p. 46).

Por otra parte, Prusia gravaba todas las mercancías de tránsito con un arancel bastante elevado, encontrándose un formidable "garrote” económico y político, destinado a los otros Estados alemanes, los cuales comparaban al rey de Prusia como un "Barón saqueador" de la Edad Media y reclamaban a la Dieta ponga una política aduanera ciertamente alemana (Ayçoberry, 1988, p. 46). Estas medidas tan duras por parte de Prusia se entienden porque a través de estas medidas, estaba generando las condiciones necesarias para que Estados de menor envergadura y peso político-económico, sintieran la necesidad de una integración no solo defensiva, sino económica para que no se viera perjudicada la industria nacional de cada Estado. Por ello,

De 1819 a 1828 Prusia propuso o impuso tratados bilaterales a una serie de estados, en primer lugar, minúsculos y luego pequeños y medianos. Se trata a veces de enclaves dentro de su territorio, cuya desaparición acortaba las líneas aduaneras, o a veces de etapas situadas en una gran vía comercial, como los tres ducados de Anhalt, a un lado y otro del Elba; a veces incluso de economías concurrentes (Hesse-Darmstadt), pero cuya integración demostraba a la opinión pública que Prusia sabía aceptar sacrificios. Los instrumentos fueron brutales: bloqueo de Anhalt durante tres años, corte total entre el norte y el sur, lo que acentúo la gravedad del marasmo general. Pero la victoria fue generosa: los gravámenes y los 
ingresos de las aduanas fueron repartidos a prorrata entre la población, manteniendo el vencido el derecho de veto sobre las decisiones comunes (Ayçoberry, 1988, p. 47).

Un detalle que llama mucho la atención de esta integración económica-comercial, es que, si bien al interior de la Zollverein se comienza a articular un libre comercio, las medidas de proteccionismo moderado con respecto al extranjero se mantuvieron firmes. Firmándose con 25 Estados (lo cual significo uniformizar un mercado de cerca de 26 millones de habitantes) los que unificaron sus sistemas aduaneros respecto al exterior y lo abolieron en sus relaciones recíprocas con los demás estados germánicos.

No obstante, todavía no se puede hablar de una unificación plena, toda vez que a pesar de la ya existir un OS tal como la Confederación Germánica, todavía seguía existiendo la individualidad de estos actores, una unión todavía efímera que veía en sus grandes aliados, Prusia y Austria, a los actores de pesos sobre los cuales orbitar y en quienes finalmente apoyarse; no obstante, el hecho de existir dos actores de peso como los antes señalados, de alguna forma generó disputas y competencias el interior de este OS por quien era finalmente el Estado que lideraba el proceso integrador y el que imponía sus intereses y visión del mismo sobre los demás Estados. Además, había un detalle a tener en consideración muy importante, que, si bien existía una homogeneidad cultural (idioma, historia, costumbres, tradiciones, así como un sentimiento de nacionalidad común) no existía una homogeneidad religiosa, toda vez que el norte era luterano, liderado por Prusia, mientras que el sur católico, siendo Austria la potencia católica germánica por excelencia.

Si a lo largo de la presente investigación se sostuvo la importancia de la homogeneidad cultural y religiosa como pilares de integración, ¿cómo frente a esta divergencia entre un norte luterano y un sur católico, se pudo constituir este proceso de integración?

Porque ambas creencias, la católica y la luterana, son ramas o vertientes de una misma religión, la cristiana, cuya unidad e integridad se mantuvo incólume desde su fundación hasta la reforma protestante que dividió al mundo cristiano europeo continental entre los seguidores del Papa y Roma (católicos) y los que apostaban por una iglesia nacional, independiente del poder de la Curia y que respondiera a los intereses nacionales y políticos 
de su propio rey (luteranos). Si bien, se dieron divergencias y hasta ciertos dogmas de fe (como la virginidad de María, por citar un ejemplo), ambos parten del ejemplo y enseñanzas de Cristo, teniendo a la larga una misma cosmovisión, puesto que tienen una moral común, con matices y pequeñas diferencias en ciertos puntos, pero común al final de cuentas, siendo esta moral común la que de alguna manera terminó por facilitar la unión entre estas dos diferentes ramas. Además, es importante recalcar que dentro de esa visión "espiritual” que se mención en esta investigación con Hegel y Smend, el punto fuerte de unidad entre los Estados germánicos, se basó en esa visión o sentimiento común de la nacionalidad alemana, la nación alemana, la cual se hacía real a través del idioma, las costumbres y la historia común que, a pesar de la pluralidad de reinos y estados de menor índole, los terminaba por unir y relacionar; ello sin contar a su vez con el deseo y aspiración del pueblo alemán en sí por integrarse en una gran Alemania.

Proceso que encontró en el DI la herramienta jurídica para materializarlo a lo largo del tiempo, proceso que si bien en determinados momentos tuvo episodios de enfrentamientos al interior de la Confederación (la Guerra de las Siete Semanas entre Prusia y Austria), estos se dieron más que nada por intereses de gobierno, mas no por sentimientos encontrados entre los pueblos de cada Estado. Es importante recordar, que Austria finalmente termina relegada de este proceso de unidad, por justamente no ser puramente alemán, sino ser un imperio plurinacional, que, por justamente no tener una homogeneidad cultural, era visto como un impedimento para formar la gran alemana, toda vez que esta era entendida como la patria de y para los alemanes.

Finalmente, cuando se logró garantizar la supervivencia de los Estados menores girando a través de la órbita de un gran actor internacional como lo fue Prusia, potencia militar europea de su época, así como lograr el desarrollo de la producción alemana gracias a las medidas proteccionistas prusianas dentro de la Confederación (que terminaron al final por hacerlo años después un gran competidor industrial de otras potencias tales como Francia o Gran Bretaña al momento de constituirse el II Reich), se terminó consolidando la Zollverein, la visión de productiva individual de cada Estado alemán, terminó siendo relegada por una visión más colectiva, más de la “Confederación”, porque esta terminaba siendo más rentable y beneficioso para todos. El DI, terminó dando la unidad y la paz dentro del espacio 
germánico, así como la seguridad de sus miembros hacia el exterior, se dio la prosperidady bienestar económico que todo Estado persigue, siendo la cooperación y la integración entre ellos el medio y mecanismo por el cual se logró dicho objetivo. Por ello y tras la agresión Francesa, es que finalmente el sentimiento nacional alemán termina por constituir un nuevo Estado, Alemania, el II Reich, teniendo como sus cimientos todo el aparto económico, legal y militar que se logró conformar gracias al DI con la Confederación Germánica, por ello es que cuando se convergen los intereses geopolíticos, se conduce el proceso integrador de manera eficiente en su cuatro etapas (Zona de Libre Comercio, Unión Aduanera, Mercado Común y Unión Económica) y las sociedades se esmeran por construir dichos procesos alineándose en los cuatro pilares sociológicos de integración (Seguridad - Supervivencia, Bienestar, Religión y Cultura), podemos hablar del DI como un Derecho que en su máxima instancia y plenitud puede constituir nuevos Estados, tal como lo demostró el caso de la Unificación Alemana. 


\section{Bibliografía}

Acosta Estévez, J. B. (Abril de 2004). El derecho internacional, el derecho comunitario europeo y el proyecto de constitución europea. Jean Monnet/Robert Schuman Paper Series, IV(3), 1-48.

Aguilera Barchet, B. (2014). Entre Estado y nación Sociedad, poder y derecho, de la prehistoria a la integración Europea. Madrid: Instituto de Estudios Jurídicos Internacionales.

Alighieri, D. (1996). Dante: Monarchy. (P. Shaw, Ed.) Cambridge: Cambridge University Press.

Álvarez Londoño, L. F. (2007). Derecho Internacional Público (Cuarta ed.). Bogotá: Pontificia Universidad Javeriana.

Andrew, E. (2011). Jean Bodin on Sovereignty. Republics of Letters: A Journal for the Study of Knowledge, Politics, and the Arts, 2, 75-84.

Axelrod, R. (1994). Ética Nicomaquea. México: Porrúa.

Ayçoberry, P. (1988). La Unidad Alemana. Barcelona: oikos-tau, s. a. .

Balassa, B. (1964). Teoría de la integración económica. Ciudad de Mexico: Uteha.

Barbe, E. (1987). El papel del Realismo en las Relaciones Internacionales. Revista de Estudios Políticos (Nueva Epoca)(57).

Biquez, Y., Pereyra, A. M., Estevez, L., Curbelo, P., Brunetto, M. J., \& Bas, M. (s.f.). Universidad de la República - Uruguay. Obtenido de Facultad de Derecho Abogacía. Notariado Derecho de la Integración: wold.fder.edu.uy/material/pereyra-ana_derechointegración.pdf

Bloch, M. (1995). Introducción a la Historia. México D. F. : Fondo de Cultura Económica.

Bodin, J. (2006). Los seis libros de la República. (P. Bravo Gala, Ed.) Madrid: Tecnos.

Carruitero Lecca, F., Gutíerrez Canales, M. R., \& Torres Lobato, G. (2005). La Constitución peruana y la seguridad jurídica del Derecho de la Integración Andina. Lima: Studio Editores.

Clark, C. (2006). Iron Kingdom: The Rise and Fall of Prussia, 1600-1947. Massachusetts: Harvard University Press .

De Vega, P. (1998). Mundialización y Derecho Constitucional: La crisis del principio democrático en el constitucionalismo actual. Revista de Estudios Políticos(100), 28. 
Diez de Velasco, M. (1963). Curso de Derecho Internacional Público (Vol. I). Madrid: Tecnos. Donskis, L. (Ed.). (2011). Niccolò Machiavelli: History, Power, and Virtue. Amsterdam-New York: Rodopi.

Dromi, R., Ekmekdjian, M. A., \& Rivera, J. C. (1996). Derecho Comunitario Sistemas de Integracion, Regimen del Mercosur. Buenos Aires: Ediciones Ciudad Argentina.

Falcón, R. (2012). Integración y Derecho en la Unión Europea. Un recorrido por la historia, las normas y la evolución institucional de 1957 a 2004. Saarbrücken: Editorial Académica Española.

Fernandez Esteban, M. L. (1994). La noción de Constitución europea en la jurisprudencia del Tribunal de Justicia de las Comunidades Europeas. Revista Española de Derecho Constitucional, 241.

Garcés Ávalos, G. (2016). De Augsburgo a Westfalia: El nacimiento del Derecho Internacional Moderno. (Tesis de Pre-Grado). Lima: Universidad de Lima.

García Herrera, M. A. (1998). Rigidez Constitucional y Estado Social. Cuadernos de derecho judicial(13), 33-80.

García Roca, J. F. (1988). Sobre La Teoría Constitucional de Rudolf Smend (A propósito del libro de Pablo Lucas Verdú La Lucha contra el positivismo jurídico en la República de Weimar). Revista de Estudios Políticos (Nueva Epoca), 269-276.

Guerrero Mayorga, O. (2005). Instituto de Investigaciones Jurídicas - UNAM. Obtenido de Anuario de Derecho Constitucional Latinoamericano: https://revistascolaboracion.juridicas.unam.mx/index.php/anuario-derechoconstitucional/article/view/30283/27334

Haberler, G. (1964). "Integration and growth in the World economy in historical". American economic review, LIV.

Hegel, G. W. (2016). La Fenomenologia del espiritu. Createspace Independent Publishing Platform.

Henry, A. (1904). The De Monarchia of Dante Alighieri. Boston and New York: Houghton, Mifflin and Company.

Hobbes, T. (1940). Leviatán o la materia, forma y poder de una república eclesiastica y civil. (M. Sánchez Sarto, Trad.) México : Fondo de Cultura Económica.

Hobbes, T. (2003). Leviatán. Buenos Aires: Losada.

Huntington, S. (2001). ¿Choque de Civilizaciones? Teorema, XX/1-2, 125-48. 
Jiménez González, C. (julio de 2009). Teoría de las Relaciones Internacionales. Obtenido de Teoría de las Relaciones Internacionales: https://teoriarelacionesinternacionales.files.wordpress.com/2009/07/idealismo1.pdf

Kant, I. (1985). Paz Perpetua. Madrid: Tecnos.

Kelsen, H. (1995). Teoría General del Derecho y del Estado. (E. García Máynes, Trad.) México: Universidad Autónoma de México.

Kelsen, H. (2009). El Estado como integración. Una controversia como principio (Segunda Edición ed.). Madrid: EDITORIAL TECNOS (GRUPO ANAYA, S.A.).

Koskenniemi, M. (2005). From Apology to Utopia - The Structure of International Legal Argument". Cambridge: Cambridge University Press.

Landa Arroyo, C. (27 de abril de 2017). Academia de la Magistratura. Obtenido de http://catalogo.amag.edu.pe/web/html/servicios/archivos_articulos/2001/La_aplic_tratad os_internac.htm

Lauterpacht, H. (1970). International Law: Being the collected papers of Hersch Lauterpacht (Vol. I). (E. Lauterpacht, Ed.) Cambridge: Cambridge University Press.

Lucas Verdú, P. (1987). La lucha contra el positivismo jurídico en la República de Weimar. La teoría constitucional de Rudolf Smend. Madrid: Tecnos.

Maestre, A. (2007). El liberalismo de Tocqueville: Libertad, Democracia y Religión. En E. N. (editor), Alexis de Tocqueville. Libertad, igualdad, despotismo (pág. 316). Madrid: FAES.

Mammarella, G., \& Cacace, P. (1998). Storia e poliltica dell 'Unione Europea. Bari: Laterza. Maquiavelo, N. (1978). El príncipe. (H. J. Morgenthau, Trad.) México : Porrúa.

Maritain, J. (2002). El hombre y el Estado. Madrid: Ediciones Encuentro.

Molina del Pozo, C. F. (1990). Manual de Derecho de la Comunidad Europea . Madrid: Trivium.

Moorhead, T. (2012). European Union Law as International Law. European Journal of Legal Studies, $V, 125-144$.

Moradiellos, E. (1994). El oficio de historiador. Madrid : Siglo XXI Editores.

Novak Talavera, F. (2003). La Comunidad Andina y su ordenamiento jurídico. En A. R. Brewer Carías, J. Castro Bemieri, G. Cuadra Carrasco, A. Fairlie Reinoso, A. Falla, C. GuzmánBarrón, ... L. Vinatea Recoba, Derecho Comunitario Andino (págs. 57-58). Lima: Fondo Editorial de la Universidad Católica del Perú. 
Novak Talavera, F., \& García-Corrochano Moyano, L. (2000). Derecho Internacional Público.

Tomo I: Introducción y Fuentes. Lima: Fondo Editorial de la Pontificia Universidad

Católica del Perú e Instituto de Estudios Internacionales.

Oppenheim, L. (1961). Tratado de Derecho Internacional Público (Vol. I). Barcelona: Bosch,

Casa Editorial.

Ortiz Ahlf, L. (2003). Derecho Comunitario y Derecho Internacional. Revista de Derecho de la Unión Europea $N^{o} 4(4), 13-26$.

Petit Primera, J. G. (2014). La Teoría Económica de la Integración y sus Principios

Fundamentales. Revista Venezolana de Análisis de Coyuntura, XX(1), 137-162.

Plata López, L. C., \& Yepes Ceballos, D. (2009). NATURALEZA JURÍDICA DE LAS

NORMAS COMUNITARIAS ANDINAS. Revista de Derecho $N^{o} 31,196-223$.

Ramírez Bacca, R. (2010). Introducción teórica y práctica a la investigación histórica. Guía

para historiar en las ciencias sociales. Medellín: Universidad Nacional de Colombia.

Ramírez Echeverri, J. D. (2010). Thomas Hobbes y el Estado absoluto: del Estado de razón al

Estado de terror. Medellín: Universidad de Antioquía.

Ramos-Oliveira, A. (1973). Historia social y política de Alemania (Tercera ed.). México DF,

México: Fondo de Cultura Económica.

Real Academia Española. (01 de Octubre de 2016). Diccionario de la Lengua Española.

Obtenido de https://es.oxforddictionaries.com/definicion/historia

Reale, M. (1988). Introducción al Derecho. Madrid: Pirámide.

Requeijo, J. (202). Economía Mundial. Un análisis entre dos siglos. Madrid: McGraw-Hill.

Restrepo Abondano, I. (1989). Estudio Preliminar e Introducciones. En Aristóteles, Politeia (La

Política) (págs. 65-96). Bogotá: Publicaciones del Instituto Caro y Cuervo LXXXIV.

Robles Morchón, G. (1996). Elementos del Derecho Comunitario. Madrid: MAPFRE, S.A.

Rodríguez Carrión, A. J. (2006). Lecciones de Derecho Internacional Público (Sexta ed.).

Madrid: Tecnos.

Rostworowski, M. (2013). Historia del Tahuantinsuyu (Segunda edición ed.). Lima: Instituto de

Estudios Peruanos.

Sabine, G. H. (1994). História de la Teoría Política. México : FCE.

SENTENCIA DEL TRIBUNAL CONSTITUCIONAL EXP. N. ${ }^{\circ} 1277-99-A C / T C$, EXP. N. ${ }^{\circ}$

1277-99-AC/TC (TRIBUNAL CONSTITUCIONAL 1999).

Shennan, M. (1995). The Rise of Brandenburg-Prusia. London: Routledge. 
Smend, R. (1985). Constitución y Derecho Constitucional. Madrid: Centro de Estudios Constitucionales.

Smith, A. (2001). La riqueza de las naciones. Madrid: Alianza Editorial.

Snyder, L. L. (Ed.). (1958). Documents of German History. New Brunswick, Ney Jersey: Rutgers University Press.

Sobrino Heredia, J. M. (2001). Algunas Consideraciones en Torno a las Nociones de Integración y de Supranacionalidad. Anuario da Facultade de Dereito da Universidade da Coruña(5), 853-870. Obtenido de Fundación Dialnet: https://dialnet.unirioja.es/servlet/articulo?codigo $=1217507$

Sobrino Heredia, J. M. (2001). El Derecho de la Integración. Themis(42), 21.

Spiazzi, R. (2004). Santo Tomas de Aquino: Biografía documentada de un hombre bueno, inteligente, verdaderamente grande. Madrid: Edibesa.

Suárez, E. E. (2004). Introducción al Derecho. Santa Fe: Universidad Nacional del Litoral.

Tajadura Tejada, J. (2001). La crisis de la Constitución en el proceso de Integración Europea. La crisis de la Constitución en el proceso de Integración Europea, (pág. 40). Ávila.

Tamanes, R. (1990). Estructura económica internacional. Madrid: Alianza Editorial.

Toranzo, M. V. (1987). Introducción al estudio del derecho. México DF: Porrúa.

Universidad Nacional Autónoma de México. (10 de Octubre de 2016). Portal Académico de la Universidad Nacional Autónoma de México. Obtenido de Portal Académico de la Universidad Nacional Autónoma de México: http://portalacademico.cch.unam.mx/alumno/historiauniversal1/unidad1/historiaInterpre taciones/corrientesHistoriograficas

University of Oxford. (01 de Octubre de 2016). Oxford Dicctionary. Obtenido de https://es.oxforddictionaries.com/definicion/historia

Verdross, A. (1978). Derecho Internacional Público (Sexta ed.). Madrid: Aguilar.

Villamor Morgan-Evans, L. (1999). Los límites de la soberanía del Estado en un contexto de configuración supranacional. Anuario de la Facultad de Derecho, $N^{o} 17$, 633-639.

Voltes, P. (2004). Bismarck. Madrid: Palabra.

Voltes, P. (2006). Federico "El grande" de Prusia. Madrid: Ediciones Palabra S.A.

von Bismarck, O. (1898). Pensamientos y Recuerdos de Otto, Príncipe de Bismarck. (H. Kohl, Ed.) New York y Stuttgart: Desván de Hanta.

Wilson, J. F. (2008). Royal Monarchy: ‘Absolute’ Sovereignty in Jean Bodin's Six Books of the 
Republic. Interpretation: a Journal of Political Philosophy, 35 , 241-264.

Zegarra Mulánovich, Á. (2009). Descubrir el Derecho: Las nociones elementales del Derecho

Privado y del Derecho Público explicadas en forma sistemática. Lima: Palestra

Editores.

Zelada Castedo, A. (1989). Derecho de la Integración Económica Regional. Buenos Aires:

Ediciones Depalma.

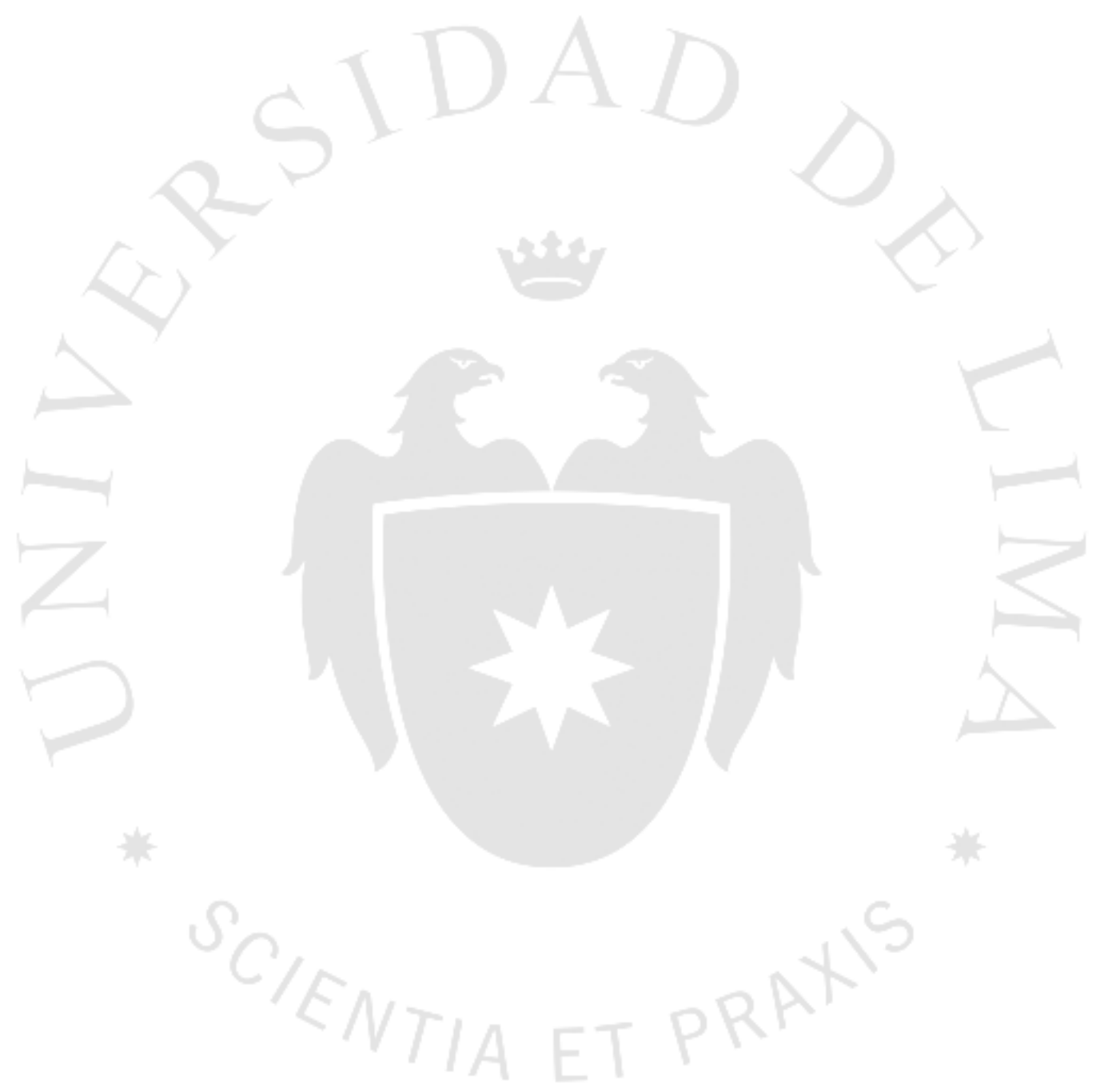

